\title{
Conflict, Disaster and Changing Gender Roles in Nepal: Women's Everyday Experiences
}

Luna K.C. 


\section{Thesis committee}

\section{Promotor}

Prof. Dr D.J.M. Hilhorst

Professor of Humanitarian Aid and Reconstruction

Institute of Social Studies, Erasmus University, Rotterdam

\section{Co-promotors}

Dr G. van der Haar

Assistant Professor, Sociology of Development and Change Group

Wageningen University \& Research

Prof. Dr L. Campbell

Professor and Chair

Department of Gender, Sexuality, and Women's Studies

Simon Fraser University, Burnaby, Canada

\section{Other members}

Prof. Dr BB Bock, Wageningen University \& Research

Dr F.K. Boersma, V U Amsterdam

Dr R. Kurian, Erasmus University, Rotterdam

Dr S. Bradshaw, Middlesex University, UK

This research was conducted under the auspices of the Graduate School Wageningen School of Social Sciences (WASS) 


\title{
Conflict, Disaster and Changing Gender Roles in Nepal: Women's Everyday Experiences
}

\author{
Luna K.C.
}

Thesis

submitted in fulfilment of the requirements for the degree of doctor at Wageningen University

by the authority of the Rector Magnificus,

Prof. Dr A.P.J. Mol, in the presence of the

Thesis Committee appointed by the Academic Board

to be defended in public

on Wednesday 16 January 2019

at 1.30 p.m. in the Aula. 
Luna K.C.

Conflict, Disaster and Changing Gender Roles in Nepal: Women's Everyday Experiences 183 Pages.

$\mathrm{PhD}$ thesis, Wageningen University \& Research, Wageningen, the Netherlands (2019) With references, with summaries in English and Dutch

ISBN: 978-94-6343-389-1

DOI: https://doi.org/10.18174/466013 
Dedicated to:

Women Ex-Combatants and Non-Combatants (Didi/Bahini) of Nepal and my parents Neelam Thapa K.C. and Ram K.C. 


\section{Acknowledgements}

This Ph.D. journey would not have been possible without the love, motivation and support of some wonderful people, and organizations. First and foremost, I whole heartedly thank my academic supervisors: Gemma Van Der Haar, Dorothea Hilhorst and Lara Campbell.

To Dear Gemma: I am fortunate to have 'you' as my daily supervisor. Your academic excellence, exceptional guiding and positive energy 'you can do that' kept me inspired throughout this journey. You never hesitated to read/comment my 'drafts' which at first did not make sense. You encouraged me to rethink/rewrite and without hurry waited until I cameup with a solid argument. Your critical insights and challenging questions have groomed me to become an independent researcher. You always managed time for me when I needed. Whenever, I went through difficult times you were always there to listen and advice. I also cherish the moments when you visited my field-work in February 2015; 'travelled by the local bus' to Chitwan, 'road blockade' on our way, 'auto-rickshaw ride' to the village to meet women, 'Rhino/Elephant watch' and many more.

To Dear Thea: You are truly dedicated mentor, not only for your tremendous academic support, but also for constantly believing in my work and allowing me to take this academic challenge. Your excellent academic leadership, encouraging attitude and caring nature always motivated me to stay tuned. Despite of your busy schedules you always accepted my skype requests, promptly read/comment my work and available to discuss/listen every-time I asked for. I still have a fresh memory of our meeting in March 2014 at 'Himalayan Java-Thamel' Kathmandu and having 'momo', which meant a lot to me. Whenever, I visit this place it recalls of you.

To Dear Lara: I am so glad to be supervised by you. Thank you very much for hosting me at SFU and making me a part of your team. I really learned a lot from the courses and the seminars offered at Department of Gender, Sexuality, and Women's Studies. This was a life-time experience. Your advice on both academic as well as on my career have been precious. You always welcomed me in your office also when I suddenly appeared without appointments. I appreciate all the support you provided, especially during the last stretch of my Ph.D. project and beyond. 
My heartfelt of thanks to Sangeeta Shrestha, my lifetime mentor. Your 'big heart' and unconditional support made possible to take off this journey. I always value your professional as well as personal suggestions and advice. I will forever treasure your friendship, love and care. Thanks again for connecting me with women non-combatants living around Kapan areas of Kathmandu, allowing me to use your office space, internet, and other materials during my Ph.D. field work, and beyond. I also would like to thank entire SLISHA team for all their support.

The next person I owe is Wendy Ömerköylu: You are a 'great manager' who never hesitated to respond about anything and at anytime. I would like to thank you for all your help you provided me during my stay in the Netherlands as well as in the field, otherwise life would have been much difficult. I enjoyed your company eating lunch, coffee breaks and chatting. Thanks, again for hosting such a memorable 'summer party' in the May of 2013 at your lovely house, including taking me for a lovely lake-tour and a boat ride.

My heartful of appreciation to all the women ex-combatants and non-combatants who happily shared with me their life-time experiences. Without their help and wiliness to speak to me my $\mathrm{Ph} . \mathrm{D}$. on this 'topic' would not have been possible. I value the hospitality and care they provided me in the field. I called them in Nepali language Didi and Bahini (elder and younger sisters). I dedicate this thesis to: Women ex-combatants and non-combatants (Didi Bahini). I admire their resilience and perseverance. I am thankful to Mr. Kedar Neupane for introducing me to his colleagues in the Ministry of Peace and Reconstruction-Nepal and helping me to conduct my field work. I also would like to thank the local leaders, individuals and organizations in Nepal who supported my Ph.D. field work.

My special thanks to my friends and colleagues at Humanitarian Aid and Reconstruction Special Group: Annisa Srikandini: Thank you very much for being a wonderful friend. Teddy Atim: Thanks for all your support and encouragement that kept me active till the end. I also would like to thank Rose Bashwira, Gloria Nguya, Claude Iguma, Gayathri Lokuge, Jose Diemel, Carolien Jacobs, Winnie W. Wairimu, and Aembe Bwimana for their friendship. My deep appreciation goes to the Sociology of Development and Change Group for hosting me in the team. Especial thanks to Aicha Makoui for assisting me with the last-hour administrative and logistics. 
I would like to thank Prof. Jennifer Marchbank and Dr. Tiffany Muller Myrdahl for reading my work, providing valuable suggestions, job search advise and many more. Heartful of thanks to Isha Sharma for being a good friend/sister. My gratitude to all my friends and colleagues at Department of Gender, Sexuality, and Women's Studies, Simon Fraser University for their care and support.

I am thankful to my parents: Neelam K.C. and Ram K.C. for their unconditional love and inspiration to follow my dreams. I am grateful to my family: Nishu, Rara, Jubin and Baba for your love, care and patience making my life colourful and meaningful.

To: Kalpana Giri, Saranue Sharma and Tripti Belbase, my best friends forever. I am fortunate to have you all in my life and thank you very much for your love and care. You guys are just awesome! Thanks, again yaar.

My special thanks to Binod Shahi, Nikesh Shrestha and Rara K.C. for sketching/coloring/ designing this thesis cover. Thanks to Ali Malcom and Dorothy Myers for editing this thesis.

Finally, I would like to thank Nuffic (Netherlands Fellowship Program) for their financial support that enable me to pursue this Ph.D. study. 


\section{Table of Contents}

Acknowledgements

Chapter 1: Introduction $\quad 1$

1.1 Women, Conflict and Post-Conflict Developments in Nepal 2

1.2 The Maoist War and its Aftermath 3

1.3 War, Disaster and Changing Gender Roles in Nepal 8

1.4 War, Disaster and Changing Gender Roles: What are the Questions? 11

1. 5 Research Questions 15

1.6 Studying Changing Gender Roles: Conceptual Framework 16

1.6.1 Sexual Division of Labour and Power Structure 17

1.6.2 Emancipatory Gender Ideology 18

$\begin{array}{ll}\text { 1.6.3 Structural Factors } & 20\end{array}$

1.6.4 The Role of Policy in Gender Role Change 21

1.7 Thesis Outline 23

1.8 References 25

Chapter 2: Methodology 31

2.1 Study Area $\quad 32$

2.2 Map of the Study Area $\quad 34$

2.3 Methodological Choices $\quad 34$

2.4 Finding Respondents and Negotiating Access 36

2.5 The Women's Profiles 38

2.6 In-depth Interviewing 39

2.7 Focus Group Discussion $\quad 41$

2.8 Participant Observation 41

2.9 Key Informant Interviews $\quad 42$

2.10 Positionality and Reflexivity 42

2.11 Ethical Considerations 46

2.12 Data Management and Analysis $\quad 47$

2.13 References $\quad 48$

Chapter 3: Changing Gender Role: Women's Livelihoods, Conflict and Post-Conflict Security in Nepal $\quad 51$

3.1 Introduction $\quad 53$

3.2 Conceptual Framework: Gender and Power 54 
3.3 Gender and Women Situation in Nepal: A Historical and Political Context

3.4 Research Methodology

3.5 Gender Division of Labour and Power: Experience of Women Ex-combatants and Non-

Combatants during Maoist Conflict in Nepal $\quad 58$

3.5.1 Women Ex-Combatants: Experiencing Gender Equality 58

3.5.2 Women Non-Combatants: Replacing Husbands and Fathers 61

3.5.3 Comparing Women Ex-combatants and Non-Combatants: Gender Division of

Labour and Power during Maoist Conflict in Nepal 64

3.6 Gender Division of Labour and Power: Experience of Women Ex-Combatants and Non-Combatants in Post-Conflict Nepal $\quad 64$

3.6.1 Women Ex-Combatants: Re-Integration and (Re-) Marginalization 65

3.6.2 Women Non-Combatants: Maintaining Economic Independence 69

3.6.3 Comparing Women Ex-combatants and Non-Combatants: Gender Division of

Labour and Power in Post Conflict Nepal 72

$\begin{array}{ll}3.7 \text { Conclusions } & 72\end{array}$

$\begin{array}{ll}3.8 \text { References } & 75\end{array}$

Chapter 4:Living Maoist Gender Ideology:Experiences of Women Ex-Combatants in Nepal 79

4.1 Introduction $\quad 81$

4.2 Background: Gender Discrimination and the Maoist Agenda $\quad 82$

4.3 Theoretical Framework $\quad 84$

4.3.1 Gender, Women and Armed Conflict $\quad 84$

4.3.2 Integrating Intersectionality $\quad 85$

4.4 Methodology 86

4.5 Maoist Ideology: The Prospect of Empowerment 87

4.6 Women Ex-Combatants' Experiences in the Maoist Conflict 90

4.7 Women Ex-Combatants' Experiences in The Aftermath of the Maoist War 93

$\begin{array}{ll}4.8 \text { Conclusions } & 98\end{array}$

$\begin{array}{ll}4.9 \text { References } & 100\end{array}$

Chapter 5: Everyday Realities of Reintegration: Experiences of Maoist 'Verified' Women

Ex- Combatants in the Aftermath of War in Nepal 105

$\begin{array}{ll}5.1 \text { Introduction } & 107\end{array}$

5.2 Understanding Disarmament, Demobilisation and Reintegration (DDR) from a Gender

$\begin{array}{ll}\text { Perspective } & 108\end{array}$

$\begin{array}{ll}5.3 \text { Methodology } & 111\end{array}$ 
5.4 Context: The Disarmament, Demobilisation and Reintegration Process in Nepal

5.4.1 Disarmament

5.4.2 Demobilization

5.4.3 Reintegration

5.5 Zooming in on the Reintegration Process: What did it Offer Verified Women ExCombatants?

5.6 Reintegration Experiences: Cash Compensation

5.7 Maoist Women Ex-Combatants: Visible in Conflict and Invisible in the Aftermath of Conflict

5.8 Family Matters: Re-Connection, Dis-Connection and the Everyday Realities of Reintegration

5.9 Conclusions

5.10 References

Chapter 6: Exploring Gendered Effects of the 2015 Earthquake in Nepal through Women's Eyes

6.1 Introduction

6.2 Conceptualising Gender Equality and Disasters

6.3 Gender Equality and Inequality in Nepal

6.4 Research Site and Methodology

6.5 Women's Stories of the Earthquake

6.6 Lived Experiences of Displacement

6.7 Role of Citizenship and Land Entitlement Documents in Accessing Relief

6.8 Livelihood Distress Beyond the Relief Phase

6.9 Changing Gender Roles and Relationships After the Earthquake

6.10 Conclusions

6.11 References

Chapter 7: Conclusion and Discussion

7.1 Introduction

7.2 General Reflection on this Thesis

7.3 Limitations and Future Implications

7.4 Policy Recommendations and Practice 
About the Author

Completed Training and Supervision Plan

Acknowledgements of Financial Support
Error! Bookmark not defined.

Error! Bookmark not defined.

181 
Chapter 1: Introduction 


\subsection{Women, Conflict and Post-Conflict Developments in Nepal}

One morning of November 2010 - I visited Hatti-Khor Cantonment, at Kawasoti, Nepal. I had set-an appointment to interview women combatants, while I was sitting on the open field waiting for them...I saw women with short hair cuts, commanding the military training... which I had never seen before... a Nepali woman performing such roles (Personal Observation, 2010, Nepal). This event was a turning point in thinking about gender role change.

This thesis is about women and changing gender roles in Nepal. My interest in this topic was triggered by my observations of female ex-combatants, a few years after the war ended. They seemed so different from how women are traditionally seen in Nepal. What brought these changes about? And what would happen to these women in post-conflict Nepal? In particular, this thesis looks at how women experienced changes brought about by the Maoist conflict (1996-2006) and the ensuing peace process, focusing on changes to their roles and responsibilities and examining both economic and familial hardships as well as new opportunities. It then asks similar questions about women affected by the 2015 earthquake that occurred while the country was still struggling with post-conflict recovery.

I became interested in studying women's experiences of the Maoist conflict and post-conflict issues when I was doing my Master's thesis on 'Securing livelihoods: experience of former Maoist mother combatants with children in post-conflict Nepal' in 2011. I found a considerable knowledge gap concerning how Maoist women (ex-combatants and non- combatants) experienced gender-role transformation during the Maoist conflict, and what happened to such roles in the aftermath of the war. This then became the theme of my doctoral research. Studying the impact of disaster suggested itself half way through the process.

Although this thesis is primarily about the ways in which women (ex-combatants and noncombatants) experienced the Maoist conflict and the post-conflict period, later, when I was completing my field work in Nepal, on 25th April 2015, a 7.8 magnitude earthquake hit the country. I was severely affected by this earthquake, and while living in the temporary camp together with other women, I became interested in studying the impact of the earthquake upon women. Studying women's experiences during and after the earthquake allowed me to provide additional insights into the dynamics around gender that $\mathrm{I}$ had set out to research.

The Maoist armed conflict in Nepal has had a severe impact on women's everyday lives. The Maoist struggle incorporated a strong agenda for the emancipation of women and successfully 
recruited women combatants into its ranks (Gautam et al. 2001; Parvati 2003). At the same time, many women who stayed away from the war (non-combatants) became heads of households as their husbands were killed or displaced. Both categories of women assumed new roles and responsibilities that cut across existing divisions of labour between men and women in Nepal. Likewise, the earthquake forced women to take up roles earlier reserved for men.

Both the conflict and the earthquake provide an opportunity to examine the ways in which women deal with rapid shifts in gender roles in a context where patriarchal gender patterns have prevailed. This thesis follows these shifts in gender roles in the aftermath of crisis and asks whether they persist once 'normality' returns and whether traditional role divisions can change in a fundamental, structural way. It takes women's everyday experiences as a starting point.

\subsection{The Maoist War and its Aftermath}

This thesis documents how women have experienced the Maoist conflict and its aftermath, and also covers the impact of the 2015 earthquake. To set the scene for later chapters, this section outlines the main events and impacts of the war and the main post-conflict developments, including the earthquake, and suggests what these processes meant for women.

The War

The communist party of $\mathrm{Nepal}^{1}$ (commonly known as a Maoist) led civil war in Nepal-also called as The People's War - lasted from 1996 to 2006. The Maoist Party sought to end the monarchic system that had been in place for 240 years and, in its place, establish a People's Republic (Upreti and Böker 2010; Thapa 2003; Thapa and Sharma 2009). The conflict formally started in February 1996 as the Communist Party of Nepal (Maoist), operating as the United People's Front of Nepal, declared the so-called 'People's War' (Jana Andolan). It formally ended with the Comprehensive Peace Accord of 21 November 2006 (NIPS 2013).

The conflict involved intense violence resulting in high numbers of casualties, torture, enforced disappearance, and sexual violence. The war claimed more than 13,000 lives, and as a result of the ongoing conflict, at least 200,000 people were displaced (Hamal 2007; Singh et al. 2007).

\footnotetext{
${ }^{1}$ Henceforth the Communist party of Nepal (CPN) is called 'Maoist party' in this entire thesis.
} 
A total of 1,378 people disappeared during the war and their identities are still unknown (UN OHCHR 2012). In 2003 and 2004, Nepal had the highest number of disappearances in the world (Nepal Monitor 2011). The Government security forces and the Communist Party of Nepal (Maoists) were involved in human rights violations throughout the country (UN OHCHR 2012). Furthermore, the conflict had an adverse impact on various sectors of the economy and the institutions: agriculture, trade and commerce, education, health, communication, and transportation. It has also affected socio-economic, cultural and religious aspects of people's lives (Hamal 2007; Thapa 2003). Local people suffered from a twofold threat from both the Maoist insurgence and the Government security officials (Hamal 2007; UN OHCHR 2012).

The violent conflict affected Nepalese women in various ways. Many women experienced family separation as men fled from the villages in fear of execution, left for military duty, or became involved in the Maoist insurgency. Sometimes this separation was permanent, when husbands, fathers, and sons were killed in the war (Basnet 2005; Hamal 2007). Most of the people who were killed, disappeared or disabled in the war were men (ibid). The burden of taking care of households, elderly people, and working in agriculture disproportionately shifted to women (Sharma and Prasai 2004; Gautam et al. 2001; Hamal 2007).

The population suffered severely during the conflict in part because the war was waged in close contact with civilians. The Maoists adopted the strategy and tactics of a 'protracted people's war'. They established base areas in the most rural and remote areas, with the aim of eventually moving to the urban areas and seizing power (Karki and Seddon 2003; Lawoti and Pahari 2009). The Government of Nepal responded with military operations to crush the insurgency in the Maoist stronghold areas (Karki and Seddon 2003, p.23). These operations were very violent: Many innocent people were accused of being Maoist, villagers were arrested, illtreated, tortured, and killed randomly (ibid). These actions resulted in a substantial proportion of the local people making common cause with the Maoists and the middle-west of Nepal was effectively confirmed as the Maoist heartland (ibid). From 1999 to 2001, Maoist military activities were intensified and scaled up, to the point where the Maoists claimed that there were only nine (out of a total of 75) districts that they did not have under their direct influence (ibid).

Peace talks between the Maoists and the Government of Nepal started in 2001 but suffered several set backs until the mainstream parties rallied behind the Maoists (Thapa 2003; Einsiedel, Malone and Pradhan 2012). After an unprecedented 19 days, a peaceful mass 
movement named Jan Aandolan II (People's Movement II), the Monarchy was overthrown, and the country was declared a federal democratic republic on 28 May 2008 with the Maoists emerging as the largest party in the constituent assembly.

\section{The Maoist Agenda}

The Maoist 'People's War' had three fundamental objectives: to overthrow the authoritarian and capitalist class and state system, to uproot feudalism, and to drive out imperialist (Monarchy) forces (Karki and Seddon 2003, p.30). A key text in understanding the Maoist agenda is the Maoist manifesto, the so-called '40-points' demand document that was presented to the parliament on 4 February 1996 (ibid). The document points out the inequality, exclusion, discrimination and hierarchy that were deeply rooted in the economic, social, political and cultural structure of Nepal, and offered a political plan to end such structures (Karki and Seddon 2003; Prachanda 2003; Pahari and Lawoti 2009; Hutt 2004; Thapa 2003). The document prioritises ending all forms of oppression and discrimination based on gender, as well as on class, caste or ethnicity.

The Maoist proposal resonated with the concerns of many common Nepali people especially in the remote rural areas. It appealed in particular to lower caste people, women, youth, poor peasants, ethnic minorities, and indigenous people who experienced oppression in their everyday lives. These included, for example, 44 percent of households (in the 1990s) were poor peasants who owned 0-0.05 hectares (Lawoti and Pahari 2009, p.8-10). Both women and men joined the Maoist war as combatants (Parvati 2003; Manchanda 2004). The conflict initially began from Rukum, Rolpla, Jarjarkot, Salyan, and Gorkha districts in the mid-western region of Nepal (Karki and Seddon 2003), from which it extended to other parts covering 66 out of 75 districts of Nepal.

\section{After War: Incomplete Transition}

Towards the end of the conflict, in 2006, as the peace negotiations between the Maoists and the Government of Nepal failed and the King dissolved the Parliament and reinstated direct rule (Lawoti and Pahari 2009), the mainstream parties formed the so-called Seven Party Alliance and rallied behind the Communist Party of Nepal (the Maoists) (Thapa 2003; Einsiedel, Malone and Pradhan 2012). They organised a mass movement, the Jan Andolan II 
(People's Movement II), which promoted an agenda for fundamental transformation of the state and society (Pyakurel 2008). The movement shook Nepal to the roots, effecting all the established structures - political, social and economic - and norms and value systems. Women, Janajati, Dalits, Madhesi, Muslims and other excluded groups participated widely in the movement with their own agendas for change (ibid). This movement had a deep impact on all aspects of national life, including the women's movement. The movement resulted in the end of the Monarchy and the installation of a constituent assembly to formulate a Democratic Constitution for a Federal Republic of Nepal (ibid). The CPN (Maoists) emerged as the largest party winning the majority of the seats in the Constituent Assembly (CA) elections in 2008. The country was declared federal, democratic, and republican on 28 May 2008, ending 240 years of monarchical rule.

After the peace agreement in 2006, Nepal faced multiple inter-related transitions: from war to peace, from autocracy to democracy, and from a centralised state to a decentralised state, (Einsiedel, Malone, and Pradhan 2012, p.361). Gender mainstreaming in policy was also high on the agenda, but confronted challenges while trying to put this into practice.

The transition from war to peace involved a complex Disarmament, Demobilisation and Reintegration (DDR) process. Especially the reintegration of the combatants turned-out to be very controversial because multiple political parties were engaged in the decision making for reintegration programming. Different parties had their own vested interests in this issue and building consensus among them posed a big challenge. The initial six-month timeframe for completing the DDR process (2007-2012) took nearly five years (Subedi 2014).

The transition from autocracy to democracy, and federalisation was also been complex and contested. For example, the new democratic constitution of 2015 still does not offer equal citizenship rights to women. Additionally, current federal structure does not provide clear-cut provision to reduce deeply ingrained discrimination along caste lines. At the same time, the CPN (Maoist) divided into 3 separate parties. The CPN supporters/cadres blamed top leaders for undermining the party's ideological commitment to bring equality and economic prosperity. They claimed that the party had expanded their connections with other powerful groups in society and had been politically co-opted at the expense of the interest of the party (Adhikari 2012). As a result, CPN (Maoist) lost the majority of seats in the 2017 constitution assembly elections. 
Gender mainstreaming and transition to a state that would protect women's rights became an important issue after the peace process, at least at the level of discourse. Nepal's New Constitution of 2015 reserves a quota of 33 percent of parliamentary seats for women (Upreti and Kolås 2016) and reserves 40 percent of seats for women in the local government bodies and mandates seats for dalit, ethnic minority and indigenous women (Limbu 2017). The government has introduced a policy of $25 \%$ land-tax cut, if that land is registered under woman's name. Similarly, the government set up a reward of Nepali Rupees 50,000 (USD 600) to a man who marries a widow (Ramnarain 2014). There are various quotas for women and girls in education, government jobs, health, communication and technical sectors. Women also occupied executive positions in Nepal. Although the State established multiple mechanisms for supporting gender equality and social inclusion, apparently the post-conflict development politics have been dominated by a few elite politicians from the ruling privileged caste and class. For instance, women's quotas were occupied by elite groups of women (who had better education, skills, trainings). As a result, the gender mainstreaming did not benefit non-elite women at the grassroots levels;

In the aftermath of the war, Nepal has moved from a centralized, unitary political system to a federal government system. This process began with the 2017 local elections, and this shift laid the groundwork for bottom-up development. In these local elections 14,352 (40\%) women were elected to local level government bodies in various political positions (Limbu 2018). This is the highest number of women holding public office in the country's history (ibid). This is a significant moment where the gender quotas directly open up political space for grassroots female political activism in Nepal. The impact of this brand-new administration upon the local people and the local government is yet to be seen.

Finally, the most prominent concern of the post-war transition period is stemming the flow of out-country migration. Because of the slow post-war recovery process and high unemployment, it has been estimated that 1600 women and men per day are migrating to foreign countries in search of employment (Shrestha 2018), and 31.4 percent of the country's Gross Domestic Product is dependent upon remittances from the workers abroad (ibid). It is still unclear how the country is going to sustain economic development and create adequate employment. 


\section{The 2015 Earthquake}

The earthquake of 25 April 2015 caused enormous human suffering, and also gave rise to new challenges in the still incomplete post-conflict transition. The earthquake delayed the country's first ever democratic constitution which was to be released in 2015. Women in particular had awaited this constitution which would include equal citizenship rights, property rights for women, and female quotas in the electoral bodies both at the national and local levels. Since 1999 there had been no elected local government bodies, and the earthquake pushed back the local elections as well, which were finally completed in January 2018.

The earthquake had an impact on women's everyday life in multiple ways. Many men were killed or disabled by the earthquake, whereas other men had migrated out of the country to work. Also, some men lost income/business in the earthquake. At this time, women were involved in rescuing their family, taking care of their children and elderly people, searching for food, accommodation, financial support, jobs, and health care.

Both during the Maoist war and in the aftermath of the earthquake, there was a similar trend with women taking up responsibilities that had been associated with the men in the household. Women were victims themselves and experienced the extra burden of taking charge of the households as their husbands were absent. This reality allowed women to expand and renegotiate their roles as wives and daughters. The trend was most prominent in the war years, in particular for those women who became active as combatants in the Maoist insurgency, supported by an agenda of (gender) equity. It was also reflected amongst women in the noncombatant population and with women who survived the earthquake.

\subsection{War, Disaster and Changing Gender Roles in Nepal}

This section presents the evidence to date on the impacts of war-time and post-war developments on women in Nepal and reflects on some of the core questions that emerge. It situates the study in relation to the literature on gender roles transformation in Nepal. 
Nepalese society is generally understood to be patriarchal, but the war seems to have changed this to some degree. It has been suggested that gender roles and relationships shifted during the war, both for women who joined the insurgency and those who stayed outside of it (Gautam et al. 2001; Manchanda, 2004). Considerable numbers of women were involved as combatants in the Maoist war (Gautam et al. 2001; Sharma and Prasai 2004). One estimate suggests women made up 30-40 percent of the Maoist fighting forces (Kattel 2003; Sharma and Prasai). The Maoist struggle had a strong message of emancipation for the oppressed rural population, members of the lower castes, and the women through whom it successfully recruited women combatants into its ranks (Gautam et al. 2001; Parvati 2003).

The women who stayed away from the war encountered numerous challenges as men disappeared, fled or were killed (Shakya 2009; Sharma and Prasai 2004; Hamal 2007). In the absence of men, women who stayed at home took up new roles: They performed social and economic responsibilities previously associated with men and began to participate more visibly in the public sphere. For example, they had increased access to a savings and credit groups, entered local politics, attended village and ward level meetings, searched for employment, or became self-employed entrepreneurs (Aguirre and Pietropaoli 2008; Moosa et al. 2013). This shows a shift away from traditional gender roles centred on the domestic household and farm work (Poudel and Carryer, 2000).

Do these shifts in roles by women amount to empowerment? On this point, there is considerable disagreement. Some feminist scholars argue that the Maoist movement afforded rural women an avenue for change and new options to escape narrowly confined gender roles and the exclusions they experienced in their daily lives (Manchanda 2004; Thapa 2003; Goswami 2015). This would explain why the Maoist movement attracted such high numbers of Nepalese women. Parvati, a high-level female leader in the Maoist insurgency, does not question women combatants' empowerment but attributes it primarily to the Maoists' efforts: it was only after the Maoist war started that grassroots women's voices, mainly those of rural women, began to be heard (Parvati 2003). 
Others have questioned if Maoist ideology was put into practice or was merely rhetorical. They point to studies that found Maoist women predominantly doing cooking, cleaning and rearing children rather than serving in combatant roles (Tamang 2009, p.75). Similarly, Pettigrew and Shneiderman (2004) argue that the extent to which janajati (indigenous) women who joined the Maoists were given meaningful roles is questionable. Other research has suggested, however, that women took up militarised roles within the insurgency, similar to their male peers. They participated in the guerilla training and were involved in military attacks, and some women even became commanders and led the battalions (K.C. 2011; Manchanda 2004).

Gautam, Banskota, and Manchanda (2001) make clear that the role shifts experienced by women are extensive and see them as empowering. They describe how 'in whole villages in the western hill district of Nepal, [Maoist strong hold areas], there are no men [either men became Maoist or left the village in fear of execution and abduction by the Maoist or government army, or disappear or killed]...In these villages without men, the women have been left to work with conflict, to negotiate with the police and the Maoists, and to ensure the survival and security of their families...It is women who have had to break tradition and take on the 'male' job of ploughing the land...'(p.92). Through this process women achieved empowerment and challenged the traditional understanding about women's roles (ibid, p.101102).

However, not all authors see these role shifts as empowering. Hamal (2007) and Shakya (2003) suggest that when the responsibilities of maintaining the family are placed onto the shoulders of women during wartime, they bear a disproportionate burden of poverty and suffering. One study found that while taking on additional burdens (in both private and public affairs), rural women suffered from a lack of education, skills, social safety, and faced psychological trauma (Shakya 2009, p.34). Another study by Yadav (2016), on the contrary, concludes that war widows were empowered while surviving independently in the Maoist war. It describes how widows - who traditionally are relegated to a marginalised position - started to fight back to redefine their identity and started to wear a red tika (tiny red mark stuck on the forehead as a symbol of womanhood), began to dress with colourful red sarees or even remarried - all things previously unheard of. In an earlier period, widows could only wear white sarees, no make-up, and had to remain unmarried. 
The literature on women and gender change in Nepal is still limited. This thesis aims to contribute to the existing scholarly literature by understanding these larger shifts from the women's own position and experience. It will examine what the Maoist conflict, and later the 2015 earthquake, meant to women, how they experienced the changes in their lives.

\section{Persisting Patriarchal Structures}

Although Nepal is rapidly transforming its social and political landscape, the patriarchal system is still pervasive. It is reflected in the Nepalese inheritance systems, family relations, the marriage system, and some legal systems (Greene 2015; Gurung 2018). For example, even after the declaration of the new constitution, women do not have equal citizenship rights, inheritance rights, or property rights as men. People are socialised in a way which, intentionally or unintentionally, accepts patriarchal norms. As a result, they often continue to uphold patriarchal practices in their everyday lives (Dhungana 2014; Greene 2015; Gurung 2018).

A key concern in this thesis is whether the greater social and economic responsibilities of Nepalese women acquired during the war were recognised and accommodated in a society in which male dominance remained the norm. It is unclear how the tension between the new roles and opportunities for women, and the limitations deriving from the patriarchal structures, has been resolved.

\subsection{War, Disaster and Changing Gender Roles: What are the Questions?}

It is now widely acknowledged that war has different effects on men and women. While women may be victimised in particular gendered ways, war may also open up possibilities for them to take up new roles and exercise more liberties. The literature provides ample evidence of how conflict might offer women the space to experience and negotiate change and develop their agency and resourcefulness (Arostegui 2013; Buvinic, Dasgupta, Casabonne, \& Verwimp, 2012; Grabska, 2013; Denov and Gervais 2006; 2013).

When women and girls join armed conflict, they often perform new roles and responsibilities earlier reserved for men, and in doing so break traditional norms around female behaviour (Shekhawat, 2015; El-Bushra 2003; Cohn 2013). A study in Liberia (Fuest 2008) and Eritrea (El-Bhusra 2003) noted that conflict expanded women's roles as they were directly involved in the armed struggle and successfully took-up commanding military roles equal to men. 
Traditional role divisions between men and women are thus bracketed (Shekhawat 2015; Azmi 2015).

It is not only women combatants who experience expansion of their roles; non-combatant women have similar experiences. As women need to survive the war in the absence of men, they take up new responsibilities as heads of household in the private as well as in the public sphere (Cohn 2013; Ramnarain 2014). El-Bhusra's (2003) study on Sudan, Angola, Mali and Uganda found that the war gave rise to rapid changes in gender roles at the household level (p.258). This turned out to increase women's decision-making, income generating opportunities and allowed them to acquire different ways of life and new skills. Likewise, Jacobson's (1999) research in Mozambique points out that when men flee from the war to towns and the capital, women cared for their dependents, and actively engaged in the public spheres of politics and found waged employment (p.180).

The effects of war on non-combatant women have been found to vary. Conflict may increase the insecurity for women and limit their movements. There is an increase in gender-based violence, for example, as women can no longer safely travel rural roads and access their fields or water points. It however may also increase societal acceptance of their new roles as heads of households, expanding their economic and political agency. El- Bushra's (2000) work in Northern Uganda, Rwanda, and Somalia suggests that married women who coped with the challenges of war unaided by their husbands experienced a significant increase of their selfdetermination (p.69-78), because women assert greater autonomy in decision making about marriages, children and sexual relationships (ibid p.73).

There is much debate in recent literature on whether wartime changes in gender roles continue or discontinue in the aftermath of the war. Important questions are whether women retain the new roles acquired during conflict, and how such changes effect their everyday relationships in the family and community (Afshar and Eade 2004; El-Bushra 2003; Cahn and Aoláin, 2009; Shekhawat 2015). The picture is not clear-cut. El-Bushra's (2003) work on Uganda, Mali, Sudan, Angola, and Somalia suggests that 'gendered power structures have changed because of conflict, though to a limited degree. Women's increased economic power... has sometimes enabled them to exert greater influence and become more involved, mainly within the household but in some cases also outside.' (p.259). But she also observed that, in spite of women's gains in terms of empowerment, the ideological foundations of gender relations have 
barely changed and may even have become further reinforced through conflict (p.264). Similarly, in Mozambique, when men fled from the war, the female population in rural areas was estimated to be 90 percent (Jacobson's 1999, p.179). In war time, women cared for both the households and outside affairs but in the aftermath were placed at the margins of the "real development' process (ibid, p.177-181).

Even where women have been accorded a larger change of role in the war, this has often not translated into political inclusion in the peace process and women face many disappointments on return to 'normality' (Shekhawat 2015, Enloe 2004; Rajasingham-Senanayake 2004; Azmi 2015). The scholarship on post-war settings provides enough evidence that, when peace time begins, women are intentionally and unintentionally left out of the post-conflict reconstruction process and are forced to take-up their earlier roles (Manchanda 2001; Goswami 2015; Shekhawat 2015). The post-conflict policy choices as well as sticky gender norms and persistent structural inequalities may produce a certain backlash to women's expanded roles and limit their everyday room for manoeuvre. A study by the UN on women reviewed 31 peace processes in 2014 and showed that only $4 \%$ of peace agreements had women as signatories (Mlinarević et al. 2015). There are also cases, where changes in policy are favourable to women such as in Rwanda, women acquired the right to own land as an outcome of post-genocide policy reformation (Jacobson 2013, p.233). Likewise, in Afghanistan and Iraq, gender quota increased women's participation in the parliament (Jacobson 2013). But still, in many ways in the post-war era, women are excluded.

The scholarship to date clearly demonstrates that conflict involves processes of gender role change but raises questions about how these changes carry over into the post-war setting. The degree to which change of gender roles is the case and the mechanisms at work are not yet well understood. Outcomes may vary with the nature of the war and women's wartime involvement, the nature of the peace-building process and with different categories of women. This thesis aims to contribute to this debate by conducting in-depth analysis of gender role change in Nepal. Nepal offers an excellent case given the high female participation in the Maoist insurgency, the large number of women-headed households facing the effects of war, and the emphasis on gender mainstreaming in the post-war peace process.

This thesis studies how gender roles changed during the Maoist war, and in the period after the war, for both women combatants and women non-combatants. It explores whether the new 
social and economic responsibilities and the public presence of women induced by the conflict persist in the post-war setting and with what implications for women.

Similar, questions about changing gender roles are relevant in the study of disasters. Like violent conflicts, disasters effect men and women differently and gender is one of the factors that shapes the way people view disasters and find space to respond and recover (Enarson and Fothergill 1998; Cupples 2007; Irshad, Mumtaz, and Levay 2012; Bradshaw 2013). As with military conflicts, there has been increasing scholarly interest in understanding women's agency during and after disasters, moving beyond an understanding of women as victims (Ruwanpura and Humphries 2004; Perera-mubarak 2013).

The growing body of literature about gender and disaster has shown how women fare in disaster, where they often play multiple roles and develop leadership skills in the time of crisis and beyond (Bradshaw 2001, 2013; Horton 2012; Enarson and Morrow 1998). There have been cases where disasters are seen to trigger changes in gender roles and relations. Bradshaw's (2001) study in Nicaragua has found that as women participated in the reconstruction projects and in individual household responses, this process changed gender roles and relationships (p.71). Another research in Sri Lanka shows that in the post-tsunami setting, when women received income generating training from NGOs, they successfully ran their business, mobilised their networks and performed manifold economic roles (Perera-mubarak 2013, p676-679).

Even though disasters might provide opportunities for women, this is not always the case. It has been suggested that post-disaster periods remain fully gendered, and often retain unequal gender norms and social inequality (Fothergill 1998; Bradshaw 2014). Therefore, the ways in which gender role transformation is carried over or retained, altered or rolled back, during and after crises is complex and dynamic (Hilhorst, Porter, and Gordon 2018).

Whereas we might theorise that, as in periods of conflict, gender norms and roles become more 'fluid' under the pressure of a disaster, little is known about what happens to gender roles in the rapidly changing conditions of crisis and in its aftermath. As women respond to the challenges of crisis, what shifts does this produce in their roles and responsibilities? Does this translate into more durable changes in gender roles? What are the factors that foster or limit such change, related to persistent gender inequalities and recovery policies? 
This research seeks to document how women in Nepal have experienced shifts in gender roles during and after the Maoist war and the 2015 earthquake and asks whether theses changes persist beyond the crisis episode and structurally change the position of women. It does so from the perspective of women who lived through these events and is based on their narratives. Until now, the literature on gender and disaster has paid little attention to gender effects of the earthquake in women's everyday lives in relation to their gender position and gender role change. Therefore, this thesis aims to address this knowledge gap by showing how women faced multiple gendered effects of the earthquake and how this how this process shifts in gender role in the wake of post-earthquake in Nepal.

The study relies on a conceptual framework that focuses on the sexual division of labour and power, the ideology of gender and women's empowerment during and after war, the role of structural factors that might condition gender transformation, and the role of gender bias in the policy.

\subsection{Research Questions}

The central question this thesis addresses is: How have women (ex-combatants, noncombatants and earthquake survivors) experienced shifts in their gender roles during the Maoist conflict and the disaster, and have those changes in gender roles been sustained in the aftermath of war and disaster? More particularly, the research asks what challenges women faced after the crisis ended and how did post-conflict and disaster programmes respond to women's needs in the post-conflict and disaster context in Nepal?

The central question is addressed by seeking answers to the following four sub-questions.

1. How have gender roles of women (ex-combatant, non-combatant) changed during the Maoist conflict, and what happened to those changed roles in the aftermath of the war in Nepal?

2. What challenges did women face in their everyday lives in the post-conflict era and how has gender role change shaped women's responses to these challenges?

3. How have the post conflict reintegration policies shaped the process of gender role change and women's everyday challenges? 
4. What challenges did women face in the wake of the post-earthquake period, and how were these related to their gender position? How did gender roles change in the time of the earthquake in Nepal?

To answer the above research questions, an ethnographic approach was adopted comprising indepth interviews, focus group discussions, key informant interviews, and participant observation in the Chitwan, Kathmandu and Lalitpur districts of Nepal. The study is influenced by a feminist methodology which centers on the everyday lived experiences of women (Fonow and Cook 1991; Ramazanoglu and Holland 2002). This method calls for researchers to understand women's lives deeply, undertaking interviews in an open, unstructured, reciprocal, and non-hierarchical way (ibid). As this thesis is grounded in women's everyday lives, utilising feminist methodology allowed me to arrange open and reciprocal interviews, where women were able to share their stories in the ways they felt comfortable. Maintaining non-hierarchical relationships helped to understand women's lives more closely and in-depth, and to highlight their voices.

\subsection{Studying Changing Gender Roles: Conceptual Framework}

This thesis is based on a social constructionist approach to gender which argues that gender is socially, culturally and historically specific rather than biologically or naturally fixed (Scott 1998; Kimmel 2000). It builds on the work of scholars who have criticized earlier sex role theories as inadequate in terms of explaining and understanding the complexities of gender (Chetwynd and Hartnett 1997; Kimmel 2000). Following a constructionist approach means seeing gender as fluid and changing over time and place, implying that gender roles and expectations are never stable but always open to contestation (Connell 1987; Radtke and Stam 1994; Foucault 1980; Butler 1990; Scott 1998).

If we agree that gender is open and flexible to contestation, then looking at what happens to gender in times of crisis becomes particularly important. Under conditions of conflict or disaster the social construction of gender tends to become more 'fluid' and we might expect bigger and faster changes than under normal conditions.

Below, I present the conceptual framework for the thesis. My study's overall objective is to understand how gender roles changed in war, post-war and disaster settings, and the 
sustainability of such changed roles in the aftermath of the crisis. I utilised Connell's theory as central to this thesis, particularly in Chapter 3 in which I conducted an in-depth analysis drawing upon this theory.

In Chapter 4, I applied an idea of gender ideology which describes women's individual motivation and commitment to the Maoist ideology (that had strong message of gender equality). Here, the gender ideology relates to Connell's framework, because when women were committed to the Maoist ideology and participated in the struggle, it became clear that the gender ideology (women's commitment) challenged traditional ways of performing sexual division of labour and power, thus promoting gender role change.

Connell's framework suggested that 'structural factors' are fundamental and determine the interplay between the sexual division of labour and power structure of the society (1987, p.92). In this thesis, I utilised the idea of 'structural factors' throughout to understand how 'structural factors' encourage and/or discourage the gender role change process.

In Chapter 5, and to lesser degree in Chapter 6, I examined how policy works to sustain gender role change. I relate this idea about 'role of policy' with Connell's framework because the policy is a gendered process, where sexual division of power and labour are largely involved.

\subsubsection{Sexual Division of Labour and Power Structure}

Connell's (1987) theory argues that gender is socially constructed and flexible and can be understood in terms of the structures of 'labour' and 'power' (p.91-111). She suggests that due to the division of labour and power structures gender relationships, gender roles, and gender orders are constructed and re-constructed in the societal context (ibid). She offers the following framework to understand this process: i) the sexual division of labour which describes gendered labour practices and differences in 'women/men's work' 'pay', 'positions' 'households' jobs' and 'public jobs'(private/public), and (ii) the division of power structures which is about authority, control and coercion and the hierarchies of institutions, domestic authority, sexual regulation and surveillance, and its contestation. She writes that power is relational and is a process of domination and resistance. At societal level, the labour and power are embedded through historical norms, family, class, religion, and other socio-political forces (Connell 1987, p.95-104). 
Connell describes the practice of labour such as the organisation of house work, childcare, paid and unpaid work, men's jobs, women's job discrimination in promotion, unequal wages and exchange (Connell 1987, p.97) and the practice of power, for example, through the hierarchy of institutions, domestic authority, sexual regulation and surveillance. Studying these elements, allowed us to see how gender is socially constructed, and how women and men in their everyday lives regulate the practice of gender, and how this affects gender role change process.

Drawing on Connell's theory, I investigated how gendered dynamics of labour and power changed or were upheld in times of war and peace. I examined how women ex-combatants experienced performing militarised roles in the war, how the division of labour was accommodated, whether the roles women performed were subordinate to men, and where these roles were equal to men's roles. For women non-combatants, I examined how they took over the public roles previously reserved for men and what types of new roles they assumed to survive the crisis of war. In the post-war setting, I examined how both categories of women (combatants and non-combatants) could or could not continue to exercise these new roles in their everyday lives, and how they experienced the translation of their war roles in public/private spheres during peace time.

To analyse the sexual division of power, this thesis examined how power is expressed in women's everyday lives (during the time of war and post-war era) including how women are able to influence the decision making in outside affairs and at the household level, how they negotiate and renegotiate their demands, and how are they able to bring their voices into their everyday lives.

\subsubsection{Emancipatory Gender Ideology}

Connell's theory clearly indicates that, due to the interplay between sexual division of labour and power structures, gender becomes 'flexible'. Given the context and in order to understand the ways in which women experience gender role change, I first investigated the role of ideological motivation in explaining women's engagement in the Maoist war, and secondly, how women are able to translate their ideological drive in the post-conflict period.

A growing body of literature on armed conflict has demonstrated that ideology is an important factor for an armed group because it binds them to a systematic set of ideas and allows them to 
create collective solidarity (Hilhorst 2001; Ugarriza and Craig 2012; San1'n \& Wood, 2014). Studies about war and gender have already revealed that armed struggles, as a part of ideology, integrate an agenda of gender equality and women's empowerment. This has been a powerful message which attracts women into their forces (Alison 2009; Azmi 2015; Shekhawat 2015; Kampwirth 2002; Rajasingham-Senanayake 2004). An example is the LTTE in Sri Lanka, which successfully recruited Tamil women from the grassroots with their vision and agenda for women (Azmi 2015). Similarly, in Latin America guerrilla movements the gender ideology played a positive role in mobilising women (Kampwirth's 2002).

Scholars have argued that the emphasis in Maoist ideology in Nepal on the emancipation of women and on ending gender discrimination attracted a large number of women to the cause (Tamang 2009; Manchanda 2004; Sharma and Prasai 2004). However, the literature does not provide clear-cut answers about women's own motivations and the roles of ideological commitment. Therefore, I became interested in examining women's private ambitions in the Maoist movement and how these connect with the emancipation agenda of the Maoist movement. Looking at the gender ideology helped me to understand how gender roles change. For example, I examined how women experienced crossing the traditional gender boundaries, becoming combatants, participating in the Maoist propaganda, taking roles equal to men, conducting protest, and performing leadership positions. When women were engaged in all these processes of Maoist activism, change in gender roles was supported.

By investigating gender ideology, I hoped to understand how women's own engagement in the ideology might produce a sense of empowerment and how this connected with the process of change in gender roles. I wanted to look at women's ideological motivation to comprehend how the ideological discourse shaped women's understanding of gender equality at the level of discourse and in their own lives. This would inform me about women's own motivation to question and challenge gender norms.

I was interested in studying how women relate to the particular ideological positions of the Maoist movement and how they connect this to what they describe as women's empowerment. Women described the sense of empowerment they experienced in their own words as: 'mahila sasahktikaran' (women's empowerment), 'where they could raise their voices' (awash uthaunne), 'women's voices were represented' (mahilako awaj ko pratinidithyo) and 'understanding women's grief'. 
Utilising the sexual division of labour and power structure framework helped me to understand women as motivated actors, in the sense that women are active participants in bringing changes to gender roles which is reflected through their involvement in the militarised Maoist war. Women are motivated to change their roles and are committed to achieving this goal.

\subsubsection{Structural Factors}

To understand whether the changes in gender roles during the process of war and disaster are temporary or permanent, I looked at structural factors which sustain or challenge such changes.

The scholarship to date has suggested that, although conflict and disaster might offer women a window for change, these changes might not last for long, and may roll back as 'normality' returns (El-Bhusra 2003; Enloe 2004; Rajasingham-Senanayake 2004; Azmi 2015). The literature to date suggests that structural factors play a role in this (Shekhawat 2015). Whereas individual women may experience considerable change in their roles, and the notion of appropriate roles for women is enlarged, this does not imply that gender roles change in a structural way. Structural factors including patriarchal norms that work against women and gender order (such as inequalities of income, class differences, division of roles in the family relationships) remain relatively intact despite the war or disaster, as well as discriminatory legal systems (Shekhawat 2015; Tamang 2009). In addition, challenges women encounter after returning from the war include stigmatisation. For instance, they are accused of losing womanhood, are considered to be spoilers and killers or are suspected of having been sexually abused (Azmi 2015; Bhandari 2015; Dahal 2015). Another reason why women face backlash and their voices are left-out in 'normal' times is because they are intentionally, or unintentionally, kept away from the decision-making process of post-war and post-disaster reconstruction programming (Cupples 2007; Shekhawat 2015). Enloe (2004, p.226) has observed in post-conflict settings: '...masculinised exclusion is made all the more intense... as a result, women's well-being in the reconstructed post conflict society will still be left on the proverbial back burner.'

The patriarchal system is persuasive in Nepalese society (Gurung 2018) and has operated at all levels of the social structure (Dhungana 2014). Therefore, to understand structural change, I investigated the factors in Nepalese society which act against gender role change. I was interested to see how these operate in practice and how they impact women's everyday lives. 
What I expected to find, on the basis of the literature cited above, was a potential tension between women's experiences of role change and the expectations society would have of them. As 'normality' starts to be resumed in the aftermath of crisis, society starts to refer to the importance of 'old norms' whereas women have experienced a 'new normality'. These two thoughts do not coincide.

I had a general idea of the kinds of challenges women might experience deriving from traditional gender norms and institutional limitations to gender equality in Nepal, such as unequal citizenship rights that force Nepali women to depend on men to achieve their rights and the discriminatory inheritance laws that make women's status weaker. However, my analysis would be led by what the women I studied considered the main obstacles and challenges they encountered in their daily lives. This brought out issues like stigmatisation based not only on gender but also on caste, the marriage system, the traditional preference for sons, and the acceptance or non-acceptance women experienced from their parents and in-laws. Women from lower caste, upper caste, and ethnic minorities experienced structural factors differently in their everyday lives.

Understanding these factors would help me to comprehend how such patriarchal structural factors work against gender role change and discriminated against women. I was interested also in how women addressed the challenges they encountered. This would help me understand how even where structural change is difficult, women may possibly find room for manoeuvre in their every day circles to exercise non-traditional gender roles and cross gender boundaries.

\subsubsection{The Role of Policy in Gender Role Change}

After the peace process was signed in 2006, Nepal implemented gender mainstreaming in policy to achieve gender equality. Therefore, I became interested in understanding how policy impacts gender role change in women's everyday lives.

A significant body of comparative literature on gender policy has shown that even where gender roles become more fluid during war times, and male and female combatants fulfil similar roles, post-war policies tends to be gender-exclusive and overlook the fact that female combatants encountered special challenges (Enloe 2004; Denov and Ricard-Guay 2013; Mazurana 2013). For example, in Uganda, and Sierra Leone due to 'one gun one combatant' 
disarmament policy, large numbers of women fighters were excluded from entering the Disarmament Demobilization and Reintegration (DDR) programme because women are more likely to be without a weapon (Mackenzie 2009; McKay and Mazurana 2004). In response, scholarly work on DDR drew attention to the need for integrating gender mainstreaming in order to address women's needs in the post-war period (Corrin 2010; Mazurana and Cole 2013). However, there are some known cases where gender mainstreaming policy reforms triggered women's empowerment in post-war settings such as in Mozambique, El-Salvador and Iraq where a gender quota system helped to increase women's political participation (Jacobson 2013, p.232). Similarly, in Rwanda, women acquired the right to own land as an outcome of structural policy transformation (ibid, p.233).

Although gender mainstreaming might bring women empowerment in the general context, scholars suggest that women's specific needs are not fulfilled by mainstreaming in policy and therefore there is a need to focus upon the root causes of women's vulnerability and respond to the factors that create inequality in women's lives (Horton 2012; Bhadshaw 2013; 2014). The question is whether the gender mainstreaming policy in Nepal translates into real change for women. Therefore, to understand this situation, I took the following approach. First, I investigated whether the Nepalese DDR policy had integrated a gender-inclusive framework at the level of discourse. Secondly, I examined how women experienced DDR policy and programmes in their everyday lives, and what it meant to them. Thirdly, I looked at Communist Party of Nepal (Maoist) commitment to gender equality policy and women ex-combatant's own ideological drive in the post-conflict period. Fourthly, I examined how the post-war policy served women non-combatants' needs. Finally, I looked at whether there are parallels between how post-conflict policies dealt with women's issues and how post-disaster policies dealt with them.

Understanding the role of post-conflict and post-disaster policy helped me to find out how women encountered range of challenges due to the absence of 'gender inclusiveness' in the policy. Through investing in this process, I became aware that, due to the negligence of the CPN (Maoist party) regarding women's agenda, they struggled generally. At the same time, I realised, some women non-combatants benefited from the training programme and loan schemes which they received from NGOs aftermath of the war. Furthermore, I also understood that by gender mainstreaming in policy such as gender quota systems, are highly politicised, and available mostly to elite/privileged women's groups. Similarly, I found that women 
earthquake survivors were unable to reach a range of post-disaster relief programmes because of the discriminatory legal system.

The impact of policy on gender-role change provides mixed evidence, in case of women noncombatants it offered them economic prosperity, whereas, women ex-combatants and women earthquake survivors were not benefited from this process. Gender roles may, or may not, have been transformed, changed, altered, or retained, but women haven't lost their hope of achieving gender role change. They are fighting back through bringing their issues to the streets and creating pressure for gender inclusive policies in Nepal.

\subsection{Thesis Outline}

Below, I briefly outline the four substantive chapters of this thesis.

Chapter 3: Changing Gender Role: Women's Livelihoods, Conflict and Post-Conflict Security in Nepal

This chapter investigates experiences of both women ex-combatants and non-combatants on shifts in gender roles during the Maoist conflict and what challenges women face to sustain their shift in roles in the post-conflict settings in Nepal.

Chapter 4: Living Maoist Gender Ideology: Experiences of Women Ex-Combatants in Nepal

This chapter traces women's ideological motivation and experiences during and after the Maoist insurgency in Nepal. The paper demonstrates how women's ideological commitment to Maoist gender ideology offers an avenue of empowerment and a shift in their gender roles, and what happened to women's ideological drive, and empowerment in the post-conflict period.

Chapter 5: Everyday Realities of Reintegration: Experiences of Maoist 'Verified' Women ExCombatants in the Aftermath of War in Nepal

This chapter examines the consequences of the DDR process for so-called 'verified' female ex-combatants. 'Verified' means those who were formally acknowledged as former 
combatants. These women experienced the entire DDR process. The paper examines how DDR policy shapes women's everyday lives, and how this process impacts women's post-conflict options, with a focus on reintegration. The paper first problematises the very idea of a 'return to normality' and, second, shows how female ex-combatants suffered multiple forms of marginalisation as they sought to give new shape to their lives in the post-conflict era in Nepal.

Chapter 6: Exploring Gendered Effects of the 2015 Earthquake in Nepal Through Women's Eyes

This chapter investigates the challenges women earthquake survivors faced in the wake of the post-earthquake period, how these were related to their gender position and how gender roles changed in the time of the earthquake in Nepal. 


\subsection{References}

Adhikari, A. (2012). Revolution by Other Means: The Transformation of Nepal's Maoists in a Time of Peace. In Einsiedel, V. S., Malone, D. M., \& Pradhan, S. (Eds). Nepal in Transition: from People's war to Fragile Peace (pp. 265-283). Cambridge University Press.

Afshar, H., \& Eade, D. (2004). Development, Women and War: Feminist Perspectives. Oxfam Publications.

Alison, M. H. (2009). Women and political violence: female combatants in ethno-national conflict (First). London: Routledge.

Arostegui, J. (2013). Gender, Conflict, and Peace-Building: how Conflict can Catalyse Positive Change for Women. Gender \& Development, 533-549. https://doi.org/10.1080/13552074.2013.846624

Azmi, F. (2015). IWantMyWings Back to Fly in a New Sky: Stories of Female Ex-LTTE Combatants in Post-War Sri Lanka. In S. Shekhawat (Eds.). Female Combatants in Conflict and Peace: Challenging Gender in Violence and Post-Conflict Reintegration (pp. 200-215). London: Palgrave Macmillan.

Basnet, B. (2005). Trapped In Conflict: Although the Maoist Insurgency Has Claimed the Lives of Men in Huge Numbers, It Has Affected Women and Children No Less. Spolights Weekly, 24 (25), 14-20.

Bradshaw, S. (2001). Reconstructing Roles and Relations: Women's Participation in Reconstruction in Post-Mitch Nicaragua. Gender \& Development, 9(3), 79-87. https://doi.org/10.1080/00223891.2011.608754

Bradshaw, S. (2013). Gender, Development and Disasters. UK: Edward Elgar.

Bradshaw, S. (2014). Engendering Development and Disasters. Disasters, 39, 54-75.

Butler, J. (1990). Gender Trouble and the Subversion of Identity. New York and London: Routledge.

Buvinic, M., Dasgupta M., Casabonne, U., Verwimp, P. (2012). Violent Conflict and Gender Inequality: An Overview. The World Bank Research Observer, 28 (1), 110-138. doi: 10.1093/wbro/lks011

Chetwynd, J., \& Hartnett, O. (1997). The Sex Role System: Psychological and Sociological Perspectives. London: Routledge .

Cohn, C. (2013). Women \& Wars. Cambridge: Polity Press.

Constitution of Nepal. 2015. The Government of Nepal. Kathmandu: Ministry of Law, 
Justice and Parliament Affairs.

Cupples, J. (2007). Gender and Hurricane Mitch: Reconstructing subjectivities after disaster. Disasters, 31(2), 155-175. https://doi.org/10.1111/j.1467-

7717.2007.01002.x

Dahal, S. (2015). Challenging The Boundaries The Narratives of the Female Ex-combatants. In S. Shekhawat (Eds.), Female Combatants in Conflict and Peace: Challenging Gender in Violence and Post-Conflict Reintegration (pp. 185-199). London: Palgrave Macmillan.

Dhungana, R. K. (2014). Nepali Hindu Women's Thorny Path to Liberation, School of Education, Kathmandu University, Lalitpur, Nepal. Journal of Education and Research, 4(1), 39-57.

Denov, M., \& Gervais, C. (2007). Negotiating (In) security: agency, resistance, and resourcefulness among girls formerly associated with Sierra Leone's Revolutionary United Front. Signs. Journal of Women in Culture and Society, 32(4), 885-911. doi: $10.1086 / 512488$

Denov, M., \& Ricard-Guay, A. (2013). Girl soldiers: towards a gendered understanding of wartime recruitment, participation, and demobilisation. Gender \& Development, 21(3), 473-488.

Gautam, S., Banskota, A., \& Manchanda, R. (2001). Where There Are No Men Women In The Maoist Insurgency in Nepal. In D. Thapa (Eds.), Understanding the Maoist Movement in Nepal (pp. 93-124). Kathmandu: Martin Chautari.

Enarson, E., \& Morrow, B. H. (1998). Why Gender? Why Women? An Introduction to Women and Disaser. In E. Enarson \& B. H. Morrow (Eds.), The Gendered Terrain of Disaster (pp. 1-9). London: Praeger.

El-Bushra, J. (2000) 'Transforming conflict: some thoughts on a gendered understanding of conflict dynamics', in S. Jacobs, R. Jacobson, and J. Marchbank (eds.) States of Conflict: Gender, Violence and Resistance, London: Zed Books.

El-Bushra, J. (2003). Fused in combat: Gender relations and armed conflict, Development in Practice, (13)2-3, 252-265, doi:10.1080/096145203200007

Enloe, C. (2004). The Curious Feminist Searching for Women in a New Age of Empire.

Grabska, K. (2013). The return of displaced nuer in southern sudan: women becoming men? Development and Change, 44 (5), 1135-1157. doi: 10.1111/dech.12051.

Fothergrill, A. (1998). The Neglect of Gender in Disaster Work: A Overview of the Literature. In E. Enarson \& B. H. Morrow (Eds.), The Gendered Terrain of Disaster: 
through women's eyes (pp. 11-25). London: Praeger.

Fuest, V. (2008). 'This is the Time to get in Front': Changing Roles and Opportunities for Women in Liberia. African Affairs, 107(427), 201-224.

Greene, S. (2015). Gender and Sexuality in Nepal: The Experiences of Sexual and Gender Minorities in a Rapidly Changing Social Climate.

Gurung, D.2018. Perpetuating Patriarchy in Nepal. Retrieve from https://www.nepalitimes.com/opinion/perpetuating-patriarchy-in-nepal/

Goswami, R. (2015). UNSCR 1325 and Female Ex-Combatants-Case Study of the Moiast Women of Nepal. New York.

Hamal, B. (2007). Impacts of Armed Conflicts on Women in Nepal. Gender, Technology and Development, 11(2), 235-242. https://doi.org/10.1177/097185240701100205.

Hilhorst, D. (2001). The Power of Discourse: NGOs, Gender and National Democratic Politics. Asian Studies, 37(1), 1-35.

Hilhorst, D., Porter, H., \& Gordon, R. (2018). Gender, Sexuality, and Violence in Humanitarian Crises. Disasters, 42, S3-S16. https://doi.org/10.1111/disa.12276.

Hutt, M. (2004). Himalayan Peole's War Nepal's Maoist Rebellion. Bloomington, Indiana: Indiana University Press.

Knight, M., \& Özerdem, A. (2004). Guns, Camps and Cash: Disarmament, Demobilization and Reinsertion of Former Combatants in Transitions from War to Peace. Journal of Peace Research.https://doi.org/10.1177/0022343304044479

Humphreys, M., \& Weinstein, J. M. (2005). Disentangling the Determinants of Successful Demobilization and Reintegration. Annual Meeting of the American. https://doi.org/http://dx.doi.org/10.2139/ssrn.984246

Horton, L. (2012). After the earthquake: Gender Inequality and Transformation in PostDisaster Haiti. Gender \& Development, 20(2), 295-308. https://doi.org/10.1080/13552074.2012.693284

Irshad, H., Mumtaz, Z., \& Levay, A. (2012). Long-term Gendered Consequences of Permanent Disabilities Caused by the 2005 Pakistan Earthquake. Disasters, 36(3), 452464. https://doi.org/10.1111/j.1467-7717.2011.01265.x

Jacobson, R. (1999). Complicating "Complexity": Integrating Gender into the Analysis of the Mozambican Conflict. Third World Quarterly, 20 (1), 175-187.

Jacobson, R. (2013). Women 'after' wars. In Carol Cohn (Eds.), Women and wars (pp. 215242). Cambridge: Polity Press.

Jacobs, S., Ruth, J., \& Marchbank, J. (2000). States of Conflict: Gender, Violence and 
Resistance. (S. Jacobs, J. Ruth, \& J. Marchbank, Eds.). New York: Zen Books.

Kattel, M. (2003). Introduction to' The People's War and Its Implications. The People's War in Nepal: left Perspectives, 49-72.

K.C., Luna. (2011). Securing Livelihood: Reintegration of Mother Ex-Combatants in Post

Conflict Nepal. M.Sc.,Wageningen University, the Netherlands.

Kimmel, M. 2000. The Gendered Society, Oxford: Oxford University Press.

Kampwirth, K. (2002). Women and Guerilla Movements: Nicaragua, El Salvador, Chiapas, Cuba (First). University Park, Penn: Penn State University.

Karki, A., \& Seddon, D. (2003). The People's War in Nepal Left Perspectives. Adroit Publishers.

Limbu, S. T. (2018). Researching Women's Political Inclusion in the 2017 Local elections: Some comments and findings. Retrieved September 7, 2018, from www.undp.org/content/nepal

Lawoti, M., \& Pahari, A. K. (2009). The Maoist Insurgency in Nepal Revolution in the Twenty-First Century. Routledge.

Manchanda, R. (2004). Maoist Insurgency in Nepal: Radicalizing Gendered Narratives. Cultural Dynamics, 16, 237-258.

https://doi.org/10.1177/0921374004047750

Mazurana, D., \& Cole, L. E. (2013). Women, Girls and Disarmament, Dembolization and Reintegration. In C. Cohn (Eds.), Women and Wars (pp. 194-214). Cambridge.

Moosa, Z., Rahmani, M., \& Webster, L. (2013). From the private to the public sphere: new research on women's participation in peace-building. Gender \& Development, 21(3), 453-472.

Mckay, S., \& Mazurana, D. (2004). Where are the Girls? Girls in Fighting Forces in Northern Uganda, Sierra Leone, and Mozambique. Their lives Before and After War. Gender Studies Database.

N. Cahn and F. Ní Aoláin (2009) 'Hirsch Lecture: Gender, Masculinities and Transition in Conflicted Societies', New England Law Review, Vol. 44, 2-9.

Mlinarević, G., Isaković, N. P., \& Rees, M. (2015). If women are Left out of Peace talks. Forced Migration Review, 50, 34-37.

Nepal Institute for Policy Studies. (2013). Nepal's Peace Process : A Brief Overview Nepal Institute for Policy Studies ( NIPS ). Policy Paper (Vol. 8).

Nepal Monitor. (2011). Recording Nepal Conflict: Victims of Numbers. Retrieved October 6, 2018, from 
http://www.nepalmonitor.com/2011/07/recording_nepal_conf.html

Parvati, C. (2003). Women's Participation in the People's War. In A. Karki \& D. Seddon (Eds.), The People's War in Nepal Left Perspectives (p. 495). Adroit Publishers.

Perera-mubarak, K. N. (2013). Positive Responses, Uneven Experiences : Intersections of Gender, Ethnicity, and Location in Post-Tsunami Sri Lanka. Gender, Place \& Culture, 20(5), 664-685. https://doi.org/10.1080/0966369X.2012.709828

Pettigrew, J., \& Shneiderman, S. (2004). Women and the Maobadi: Ideology and Agency in Nepal's Maoist Movement. Himal Southasian, 17(January), 19-29.

Poudel, P., \& Carryer, J. (2000). Girl-trafficking, HIV/AIDS, and the Position of Women in Nepal. Gender \& Development, 8(2), 74-79.

Pyakurel, U. (2008). The Vision of the Jana Andolan II for a future of nepal. In Sustainable Cultures - Cultures of Sustainability (pp. 1-17).

Rajasingham-Senanayake, D. (2004). Between Reality and Representation: Women's Agency in War and Post-Conflict Sri Lanka. Cultural Dynamics, 16(2-3), 141-168. https://doi.org/10.1177/0921374004047741

Radtke, H. L., \& Stam, H. J. (1994). Power/gender: Social Relations in Theory and Practice. London: Sage Publication

Ramnarain, S. (2014). Universalized Categories, Dissonant Realities: Gendering Postconflict Reconstruction in Nepal. Gender, Place \& Culture, 22(9), 1305-1322.

Ruwanpura, K. N., \& Humphries, J. (2004). Mundane Heroines: Conflict, Ethnicity, Gender, and Female Headship in Eastern Sri Lanka. Feminist Economics, 10(2), 173-205. https://doi.org/10.1080/0966369X.2014.958062.

Sanı'n, G.F. \& Wood J.E. (2014). Ideology in Civil War: Instrumental Adoption and Beyond, Journal of Peace Research, 51 (2): 213-226.

Sjoberg, L., \& Peet, J. (2011). A(nother) Dark Side of the Protection Racket. International Feminist Journal of Politics, 13(2), 163-182. https://doi.org/10.1080/14616742.2011.560751

Tamang, S. (2009). The Politics of Conflict and Difference or the Difference of Conflict in politics: the Women's Movement in Nepal. Feminist Review. (91), 61-80. Retrieved 3 March 2017, goo.gl/iXeiKS

Thapa, D. (2003). Understanding the Maoist Movement of Nepal. Kathmandu: Modern Printing Press.

Thapa, G., \& Sharma, J. (2009). From Insurgency to Democracy: The Challenges of Peace and Democracy-Building in Nepal. International Political Science Review, 30(2), 205- 
219. https://doi.org/10.1177/0192512109102437

Upreti, B., \& Muller-Boker, U. (2010). Livelihood Insecurity and Social Conflict in Nepal. South Asia Regional Coordination Office, Swiss National Centre of Competence in Research (NCCR) North-south, Kathmandu.

Upreti, B. R., \& Kolås, Å. (2016). Women in Nepal's Transition. PRIO Policy Brief, (11), 2016.

Yadav, P. (2016). Social Transformation in Post-conflict Nepal. Taylor and Francis:ProQuest Ebook Central.

Yadav, P. (2016). White Sari Transforming Widowhood in Nepal. Gender, Technology and Development. 20(1): 1-24. doi: 10.1177/0971852415618748.

Ugarriza E.J.\&CraigJ.M. (2012). The Relevance of Ideology to Contemporary Armed Conflicts: A Quantitative Analysis of Former Combatants in Colombia. Journal of Conflict Resolution.57 (3):445-477.

UN OHCHR. (2012). Nepal Conflict Report 2012. Geneva. Retrieved from http://www.ohchr.org/Documents/Countries/NP/OHCHR_ExecSumm_Nepal_Conflict _report2012.pdf

Einsiedel, V. S., Malone, D. M., \& Pradhan, S. (2012). Nepal in Transition: from People's war to Fragile Peace. Cambridge University Press. 
Chapter 2: Methodology 


\subsection{Study Area}

In this chapter, I present the methodology applied to conduct this study. This research is based on multiple sites. To study women ex-combatants and non-combatants, the field-work was carried out in Jutpani and Padampur of Chitwan district, and Kapan area of Kathmandu district of Nepal, from January 2014 to February 2015. To examine women earthquake survivors the research was conducted in Bungmati village of Lalitpur district, from May to September 2015.

The Chitwan district lies in province ${ }^{2}$ No. three and is one of the seventy-seven districts of Nepal. It is located in the mid-western region (Fig. 1). The district, with Bharatpur as its district headquarters, covers $2,218 \mathrm{~km}^{2}$ and has a population of 579,984 (CBS, 2012). Until the 1950s, the Chitwan lowlands were sparsely populated by indigenous, malaria-resistant people, mostly Tharus and some Bhote and Bharai. Now the district comprises people of diverse caste and ethnicity such as Gurung, Brahman, Chepang, Tamang, Tharu, Madhesi, Dalit, Newar (UN, 2008). This District was severely hit by the Maoist conflict which threatened the livelihoods of people and included killings, military incursions, abductions, army searches, and attacks by Maoist and military forces (International Crisis Group, 2003). This research was conducted in two villages of Chitwan district, Padampur and Jutpani. During the Maoist conflict one of the Maoist cantonment ${ }^{3}$ sites was built near Jutpani called 'Shakti-khor'. Some women excombatants lived in this cantonment, and a few came from other areas after their demobilisation in 2012. Similarly, some non-combatant women interviewed for this study fled Chitwan from other districts in fear of the war, and in search of protection, security, and work.

The Kathmandu district lies in province number three, one of the three districts of Kathmandu valley. It is located in the central region of Nepal (Fig.1). The district, with Kathmandu as its headquarters and capital of the country, covers $395 \mathrm{~km} 2$ and has a population of 1,744,240 (CBS, 2012). Although Newar ${ }^{4}$ are the indigenous inhabitants of the Kathmandu valley, the 2011 census shows that the Kathmandu district now consists of a $44 \%$ migrant population. This demographic shift has turned the city into a cosmopolitan urban population

\footnotetext{
${ }^{2}$ All of my study areas are in Province No. 3. In 2017, during the process of state restructuring, the country was divided into seven Provinces replacing an earlier system of 14 administrative zones.

${ }^{3}$ Cantonment: is temporary camps where Maoist combatants were settled as a part of the peace process in Nepal. There were 7 major and 21 satellite cantonments.

${ }^{4}$ An ethnic group of Nepal, having their own language Newari.
} 
whose residents are of multiple and diverse castes, ethnicities and cultures (UNESCO, 2015). Kathmandu is now a political, commercial and cultural hub with a growing population due to the Maoist conflict and subsequent unrest in lowland Nepal (Muzzini and Aparicio, 2013; Suwal 2014). Chapter 2 of this thesis offers the stories of women non-combatants living in Kapan area of Kathmandu. During the Maoist war, these women escaped here in search of work and protection, and then stayed after the war ended. Kapan is a suburban area situated in the northern part of the Kathmandu district. This was popular destination for new settlement due to the opportunities.

The Lalitpur district is situated in the Kathmandu valley and located in province number three. This district occupied an area of $385 \mathrm{~km} 2$ and comprised a population of 466,784 (CBS, 2012). In Lalitpur district, Newars are the indigenous inhabitants of this area. After Kathmandu, Lalitpur is the second largest district with migrant population (33\% of the total population) (Suwal, 2014). As stated above, this migration resulted from the people fleeing the Maoist conflict and political instability for security and economic opportunities. Chapter six of this thesis mainly focused on women earthquake survivors located in the Bungmati area, a small and ancient Newari village situated in southern part of Lalitpur. This classic medieval village was one of the hardest hit areas by the 2015 earthquake, where more than $75 \%$ of the residential structures were either severely damaged or made inhabitable. About six people were killed and more than 50 people were injured (HRRP-Nepal 2017). 


\subsection{Map of the Study Area}

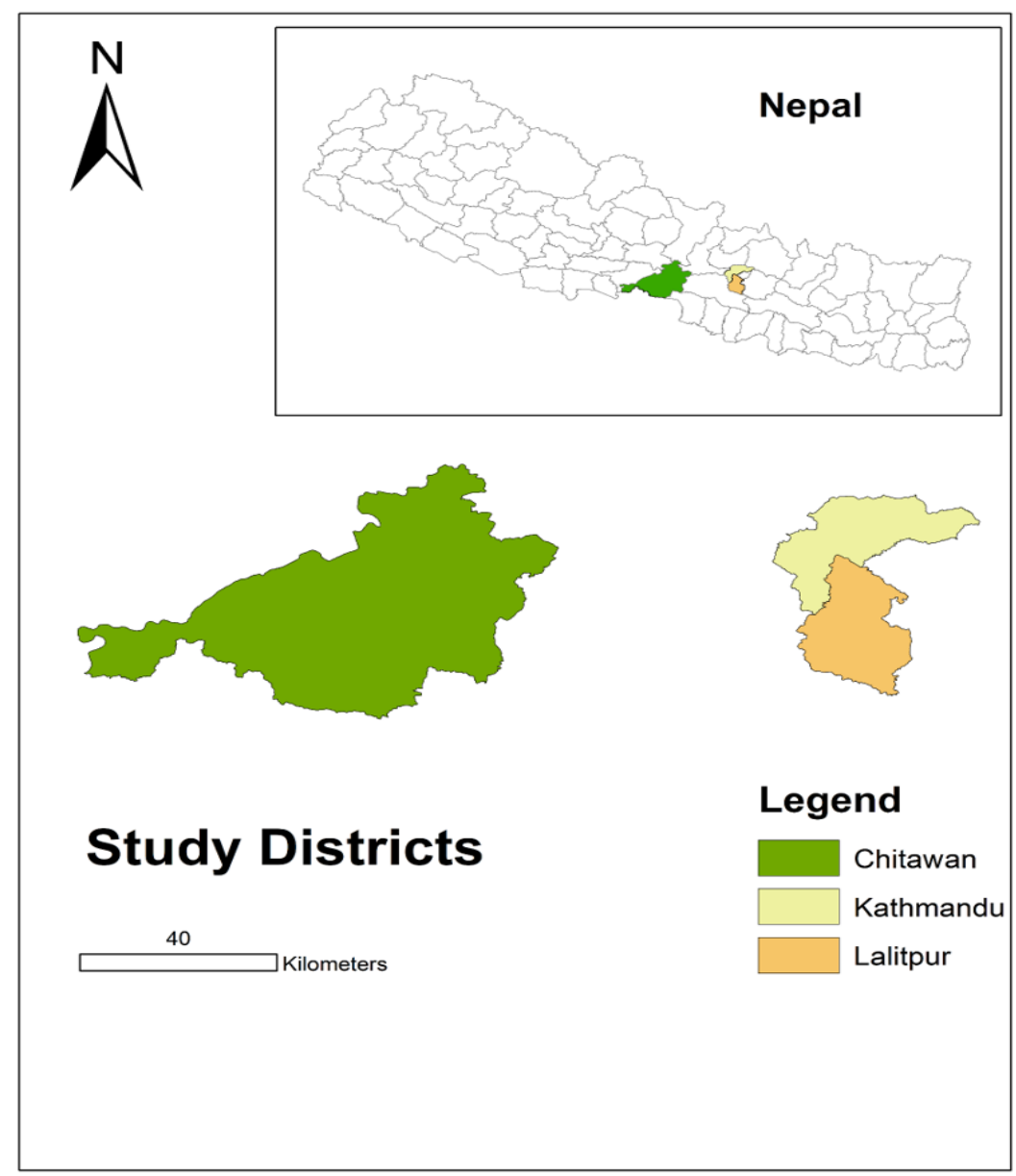

\subsection{Methodological Choices}

This chapter presents the researcher's experiences of conducting field-work for this thesis. It details the process of finding the respondents, negotiating access in the field, conducting interviews, and reflecting on the researcher's positionality.

The study applied an ethnographic approach by utilising in-depth interviews, focus-group discussions, participant observation, and key informant interviews (Greeen and Thorogood, 2009). The ethnographic method was chosen due to the nature of this project which explored women's everyday experiences in the conflict and disaster. This study is also informed by feminist methodology which argues that research should not just done on women, but for women and, where possible, with women (Fonow and Cook, 1991; Ramazanoglu and Holland, 2002). This method asks to study women's lives deeply, undertaking interviews in an open, 
unstructured, reciprocal, and non-hierarchical way (ibid). As this thesis is grounded upon women's everyday lives, utilizing feminist methodology allowed me to arrange open and reciprocal interviews, where women were able to share their stories in the ways they felt comfortable. Maintaining non-hierarchical relationships helped to understand women's lives more closely and in-depth, and to ground-up their voices.

This research was conducted in a conflict-affected setting and faced various methodological challenges. The study is encouraged by Van der Haar, Heijmans, and Hilhorst's (2013, p32) work which suggests 'conflict research needs to understand and analyse local actors' choices and considerations and the interaction between local actors and researchers'. This approach opens an avenue for researchers who are interested in working in conflict-affected/post-conflict zones and provides a methodology to develop research in cases where conditions require the researcher to work with scattered knowledge (ibid).

I became interested in working with women on Maoist conflict and post-conflict issues while engaged on my master's thesis on "securing livelihoods: reintegration of former Maoist mother combatants with children in post-conflict Nepal. I found there are not many studies in Nepal on how women experience gender role transformation during the Maoist conflict, and the effects of such role transformation upon women in the post-war settings. Therefore, building upon my master's thesis I embarked on this doctoral study which aims to answer how gender roles transform during conflict/disaster and the sustainability of such changes beyond these crises.

This thesis is primarily about Maoist women ex-combatants and non-combatants' experiences in gender role change during and after the Maoist conflict. Later, upon completion of the data collection, in April 2015, I was preparing to return to Wageningen University (my host university) to start the writing. On 25th April 2015, a 7.8 magnitude earthquake hit Nepal. During this time, I was still in Nepal and the earthquake had a bad impact on me and my family: We faced physical injuries, were displaced for 3 months until our home was safe and lived in a tent in the interim. We suffered from trauma (long-lasting fear of the shakes and sleepless nights). During that time, while living my everyday life and seeing and knowing women who also lived through the disaster and crisis in their own ways, I became interested in following the disaster. In line with the central interest in my thesis, in how women organise their lives in crisis-affected situations, I extended my data gathering in order to ask how women live and 
survive during earthquake situation, and afterwards. Doing this 'real-time ethnography' added a new dimension to my thesis.

\subsection{Finding Respondents ${ }^{5}$ and Negotiating Access}

This section explains my experiences in finding respondents. I will explain how I faced more challenges while finding the Maoist women ex-combatants and less for non-combatant women, and women earthquake survivors. I will also present how site selection depended upon the respondents' mobility and their interest in participating in the research.

In December 2013, I went to Nepal to begin my field-work. I started by contacting my previous network, notably the Ministry of Peace and Reconstruction (MoPR) personnel to see if they could link me to women ex-combatants. The MoPR informed me that they did not have contact addresses of ex-combatant women, only their names, the reintegration packages they opted for, and the date they demobilised. I then called a Maoist leader whom I had been in contact with while doing my master's thesis, and I asked him if he could connect me with any women excombatants and later, I visited the leader in Kathmandu. He also stressed the difficulty of tracing female ex-combatants. During the first meeting he said, 'Now after their [Maoist excombatants] demobilisation it will be very hard to identify their new location because all of them moved to various locations... all over the country, and I do not have their information...I heard some of them even moved from a first location to a next location'

As I insisted, this Maoist leader then connected me with five other Maoist leaders. Later, at a meeting, I shared my research proposal and study objective, and this influenced his willingness to help. During the meeting, one of the leaders referred me to another local leader in Chitwan district. I went to Chitwan to meet him and afterwards he gave me the contact details of six women ex-combatants. Not all of them accepted my interview proposal; some said they had already been interviewed by other researchers; and others said they were not interested in sharing their stories.

\footnotetext{
${ }^{5}$ Here and elsewhere in the thesis I am referring to people with pseudonyms.
} 
The first woman ex-combatant who was willing to talk to me on the telephone was Sapana. At the beginning of our conversation, I explained my Ph.D. research topic and the purpose of the study. I shared with her my previous field experience visiting cantonments in 2010-2011 while doing my master's thesis and meetings with her fellow Maoist ex-combatants. I also introduced myself by providing my family background. This convinced her to collaborate with me. At the same time, she also asked me many questions: why are you interested in our story, why are you doing this study, and what will the discussion be like, and what will happen after doing this type of research? I answered all her queries rationally and clearly. After having a few more telephone conversations, she agreed to meet me. I went to her home, we went to have a tea together, and while having tea, she again asked me many questions. Are you married? Do you have children? Which caste are you from? Where do you live in Kathmandu? How did you end up doing research in a foreign university? What type of job will you get after doing such studies?

Later, when I returned to Chitwan a second time, Sapana introduced me to three other women ex-combatants (Gita, Binita and Usha) They also asked many questions like Sapana, and I answered all their questions honestly. This persuaded the women ex-combatants to support my study which, in turn, made me to decide to carry out the Ph.D. field work in Chitwan district. Another reason for choosing Chitwan is because when I contacted five other women excombatants living in Rupandehi and Nawal-parasi districts all of them refused to be interviewed.

While accessing women ex-combatants, I learn that selection of the site in advance did not work where women-combatants were involved. The Maoist women ex-combatants in Nepal, after the ending of the official disarmament, demobilisation and reintegration programmes, returned to various new locations due to lack of opportunities in their previous home-town (original place of belonging before joining the Maoist war), to detach themselves from war memories, or to build a new life and to stay together with their war peers.

Finding women non-combatants was less challenging because they were already living in the local community both during the conflict and after. I started approaching non-combatant women when I started the fieldwork in Chitwan. I began to build networks with the local people and local organisations by going to the local market, attending marriage ceremonies, visiting pharmacies, doing shopping, visiting tailors' shops, tea shops, and restaurants etc. Whenever I 
visited these places, I chatted with people and asked if they knew women-headed households affected by the Maoist war. The local people cooperated with me and connected me with women non-combatants. The next group of women non-combatants I got in contact with was from SLISHA, an NGO working in Kathmandu district. I attended SLISHA meetings few times and met women who were affiliated with this NGO.

The connection with women earthquake survivors was easier to establish. I interacted mostly with women from Bugamati village (which lies in Lalitpur district of Nepal) because I knew some of these women before the earthquake and was introduced to more women immediately after the earthquake. While surviving the earthquake, I worked with them closely, sometimes the whole afternoon. I helped them to discover relief distribution information, joined them in debris clearance. We shared our crisis stories over tea and became friends.

\subsection{The Women's Profiles}

In this section I aim to provide more information about the women I interviewed. In the case of the ex-combatant women, however, I cannot make the description too specific as they might be too easily traced. Though the topic of the Maoist war was sensitive when I began my research, it has become even more so in recent years as the Maoist political situation has changed. The Maoist party split into three political parties, and in the 2017 election (both central and local level), the Maoists faced a big fall in popularity, losing the majority of the seats. In 2008, they were the largest in Nepal, leading the government during this period. This political change has produced further complexity in the situation of Maoist women excombatants as well.

The thirty-five women ex-combatants I interviewed were between 25-35 years, and all of them were married to Maoist combatant men and had one or two young children. These all women were so-called Maoist 'verified' women ex-combatants, 'verified' meaning those who were formally acknowledged as former combatants. They experienced the entire DDR process in the post-war context. All of these women were originally from other districts of Nepal. Among them, four were married before the war, some got married during the war and others while living in the cantonment (at the ending of the war). They belong to diverse castes and ethnic 
groups ${ }^{6}:$ Tamang (Hill ethnic group), Magar (Hill ethnic group), Thami (ethnic minority), Gurung, Rai, Limbu, Tharu, Dalit; two women were from high castes (Bahun and Chettri). The majority of the women had only primary education (class 1-5), and only few had completed secondary school.

The twenty women non-combatants I interviewed experienced severe impacts of the Maoist conflict (either widows, or households head) with ages ranging from 25-40. All of them were married with children. These women had migrated to Kathmandu and Chitwan during the time of war seeking protection and livelihood options for their family; their husbands were either killed or became Maoist or were displaced during the war. Most of them had only primary education, among them three completed high school.

The twenty-two women who had suffered from the earthquake ranged in age from 20-30. They were also all married with children. The majority of them had not been to school but three had been to the primary school. The nine migrant women came from other districts such as Kavre, Dolakha and Sindupalchowk, and others are local women of the Bugamati region.

\subsection{In-depth Interviewing}

This research relied on in-depth interviewing (Legard, Keegan, and Ward 2003, p.144) as a key methodology. I conducted in-depth interviews with thirty-five women ex-combatants, twenty women non-combatants, and twenty-two women earthquake survivors. Employing this method provided the necessary flexibility. We could discuss any theme, let the conversation flow naturally, switching to the next topic as we wanted and going deep into the conversation. At the beginning of the interview, we both (the respondent and I) thought about tentative topics for conversation but were not limited to this. Women were welcome to share whatever they felt important. For instance, while speaking on the broad topic of the woman's life before joining the Maoist movement, some women talked for about two hours. In the same way women noncombatants (widows) also talked for very long periods on their experiences of the Maoist war, and becoming a household head. Normally, interviews lasted from one and a half to two hours, depending upon the topic and women's time availability. Also, sometimes interviews were

\footnotetext{
${ }^{6}$ Caste and ethnic groups: Tamang, Magar, Thami, Gurung, Rai, and Limbu are hill ethnic groups in Nepal. Tharu is an indigenous group. Dalit is the untouchable caste, and Bahun and Chettri are upper-caste.
} 
unexpectedly interrupted and cancelled for a variety of reasons: women needed to go to the school to pick up a child who got suddenly sick, a guest appeared, and they went to prepare tea or lunch, they had to participate in suddenly announced cooperatives meetings or school meetings, or they had to accompany their in-laws to the hospital etc. In such cases I would make another appointment.

All the in-depth interviews were unstructured. I chose to do that to create a comfortable environment, to recognise the voices of the women. Unstructured interviewing also seemed more suitable to discuss personal experiences of performing new roles in the war/disaster and in its aftermath. In this way I also avoided the possibility that some questions might be offensive to women. This method of interviewing also helped to maintain a non-hierarchical relationship between the researcher and researched (Legard, Keegan, and Ward 2003).

Most of the women I interviewed did not have full-time office jobs nor even part-time, but this did not mean they were free, and I could start interviewing them anytime. Rather, women's everyday schedules were quite occupied with their household chores, taking care of their children, rearing livestock, fetching water, cooking meals or washing dishes, going to the market, attending local meetings etc. I made an appointment according to their availability and flexibility. During my stay in the field, I frequently visited their homes and joined in everyday activities: doing grocery shopping together, having tea, sometimes lunch, going to the hairdresser, walking together to their children's school, attending marriages, meetings. I also observed their everyday routine.

I came to realise that follow-up interviews were very helpful in generating additional information. Often in the second visit an interviewee developed more confidence and opened -up more compared to earlier conversations. For example, one of my respondents during the conversation on 'sources of livelihood' hesitated to share this information. A few months later, when I met her again, we had a cup of tea, and scheduled another interview. This time she herself shared her livelihood sources and I found her more openly talking to me than on previous occasions.

In the case of women who had just survived an earthquake stories were exchanged initially about what happened during the quake, and how they were rescued. The interviews were indepth in the form of storytelling: women were encouraged to talk about what happened and 
how they felt, how they experienced the earthquake and post-earthquake, their gender roles and responsibilities in the process, and their responses towards evacuation, relief, recovery and beyond.

\subsection{Focus Group Discussion}

I conducted a numbers of focus group discussion (FGD) for this study (Kitzinger 1994; Green and Thorogood). I used this method to obtain additional information that was not available during the interviews. In the focus group discussions, specific topics were covered such as experience of reintegration programmes, gender roles transformation, Maoist post-war politics, post-war Maoist leadership and gender equality. Discussing particular topics in a group provided different perspectives about the same topic and offered extra knowledge which was useful for this study.

I conducted six focus group discussion (FGD): four with women ex-combatants and two with women non-combatants. Each FGD consists of 5-6 people. I selected Maoist women excombatants who had participated in the entire disarmament demobilisation and reintegration (DDR) process. Likewise, while conducting FGD with non-combatant women I selected women severely affected by Maoist conflict (war widows/women head of the households).

I also conducted two FGD with 10 male ex-combatants, husbands of women ex-combatants. Further, I interviewed five non-combatants husbands of non-combatant women. Interviewing men allowed me to understand their views about women's gender role transformation and the sustainability of such changed roles in post-war settings.

\subsection{Participant Observation}

Participant observation allows the researcher to observe the activities of the people, the physical characteristics of the social situation, and what it feels like to be part of that scene (Hastrup and Hervik 1994; Zahle 2012). The method allowed me to understand the issues that remained uncovered by interview and which were useful for my study. For example, my thesis aims to reveal gender roles. During interviews, two women from different households stated in post-war setting I and my husband share equal work-load and gender roles are performed equally in my households'. However, in the field, I observed these two women did not receive 
help from their husbands while doing household tasks. Even if the men had free time, they relax with their friends but do not help their wives. At the same time, I also observed a few other men who supported their wives by taking care of the children or going to the market.

While living in Chitwan, I also attended a marriage ceremony of the brother of one of the participants and I observed in that household that both women and men were involved keeping the expenses, doing the shopping, finalising the guest list, catering, and welcoming the guests. Likewise, I visited a small restaurant in Kathmandu operated by a women non-combatant where I observed that this woman was heading her business: for example, dealing with the vendors, keeping the accounts, taking the orders, and talking with the customers. This method helped to triangulate the information that was provided in the interview process with the observed reality on the ground.

\subsection{Key Informant Interviews}

According to Tremblay (1957) the key informant interview technique is useful to obtain information of entire surroundings by interviewing few informants. I conducted key informant interviews with Maoist leaders in which they shared their views on the Disarmament Demobilization and Reintegration (DDR) process and the situation of women ex-combatants. This helped me to understand the recent context. In Chitwan, I also talked with local shopkeepers, school teachers, and local community leaders to understand their perceptions of the reintegration of Maoist ex-combatants and the women's position in society in the aftermath of the Maoist war and the changes in gender roles. This information was useful for my thesis.

\subsection{Positionality and Reflexivity}

In research settings, researchers choose to situate themselves within a given situation in relation to the subject, the participants, the research context and process (Savin-Baden and Howell Major 2013,71). Some features of positionality are culturally defined such as gender, race and nationality. Other aspects like personal life history and experiences are subjective and contextual (Merriam et al. 2001). I am aware that these arguments also apply to myself: my personal history, identity, the knowledge and relationship of the context. My study is about women's lived experience in wartime and in the post-war scenario. Thus, the topic itself raises ethical challenges and sensitivity. My field interaction, experience, and relationship with my 
respondents also varied at multi-levels. In this section I produce a reflexive analysis of my positionality in the field including how I position myself and how I was positioned in various contexts; and also, how my positionality was shaped and reshaped throughout the research process. This constant reflexivity came into play at all stages of the project from researching the contact information of the respondents to entering the field. It also included my own stories which I shared with the women and whose stories I was keen to hear.

In the process of trying to contact women ex-combatants, I found that I was positioned by my identity. The women I interviewed interpreted me in various ways which sometimes led to cooperation but at other times increased the challenges. For example, before getting access to women ex-combatants I met a few gatekeepers and in a meeting one of them said to me, 'you are a woman...can you conduct such fieldwork in a rural area? You know you need to walk, and you are a city woman... and on the top of that ... you are living and studying in abroad...I can see your desire to travel to rural area could be difficult.' (conversation, December 2013, Kathmandu). At first this statement was challenging but then I could not deny the reality of the overtly patriarchal society in which I belong, its social norms, values, and rules. I was in an awkward situation, but without confronting the statement, I handled the remark very carefully. I shared with him my travel experience around the rural areas of Nepal while working in local non-governmental organisations, including research for my master's thesis. I also highlighted my $\mathrm{PhD}$ thesis objective. My response might have limited some prejudgements about me and reshaped my position. Later, this gatekeeper became quite cooperative in making contact with some of the respondents. Also, I must admit, the comment raised by the gatekeeper demonstrated how my gender, education and location intersected, and was interpreted by everyone I interviewed. Another learning point: whenever I contacted gatekeepers they would always ask for my last name because it would reflect my caste and belonging (thaar). Among many identities, caste became an important subject in this research, because as the caste system is socially and culturally practiced in Nepal, it can determine gender roles, relationships, public-private issues, social norms, and everyday life of the people which is profoundly influenced by their caste identity.

Being 'native' and interacting in the Nepali language made the interviews more lively and indepth. I was able to understand even the local slang, local festivals and marriage, religion, gestures, and common history. This gave cultural and contextual meaning to the topic and 
enabled me to become an insider. But in other regards I was different, due to my caste, upbringing, and education level which shape me as an outsider in some situations.

However, despite of my 'outsider' characteristics, I tried to position myself by 'becoming local' and searched for common ground to blend in with the setting. In this vein, for one month I built strong relationships and trust with these women and their families. For instance, I became a part of their everyday lives like their neighbour rather an as a researcher (I did not start interviewing immediately). I went with them to the field and helped them doing harvesting, sometimes provided childcare, had afternoon tea together, went to the hair salon, attended local functions (marriage, worship, etc.) accompanied them to the markets, shared the same vehicle to travel to the local area, and went to meet some of the women's relatives who were living in Narayanghat (Chitwan). In this way, we exchanged food items; sometimes they would come to ask for oil, milk, or vegetables etc. and a few times I went to ask from them. I also supported their kids while they did their homework. I positioned myself in a sisterhood relationship with my respondents. A few named me 'naya didi' (new sister) and some called me 'baini' (younger sister). I developed sisterhood relationship. Although sometimes the subjects were not related to my study, my emotions and feelings were affected. For example, one of the women had a miscarriage and she needed blood immediately, so I helped her all the way in this situation.

Apart from any other identity, my gender as a female also challenged the research process very often. When I was introduced to women and their families, they asked me in a surprised way, 'As you are a woman, will your family allow you to stay away for such a long time? Who will take care of your child or family members? Who will do your household work in your absence? Are you not afraid to live alone?' I wonder if such questions would be raised with a male researcher doing the same study. Nevertheless, I answered their queries and later I shared with them my personal history, commitment to the subject of gender, women, war and post-conflict issues, including my experience of travelling to various Maoist cantonment sites to interview women ex-combatants for my master's study. My willingness to answer questions and speak openly convinced them of my real interest in this topic.

During the course of conversation, some women asked, 'Are we giving interview correctly (in Nepali language bhanneko thik cha)' They also said, 'We are uneducated women and might not know how to define things or speak in a proper way so therefore correct us if we are wrong'. Here, my identity as an educated $\mathrm{PhD}$ researcher played a role in positioning me as the one with power over the process. In order to retain a collaborative and parallel power relationship, 
I emphasized the importance of their knowledge and experience. I said, 'your field-based knowledge in the context of war and post-war in wider than mine...therefore, I have come to learn from you'. This statement helped the conversation progress in the interview.

Maintaining confidentiality was an important ethical consideration. This was a core aspect of this study and this promise made women more likely to participate fully in the interview process. As the study was about war and the post-war context, women's stories involved many forms of violence, including life in prison, the pain of family separation, the pain of missing the family members, encountering violence and death of loved ones, and the challenges of becoming a widow. All of these stories were emotional and heart-rending and a few times I cried with them. These emotions were so deep and due to my 'positionality' as their 'new sister' or 'younger sister' they felt comfortable sharing them. Moreover, as interviews were unstructured, and the confidentiality was assured, the women felt comfortable giving voice to what they felt was important including stories of violence.

Misinterpretation of the researcher-researched conversation posed a challenge to my position. Women were involved in my research, but their husbands or male family members were not. However, men were living in the community and clearly understood that I was undertaking this project. In one of the focus group discussions about women's rights in post-conflict, one male member interrupted the conversation and started giving his own views. He said, 'Now women in Nepal...have been given more rights than they need, it's more than enough,' He pointed at me and said, '... see you have full right that's why you are here... nowadays women get good food to eat, spend money, talk openly, what else now do women want'. I felt very offended about the way he reacted, but I stayed calm, and thought the man might have mis-interpreted me and my research. I talked with him together with other women, where we explained what we mean by women's rights in the post-conflict period and, with the women's support, we were able to reconstruct the conversation.

Similarly, to maintain my 'positionality' in the field, I kept my political views neutral. My research subjects were a politically active group and many times they questioned my political opinions, but I remained silent. Whenever women raised their experience about political issues, I refrained from expressing my opinions because I wanted to maintain my 'neutrality' and avoid mis-interpretation that could negatively impact my research. 


\subsection{Ethical Considerations}

While doing this research I committed to being ethnically responsible.

\section{Informed Consent}

Before I started interviews, I explained to all of my respondents and gate keepers (Maoist leaders, local NGO, and local leaders) about the aim of this study. At the same time, I described my personal life: family background, experience working on women's issues, and my current situation. Also, I described clearly that the purpose of my study is purely academic. However, in the initial meeting with Maoist leaders in Kathmandu, several of them assumed I was a journalist and hesitated in providing women's contact details but when I explained about my work the leaders cooperated with me.

\section{Do no Harm}

I aim to avoid actions which would harm people directly or indirectly. In the interview process, non-hierarchical relationships (between researched-researcher) were maintained by providing the opportunity to choose the topic and lead the discussion. The following were important: not using English slang or raising questions that could create discomfort, respecting their voices, emotions, and feelings, making clear possible mis-interpretations, seeking cooperation and collaboration, searching for common ground, and respecting the local culture, food, religion, customs and languages.

\section{Confidentiality}

Prior to any interview, I informed respondents about confidentiality. This is a core element in this study. Also, to maintain the confidence of the women, the names used are pseudonyms. Other information which they felt discomfort to share publicly was also disguised. 


\subsection{Data Management and Analysis}

I collected a significant amount of quite varied material during the one-year period of fieldwork from January 2014 till February 2015. This was an iterative process with themes emerging from the material. Ultimately, I used an iterative data analysis process to respond to the various opportunities that presented themselves for data collection in the field. This was a timeconsuming process with many different potential themes emerging from the material I had collected. Therefore, initially, I prepared a thesis outline based on the following chapter topics: gender role transformation, reintegration of the women ex-combatants, gender ideology, women's empowerment, gender inequality at the time of the earthquake. I then discussed the outline with my supervisors, re-arranged it, and prepared four sub-questions, drawing on the main question of the thesis.

With the women's consent, I recorded all the interviews in Nepali, and later translated them into English. A qualitative tool, Atlas ti. was used to arrange the data. Some interviews were very long so new projects under a theme where created using Atlas ti. and audio files were uploaded. Later, from these files, free and open codes were generated. Doing this helped to deepen understanding of the given topics and reach the findings. In the same way from the transcribed interviews quotations were extracted and highlighted in the manuscripts. 


\subsection{References}

Central Bureau of Statistics, Nepal. (2012). National Population and Housing Census 2011. Government of Nepal, National Planning Commission Secretariat, Kathmandu.

Fonow, M. M., \& Cook, A. J. (1991). Beyond Methodology: Feminist Scholarship as lived Research. Indiana University Press.

Greeen, J., \& Thorogood, N. (2009). Qualitative Method for Health Research (2nd ed.). London: Sage.

Hastrup, K., \& Hervik, P. (1994). Social Experience and Anthropological Knowledge. In K. Hastrup \& P. Hervik (Eds.), "Introduction” (pp. 1-13).

Housing Recovery and Reconstruction Platform-Nepal (2016) Community Participation in Rebuilding Bungamati after the earthquake of April 2015.

International Crisis Group. (2003). Nepal: Back to the Gun. Asia Briefing, Kathmandu, Brussels.

Legard, R., Keegan, J., \& Ward, W. (2003). In-depth Interviews. In J. Ritchie \& J. Lewis (Eds.), Qualitative research practice : a guide for social science students and researchers (p. 138). 0761971092.

Muzzini, E., and G. Aparicio. (2013). Urban Growth and Spatial Transition in Nepal: An Initial Assessment, Directions in Development, World Bank,

Washington D. C.

Ramazanoglu, C., \& Holland, J. (2002). Feminist Methodological Challanges and Choices. Great Britain: Cromwell Press Ltd.

Savin-Baden, M., \& Howell Major, C. (2013). Qualitative Reserach: The Essential Guide to Theory and Practice. Alingon, UK: Routledge.

Tremblay, M.-A. (1957). The Key Informant Technique: A Nonethnographic Application. American Anthropologist, 59(4), 688-701.

Van der Haar, G., Heijmans, A., \& Hilhorst, T. (2013). Interactive research and the construction of knowledge in conflict-affected settings. Disasters, 37, 20-35.

Suwal, B. R. (2014), Internal Migration in Nepal. Population Monograph: Economic Demography, vol. I, chap. 10, pp. 241-284, Central Bureau of Statistics, Government of Nepal, Kathmandu.

UNDP (2008) Chitwan District: Distribution of Caste and Ethnic Groups. 
UNESCO. (2015, August 15). Kathmandu Valley. World Heritage Convention. Retrieved on 20 September 2018, from: http://whc.unesco.org/en/list/121. on.

Zahle, J. (2012). Practical Knowledge and Participant Observation Practical Knowledge and Participant Observation. Inquiry, 3923. https://doi.org/10.1080/0020174X.2012.643626 


\section{Chapter 3: Changing Gender Role: Women's Livelihoods, Conflict and Post-Conflict Security in Nepal}

This chapter has been published in Journal of Asian Security and International Affairs. To cite this article:

Luna K.C., Gemma Van Der Haar and Dorothea Hilhorst. 2017. "Changing Gender Role: Women's Livelihoods, Conflict and Post-Conflict Security in Nepal.” 4 (2): 175-95. doi:10.1177/2347797017710743.

The chapter is slightly revised in this thesis. 


\begin{abstract}
This article examines how the Maoist conflict in Nepal affected women ex-combatants and non-combatants, looking at shifts in gender roles during and after the conflict particularly from the standpoint of current livelihood challenges. We argue that changing gender roles largely depend upon everyday practice of gender division of labour and power as it evolved during and after the conflict. We also found the conflict had different and contradictory effects: Both categories of women experienced a shift in gender roles, with women taking on tasks earlier reserved for men, but this effect was strongest amongst ex-combatants during the conflict. In the aftermath of conflict, these changes were partly reversed, and ex-combatant women in particular faced severe challenges to their livelihood and they often returned to traditional gender roles. The article also considers how women experience state and non-state responses meant to improve their economic security in the post-conflict setting. The paper is based on indepth fieldwork in Chitwan and Kathmandu district of Nepal. It draws on interviews with women ex-combatants/non-combatants and key informant interviews.
\end{abstract}

Keywords : Gender Roles, Women Ex-Combatants, Women Non-Combatants, Maoist Conflict, Post-Conflict Nepal 


\subsection{Introduction}

When women and girls around the globe join an armed conflict as combatants, they often break traditional gender norms and take up new roles and responsibilities earlier reserved for men, as they enter what is broadly accepted as a men's arena (Shekhawat 2015). Also, non-combatant women tend to face a shift in gender roles due to military and political conflict. When men are away on military duty or involved in rebel groups, or where husbands or fathers or sons are killed or disabled, the economic responsibilities which were previously fulfilled by men are disproportionately shifted to the shoulders of women (Arostegui 2013). There has been much academic debate whether conflict induced change in gender roles means that women are better positioned in the aftermath of war or whether women encounter new forms of insecurities. Authors have identified a diversity of gender effects of war and its aftermath. El-Bushra 's (2003) field research carried out in Sudan, Somalia, Uganda, Mali, and Angola indicates that new economic responsibilities and greater public presence of women induced by conflict may imply a (limited) shift in gender roles that to some degree carries over into the post-war period. Denov and Richard-Guay (2013) argue that reproductive roles and power relations during and after conflict are embedded within broader gendered power structures that shape gender identity and are unlikely to shift unless these structures change. Moosa et al. (2013) suggest that pre-war gender differences in rights and entitlements impact post war situations, rather than temporal changes during wartime.

Current work on armed conflict and gender have suggested that warfare may be a process that empowers women through various transitions over time (Arostegui 2013; Buvinic et al. 2012; Grabska 2013). However, the degree to which this is the case and the mechanisms at work are not yet well understood and might be very different for women ex-combatants and women noncombatants. To understand this process, we studied Maoist armed conflict and the post conflict context of Nepal. The paper aims to contribute to the ongoing debate on gender and war by offering a differentiated analysis of the experiences of both women ex-combatants and noncombatants on shifts in gender roles during the Maoist conflict and how that shapes their positions in the post-conflict condition in Nepal.

This paper investigates how the Maoist conflict in Nepal affected women, both ex-combatant and non-combatant (including war widows and women heads of households) differently. It looks at shifts in gender roles and livelihoods during and after conflict and asks how women 
experience state and non-state responses concerning their current livelihoods security. The article traces how the labour and livelihoods endeavours for women as well as their power positions have evolved in time. The paper further elucidates how post conflict programs in Nepal have systematically marginalised some categories of women despite their focus on gender mainstreaming. The paper further provides critical insights on how livelihoods insecurity for women in Nepal is intrinsically linked to not just the question of gender but also to caste and ethnicity.

The article starts with an introduction followed by conceptual framework, research methodology, findings and conclusion. The findings of the paper have been presented under two main headings: gender division of labour and power, and experiences of women excombatants and non-combatants during Maoist conflict and post-conflict in Nepal.

\subsection{Conceptual Framework: Gender and Power}

Gender scholarship emerging during the late 1980's conceptualized female and male roles as socially constructed through gendered meaning and practices (cf. Bock 2006, p.4) and pointed to the nexus between gender and power (Radtke and Stam 1994, p.5). Similar issues have been raised in research emanating from the context of crisis recovery, disasters and conflict where women tend to lack opportunities due to practice of power in their everyday life (Connell 2011; Moser and Clark 2001). A significant body of literature on feminist studies, feminist transnational studies, and security studies have questioned how gender practices and power relations affect women's roles, relationships, victimization and capacity differently from men (Arostegui 2013; Mousa et al. 2013). Similarly, Cockburn (2013) suggested that women and men possess different roles, expectations of heroism, and fatality, and die different deaths during war and peace. The gendered lived experiences intersect with hierarchies of identities, such as caste, class and region, which call for multi-layered analysis of the category of gender itself (Crenshaw 1998). Power and labour in an analysis of gender allows us to see how gender is constructed through the practices of power and labour and how women and men at the micro level of everyday politics and social interaction regulate the practice of gender (Radtke \& Stam 1994; Connell 1987). This paper draws on the insights of gender role transformation, gender studies, feminist studies and intersectionality to analyse everyday lives of women in conflict affected areas and to explore what their lived experiences tell us about the nexus of gender and power in Nepal. 
We build our definition of 'gender and power' upon Connell's (1987) conceptual framework which argues that gender is socially constructed and flexible and can be understood in terms of the structures of 'labour' and 'power' (p.91-111). Connell suggests that due to the division of labour and power structures the gender relationships, gender roles, and gender orders are constructed and re-constructed in the societal context (ibid). She offers the following framework to understand this process: i) the sexual division of labour which describes gendered labour practices and differences in 'women/men's work' 'pay', 'positions' 'households' jobs' and 'public jobs'(private/public), and (ii) the division of power structures which is about authority, control and coercion and the hierarchies of institutions, domestic authority, sexual regulation and surveillance, and its contestation. She writes that power is relational and is a process of domination and resistance. At societal level, the labour and power are embedded through historical norms, family, class, religion, and other socio-political forces (Connell 1987, p 95-104).

Connell describes the practice of labour, such as the organisation of house work, childcare, paid and unpaid work, men's jobs, women's job, discrimination in promotion, unequal wages and exchange (Connell 1987, p.97). The practice of power, for example, through the hierarchy of institutions, domestic authority, sexual regulation and surveillance (ibid). Applying Connell's framework allowed us to explore how labour and power are practiced during and after the conflict, and how this affects gender role change and livelihoods security of women in their daily lives.

\subsection{Gender and Women Situation in Nepal: A Historical and Political Context}

Historically, women in Nepal have suffered from gender, caste, ethnicity and regional based inequality (Acharya 2006; Manchanda 2004), which is reflected in women's participation in the economic social, health, education and political sectors at all levels (Åshild 2010). Women have a subordinate position in Nepalese society, either subjected to their father or their husband, and their roles tend to be confined to the domestic sphere (Acharya 2006). Prevalence of girl child marriages, preference for sons and polygamy are some of the factors which limit women within the domestic sector (ibid). Women's expectations to gain full citizenship right in recent Constitution 2015 remains unfulfilled because new Constitution only allows Nepalese women to confer citizenship to her child if she proves that the father is not a foreigner and the child was born in Nepal, and in case of woman married to a foreign man can confer only 
naturalised citizenship to her child, whereas for a Nepalese man these clauses does not apply (Malla 2015). Since decades, Nepal is facing diversity in poverty because one category of caste (Bahun and Chettri) class (upper class), and gender are more powerful to another with large access to resources, among them men occupy superior positions to women. Such a historical construction of gender norms and roles results women to undergo diverse poverty and unequal development outcomes in Nepal (ADB 2010). In addition, rural women from certain caste and ethnic groups (particularly dalit, janjati, madeshi, tharu) experience larger exclusion because the State and non-State actors ignored to include right, needs and issues of these group in the mainstream of Development (Nepal NGO Coalition 2010).

There was a major political shift in Nepal during 1996 as the Maoist party of Nepal started the People's war with an objective to end structural inequalities (Briggs 2015) based on gender, caste, class, ethnicity and region, and to abolish the monarchy that lasted for 250 years (Manchanda 2001). Between 1996 and 2006, the conflict caused great political, social and economic turmoil that led to 13,000 fatalities and 200,000 being internally displaced (Ariño 2008). The Government of Nepal and the Maoist party signed a Comprehensive Peace Accord on 21 November 2006; since then Nepal has formally been in a post-conflict peace building phase (ibid).

The Maoist conflict affected Nepalese women in various ways. Many, especially in the rural areas, suffered from fear of insurgent reprisal, gender-based and sexual violence and increasing vulnerability as husbands or fathers were killed or out-migrated (International Centre for Transitional Justice 2010). However, the conflict also allowed women to take on social and economic duties previously reserved for men (Bhadra and Shah 2007). Non-combatant women took up roles formerly performed by their absent husbands both in the domestic sphere and to a certain degree in the public sphere. Shifts in gender roles were even stronger for women who joined the Maoist army. Female participation in the insurgency was without precedent in Nepal. Nearly 30-40 per cent of the Maoist combatants were women taking up guerrilla roles (Ariño 2008; Tamang 2009). But after the war ended, some women ex-combatants faced stigmatization while returning home (K.C. 2011; Valente 2011). The 'gender dividend' of war was not straightforward and both ex-combatant and non-combatant women faced severe limitations in building up livelihoods. 
To recognise the gendered challenges in post-conflict reconstruction and to promote women's participation in the public sphere, there have been some reconstruction programs in Nepal. The 2015 Constitution extends affirmative action and the rights of women, dalits, indigenous and other minorities. Independent constitutional commissions are provided for women and the Dalit, Janjati, Madhesi, Tharu and Muslim communities. The Human Rights Commission has been given the mandate to recommend reforms to laws, policies and practices to end discrimination (Mahat 2015). Government and non-governmental agencies have worked to ensure the participation of women from various caste groups in electoral processes and in government through a variety of programs (Dahal and Bhatta 2008; Ramnarain 2015). To further the aims set out by the Beijing World Conference 1995, there have also been endeavours to mainstream women's issues in Nepal's development agenda. All these have been done in tandem with the United Nation Security Council Resolution (UNSCR) 1325 on Women, Peace and Security, which supports local women's efforts in building sustainable peace. These attempts have also been made to foreground indigenous processes based on equitable distribution of social, economic and political power (Dahal and Bhatta 2008). The Nepalese Ministry of Peace and Reconstruction is also working to engage women's organizations from different caste and ethnic groups in peace-building and reconstruction programmes in Nepal (ibid).

\subsection{Research Methodology}

The study selected woman ex-combatants and non-combatant heads of households (in charge of socio-economic chores in the absence of the men during the war, including war widows). The central method of the paper is ethnography; Author 1 stayed in the field for more than a year in 2014-2015 and conducted in-depth interviews at different intervals of time with twentyfive women ex-combatants and twenty women non-combatants, six focus group discussions and a range of key informant interviews. The research was conducted in Padampur and Jutpani villages in Chitwan district of Nepal, which were highly impacted by Maoist conflict and comprised of diverse caste and ethnic groups; such as Tharu (indigenous group), Magar (ethnic group), Gurung (ethnic group), Limbu (ethnic group), Rai, Bhahun (so-called upper-caste), Chettri ${ }^{7}$, Tamang (ethnic minority), Madhesi (ethnic group),, Dalit ${ }^{8}$ and Newar (ethnic group).

\footnotetext{
${ }^{7}$ Upper caste in Nepal

${ }^{8}$ Considered untouchable caste in Nepalese society, though the Constitution of Nepal prohibits this practice.
} 
The authors also conducted interviews with dalit ten men ex-combatants and five noncombatants to assess their everyday experience on gender roles and relationship during and after the Maoist war. This allowed us to integrate male standpoints. Interviews were conducted in different areas of Kathmandu. Women and men are quoted by their surnames as it represents their caste and ethnic identity, which is an important element for analysis. The paper does not intend to represent any individual women and men ex-combatants or non-combatants but draws upon their narratives to contribute to the debate on gender in conflict and post-conflict contexts.

\subsection{Gender Division of Labour and Power: Experience of Women Ex-combatants and Non-Combatants during Maoist Conflict in Nepal}

Connecting with Connell's (1987) theory this section of the paper first examines the gender division of labour during the Maoist conflict for both categories of women who experienced shifts in gender roles due to the conflict and took up roles formerly reserved for men. It then turns to the question of gender division of labour and power at the same period in Nepal.

\subsubsection{Women Ex-Combatants: Experiencing Gender Equality}

\section{Gender Division of Labour}

This section illustrates gender division of labour during the Maoist conflict based on in-depth study conducted with women ex-combatants and some of the men ex-combatants. Issues discussed in the interviews were how the works were distributed among them and how the practice of gender took place in their everyday lives. The Maoist movement had a stated agenda on gender equality that, as we found, was translated into the daily organization of the insurgency. Both women and men shared that they held positions related to combat, for example, brigade commanders, platoon commanders, section commander, leading the formation, giving training, fighting and carrying the guns/bullets. In addition, both women and men performed service-oriented tasks, such as providing health care; working in the cafeteria as cooks and cleaners; acting as messengers; running, climbing trees, carrying wooden logs; participating in sentry duty; performed hard military trainings, getting involved in construction work; and organizing cultural programmes etc. 
The majority of the interviewed women ex-combatants and men ex-combatants stressed the contrast between the clearly defined gender roles they had been used to and the policy of gender equality within the Maoist movement. The following quote illustrate that:

During the Maoist war, I [and] all the women ex-combatants performed male roles, which are reserved for men in our society. I did military training, took part in decision making, speaking infront of the groups with confidence, taking up the leadership roles, climbing the trees, digging the ditches based on rotations. Similarly, men also did the cooking, cutting vegetables, washing, and cleaning jobs at that time. (Tamang woman ex-combatant, focus group discussion in July 2014, Chitwan).

The Maoist movement also claimed to erase ethnic and caste discrimination; for instance, during the time of war, large number of women were mobilized from the excluded castes such as ethnic indigenous and Dalit groups. These groups of women wanted to uphold their rights and seek social justice. The Maoist movement strengthened the level of awareness of these groups and empowered them by providing them skills training. The following quotes illustrate this point:

I am a Dalit woman, during the war I performed all types of work given to me such as construction work, leading the battalion, decision making, running, or climbing trees. I was not discriminated for holding Dalit identity in the Maoist group. (Dalit woman ex-combatant, interviewed in February, 2014, Chitwan).

Our study demonstrates that during the Maoist conflict in Nepal, women ex-combatants were liberated from traditional gender roles and empowered to take on new roles traditionally reserved for men, which was unprecedented in the Nepalese context. While looking in this context, we learned that the Nepalese women ex-combatants received room for manoeuvre to stretch their gender roles and higher degree of gender equality during the war, which made them capable to internalize that women spheres are unlimited when they get exposures in public domain. Most importantly, our findings from the case study of Dalit women ex-combatants raise an attention in the feminist debate that gender should not be the only axis of analysis, rather ethnicity, class, caste, location should be considered to identify differences among women. 


\section{The Gender Division of Power}

This section identifies and analyses women and men ex-combatants' experiences of division of power, and the way they accepted and mobilized it in their everyday lives during the Maoist insurgency. Power was internalized by women ex-combatants since both women and men participated equally in decision making and negotiating within the Maoist party at all levels, had the ability to overcome difficult situations and influenced the political and economic decisions of the party.

A majority of women and men ex-combatants shared that they experienced an equal division of power in their lives during the war; for example, some women actively participated in decision making and their contributions were acknowledged by the Maoist party by offering them higher ranks. Some other women combatants were involved in designing, planning and monitoring activities of the battalion and participated in economic decisions. During the discussion, women ex-combatants shared that they were accurate and reliable in planning and monitoring combat activities. The following quotes provide evidence of this:

I was in the platoon led by woman commander, she was very brave, and made wise decisions of the Maoist party. I did not find any difference in her leadership compared with other men commanders. (Chettri man ex-combatant, interviewed in March 2014, Chitwan).

I was a company commander, I provided training, and headed the management and decision making of my battalions. (Magar woman commander, interviewed in April 2014, Chitwan).

The above findings illustrate that during the Maoist war, power as defined by the Maoists was organized and deployed equally among women and men combatants in such a way that both women and men had equal opportunities to access, deliver and practice power in their daily surroundings. The scholarly literature on conflict often portrays the image of women as victims of their armed groups; hence, before we conducted our fieldwork, we had a priori assumption that Nepalese women ex-combatants had been victimized by and suffered at the hands of the Maoists during the civil war. However, our findings from the fieldwork confirmed that the Maoists had shifted the traditional pattern of gender relations in Nepalese society by mobilizing and treating women and men equally during the civil war. Our conclusion contrasted with the findings of Denov and Gervais' (2007) study on the civil war in Sierra Leone, where women 
ex-combatants admitted to being victimized by their armed groups and feeling a sense of power while holding a gun as it symbolized a sense of victory over their victimization by their armed groups.

\subsubsection{Women Non-Combatants: Replacing Husbands and Fathers}

\section{Gender Division of Labour}

Women non-combatants, who did not join the Maoist movement, also experienced shifts in gender roles. In the villages, women had to cope without their husbands and fathers, many of whom were killed or out-migrated in search of economic opportunities or to escape from the war. Next to their domestic roles, these women started to take on the tasks previously performed by men, both in agricultural production as well as in the more public roles related to trade and local politics. Based on the in-depth interviews with women and men noncombatants, we constructed the gender division of labour during the conflict as follows:

- Women responsible for traditional roles such as taking care of the kids, preparing and serving the meals, doing the laundry and washing dishes, taking and bringing back children from school and fetching water.

- New conflict-induced roles performed by women in the absence of men; for instance, bringing firewood from the forest, running small businesses like tea stalls, tailoring shops or restaurants, bringing food from the market, doing cultivation (own land or others) and taking care of livestock (chicken, cow, buffalo, goat).

- Women also took on social roles; they attended the festivals and feasts in the village, yet also found room to attend village meetings and participate in local politics.

The following quotes demonstrate these points:

After my husband was killed during the Maoist insurgency, I completely took responsibility of my two sons and my father and mother in-laws, the farm and households including making money for my family. I learned tailoring and started running my own small business. But I also took care of cattle and goats, bringing firewood, cooking food, looking after the children. (Magar widow, interviewed in July 2014, Chitwan). 
A migrant woman now living in Kathmandu, affiliated to a local NGO that implements women empowerment programs, shared:

My husband migrated to India to protect himself as he was suspected of being a Maoist and was under an army search list. During that time, I was left alone and came to Kathmandu, I learned driving tempo and earned my family livelihood through it. I am Chettri and in my caste women doing such jobs are not accepted and I faced many stigmas for being women driver and overcame the challenges. (Chettri woman non-combatant, interviewed in January 2015, Kathmandu).

My wife was very shy, she never went out of the village. I was affiliated with the Maoist party. Many times, the army raided my house suspecting me to be a spy, and later I went underground for about 6 years. During my absence, my wife looked after my 2 kids and my parents. She performed all the duties alone in the kitchen, farm, and outside; for instance, she runs a tailoring shop. (Maoist local leader, interviewed in November 2014, Chitwan).

From the above explanations, we learned that women non-combatants during the Maoist conflict had to undergo greater struggle as these group of women performed both the jobs at household level (taking care of kitchen and kids) and new roles in public affairs (earning, participating in trainings, affiliation with local organizations and local politics) previously fulfilled by male members of their family. Our findings highlight that the Maoist conflict not only changed the gender roles among women ex-combatants but also among women noncombatants, as can be seen through the experiences of the Chettri (upper caste) migrant woman who accepted the tempo driver's job and a Magar widow who solely took the economic responsibility of her family and ran a tailoring shop. This was a very rare social practice in Nepal before the Maoist war. Our study also confirms the view that conflict transforms gender roles to some degree, enabling women to construct independent resistance and resilience to face the altered realities of their daily lives, something they would never have experienced in the presence of men under normal circumstances.

\section{Gender Division of Power}

In the interviews conducted, the women non-combatants identified power as the ability of women to make decisions within their households and communities; networking and 
negotiating; accessing and exercising control over assets; having opportunities to join politics; and setting up businesses and participating in meetings. The following story of a woman noncombatant illustrates these points:

I married to a Bahun man, but I belong to the Tamang ethnic group. After I became a widow my husband's family did not give me place to live nor did they look after my children. My husband's parents and brothers were also unwilling to give me the portion of land, which was the share of my husband. Later with the help of the local organization that provided legal advice I filed a case against them and decision of the local court was in my favour. I was afraid thinking that they would take revenge for what I did. (Tamang widow, interviewed in April 2014, Chitwan).

A majority of the women non-combatants who were interviewed shared that due to Nepal's patriarchal society the markets still remain masculine (dominated by men); hence, it is difficult for women who are not protected by the men. This can be seen from the experience of the Tamang widow above, who was denied rights to her dead husband's property by her in-laws and suffered from the fear of social prejudice and retribution. Some women non-combatants also shared that they faced stigmatization when they ran a business (driving, running shop and restaurants) as it is still considered a men's job. A few widows even concealed their identity to avoid certain evil practices that continue in some areas. For instance, widows face stigma while operating their businesses; they are often denied participation in social rituals and functions as they are projected as a 'symbol of impurity' (Yadav, 2016); they also face stigma if they decide to remarry; and they are discriminated against in trying to find jobs or to rent a house. This reflects how women as a widow, or as a business person, or as a mother require male presence in the community as a part of social gender order. Our study argues that despite of the presence of male supremacy in the Nepalese community, women non-combatants challenged the traditional gender norms and took the new gender roles to protect their identity and daily needs. However, at the same time, women in Nepal have become more aware and informed about their legal rights, mainly because of awareness and advocacy campaigns. Being more informed as well as being economically empowered, women can now offer greater resistance and establish more equitable gender roles and relationships in the society. 


\subsubsection{Comparing Women Ex-combatants and Non-Combatants: Gender Division of Labour and Power during Maoist Conflict in Nepal}

Looking into the gender division of labour between women ex-combatants and non-combatants during the Maoist conflict, we found that in the case of women ex-combatants the division of labour were equal which provided a forum to women to perform masculine roles by shifting their traditional roles and relationships. Women non-combatants performed both the duties in the domestic and public domains in the absence of their men. For both groups of women, gender roles changed but in a different way; one group of women were recruited as combatants as it was their motivation to join the war, but for women non-combatants there was no choice in their lives rather than accepting the reality of losing their male counterparts. Further, during the conflict, women ex-combatants performed jobs collectively on rotation basis between women and men, whereas in case of women non-combatants they did it all alone facing all the challenges of life.

While comparing the gender division of power and considering everyday practice of power in women's everyday lives, we found the following. In case of women ex-combatants during the conflict, the power division was equal. Women were provided opportunity equal to men and women even controlled the battalion where men were subordinate to them and accepted their leadership. Moreover, the decision-making process, party management and leadership positions were led equally by women based on their capacity and skills. Therefore, during the conflict, power was practiced collectively within groups. In the case of women noncombatants, however, they had to perform more tasks individually, taking up men's roles, and had to fight hard for their rights and livelihoods. The increase in the workload they experienced was not accompanied by a greater acknowledgement in society, and many women faced stigmatization, which complicated fulfilling their daily livelihood tasks. While women excombatants gained respect for the way they changed their roles, non-combatant women in the communities faced stigmatization and marginalization.

\subsection{Gender Division of Labour and Power: Experience of Women Ex-Combatants and Non-Combatants in Post-Conflict Nepal}

This section describes the gendered division of labour in the public and private sphere in the post conflict setting in the lives of women ex-combatants and non-combatants, and how this 
practice impacted their livelihoods differently. It also shows how some of the 'gains' for women, in terms of power, came under pressure after the conflict.

\subsubsection{Women Ex-Combatants: Re-Integration and (Re-) Marginalization}

\section{Gender Division of Labour}

Women ex-combatants experienced a strong shift from the conflict to the post-conflict period. After a lengthy period of demobilization (during which many of them spend several years in a cantonment), they returned to civilian life with a small sum to set up new livelihoods. Many of the women ex-combatant interviewed did not return to their regions of origin but settled instead near the cantonment areas. They now faced the hardships of managing household and searching for ways to generate an income for living.

A majority of the women ex-combatants shared that due to having small kids they invested most of their time at home; hence, many women ex-combatants created their livelihoods by rearing livestock, producing alcohol at home, selling firewood and sharecropping. It was surprising to note that only few women ex-combatants participated in the village-level meetings. However, for many of the women ex-combatants, livelihoods survival was largely dependent on social networks, their own agency and support from war peers. In many cases, women borrowed money from friends or neighbours, they also exchanged labour with their extended family to perform certain chores and some others invested in a business or trade together with their war peers. There are approximately 300 households of ex-combatants in the Padampur and Jutpani villages in the Chitwan district. The following stories explain how the gender division of labour changed from the war to the post-war situation:

I am married to a Dalit man, but Dalit are still considered untouchable in the community. My husband goes out in the search of work and I do all the household tasks. We both do not have formal education, so cannot find jobs. Specific training that we received during the war, such as hard exercise, formation, running, fighting, and leading the battalion, cannot be used now. (Limbu woman ex-combatant, interviewed in January 2015, Chitwan). 
I am a trainer of non-violent conflict. GIZ ${ }^{9}$ provided this training and now I travel to the villages and also to other districts to provide training to the people. My husband looks after my child and cook's food and takes care of the business. I also cook sometimes, but most of the time my husband does for me and my son. (Tamang woman ex-combatant, interviewed in July 2014, Chitwan).

Until now I participated in the kitchen garden training provided by GIZ, but I cannot utilize it as I do not have enough land to do the farming. My husband and I work together; mostly I do the households chores as my child is very small, and my husband does most of the outside jobs. We have a small shop where we sell the food items in the village, so my husband does all the shopping. (Bahun woman ex-combatant, interviewed in June 2014, Chitwan).

All of the women ex-combatants we approached got married outside of their caste. This was a major achievement of the Maoist movement, which accepted inter-caste marriages; but marriage with a dalit and getting that marriage socially accepted remains a big taboo. In some cases, we discovered that if a dalit man is married to a woman from a higher caste group such as bahun/chettri or other non-dalits, the woman is easily accepted by the man's family; but if the woman happened to be dalit and is married to a man from a higher caste group, in such a situation the woman is rejected by the man's family. This reflects caste-based gender discrimination, which applies to dalit women but not men.

The Maoist's primary conflict objective was to end all forms of discrimination in Nepal based on caste. However, while inter-caste marriages between various 'touchable' (non-dalit) caste groups, for example between Bahun and Newar are frequent and widely accepted, but the intercaste marriages between 'touchable' and 'untouchable' (dalit) caste group are still considered a taboo and are rarely accepted.

The majority of the women ex-combatants that we interviewed considered that the Government did not provide them with good training and job skills to get reintegrated properly into the community, which resulted in unemployment and suffering. Some of the organizations like GIZ in partnership with pro-public (a national NGO) did provide some training in tailoring,

\footnotetext{
${ }^{9}$ German Development Cooperation
} 
snack making, vegetable farming and so on, but it was not very useful due to the lack of land and demand for these training.

Within the household, the equal gender balance that women grew accustomed to during the Maoist conflict was largely maintained during the post-conflict period. Although the women ex-combatants mostly performed household jobs, the practice of gender equality within the household and in family decision making (such as pertaining to buying or selling of land or livestock, lending money, participating in training or going to a marriage ceremony) continued during the post-conflict phase. However, outside of the household, women had to confront more traditional ideas on the gender division of labour: for instance, majority of the women we interviewed felt that men still dominated the village, and in the market, men still hesitated to offer women masculine jobs like construction work, running the motorbike workshop, driving and electronics repairing-jobs in these sectors were still mostly covered by men.

The above findings reveal how gendered division of labour is performed in everyday lives of women ex-combatants in the public and private spheres, and how this helps to create their livelihoods in the post-conflict context. While gender relations in the private sphere, between man and wife, continued mostly as constructed during the Maoist insurgency, in the public sphere, especially related to employment, women were confined to traditional roles and the 'gender divide' of the war did not carry over into the post-war setting. The study also indicates that the failure of the government to respond to the needs of women-combatants created a sense of isolation and limited women's mobility in the public sphere. For example, many women excombatants missed school as they had joined the Maoist movement at an early age; this lack of formal education became a handicap for them in the post-conflict phase since even some of the lowest level jobs required formal education. Moreover, the lack of appropriate skills and job training for ex-combatants and inadequate government investment in employment made the post-conflict condition difficult for women ex-combatants.

The paradox of the Maoist conflict for women ex-combatants was that while the conflict mobilised and empowered them, after the conflict ended, they had to live in isolation. The skills they had learned during the conflict were not particularly useful for the labour market. Hence, many women ex-combatants had to return to their traditional gender roles limited to their household regimes. Especially women with small children were more confined to domestic tasks, as it is difficult for them to work with young children at home. This research found that 
only one-woman ex-combatant who got affiliation with GIZ was able to maintain herself by going out for part-time work as a trainer. Our main conclusion then is that while the Maoist conflict has brought about transformation in the labour and power structures at the household and individual levels, it has not done so at the societal level. Therefore, it is still difficult to remove entrenched patriarchal practices at all levels of society.

Furthermore, these findings raise an important question: to what extent are women able to have 'meaningful lives' in post-conflict Nepal? In this context, Manchanda (2004, p238), in her paper on the women movement and Maoist insurgency in Nepal, has observed that:

In South Asia, both nation state-building projects and armed revolutionary class struggles have seen the mobilization of women and its corollary, the subsuming of the women's question in nationalist or socialist projects and ideological strictures that in the aftermath pull women back to the gender discriminatory regimes of the personal sphere.

\section{Gender Division of Power}

The following section provides empirical evidence on gendered division of power in the daily lives of women ex-combatants to elaborate how the practice of power impacts their livelihoods. Based on discussions with women ex-combatants, this study categorized power as the following: process of decision making within the household and community; mobilizing resources; having access to assets (land, jobs, business, opportunities); negotiating; involvement in local politics; and social networking and agency.

Most Maoist women ex-combatants shared the household jobs, which are concentrated to domestic spheres in contrast to the roles that they performed in the war. In addition, they also shared that this did not mean that they are powerless; they are still very courageous, can make things happen, speak with confidence and do not hesitate to perform male jobs. They further added that their way of life and ideas are very different compared to the other women in the village. They are now aware of their basic rights and are informed about most of the contemporary local and national issues. The following quotation is from an ethnic woman excombatant, who shared that she still feels confident in speaking and making decisions compared to the other women in the village: 
I am very confident to myself, I understand the woman needs, I can think wisely for the sake of my family good, and I am very much informed about local politics, when it comes to making decisions for the house, me and my husband mostly take decisions together. (Limbu women excombatant, interviewed in July 2014, Chitwan).

The case of women ex-combatants in relation to division of power in the aftermath of war reflects that though women felt more confident about their ability and personality, when it came to owning property rights, they generally failed despite having experienced gender equality during the Maoist war. This means that after the war, women have once again become economically dependent upon men for their everyday livelihoods; and if women came forward to claim property ownership, they risked their marital relationship and exposed themselves to social stigmatization. We learned from the women ex-combatants that they felt they would carry more power and choice in the post-conflict phase if they were provided better reintegration packages including access to formal schooling, availability of micro-credit schemes and opportunities for training and skills development. The study conducted by Mazurana and McKay (2004) in Northern Uganda, Sierra Leone and Mozambique revealed a similar pattern, where girl combatants complained that they would carry more power and choice during the post-conflict phase if they were provided formal schooling, micro-credit to start a small business and skills training and development.

\subsubsection{Women Non-Combatants: Maintaining Economic Independence}

\section{Gender Division of Labour}

The women non-combatants continued performing jobs both in private and public domain in the aftermath of war. Especially women who became widows have had to take all the responsibilities of their family. For women, whose husbands came back after the war, the men did not find immediate jobs in the current market mainly because of being away for a long time and because of the lack of proper skills and education. Most of these men helped in running their wife's business. They also did kitchen and household jobs, unlike before the conflict. The following are voices from women non-combatants about their experience:

After my husband died in the Maoist war, I came to Kathmandu, where I am taking care of two sons. I run a tailoring shop. I do work, both at home and at the market. I am also a member of cooperatives, a religious network and a women's group so I go there some time 
every month. I also participated in the bookkeeping and financial training provided by a local community-based organization. (Bahun widow non-combatant, interviewed in August 2014, Kathmandu).

Right now, I operate a small restaurant in the Kathmandu Kapan area. My shop is located near school and college and the business is going well. After the end of conflict my husband returned from India, now we work together in this business. My husband does vegetable cutting, cooking and also serving the food for the customers. The restaurant is registered in my name. (Magar migrant woman non-combatant, interviewed in October 2014, Kathmandu).

Our study reveals that in the post-conflict phase, women non-combatants are doing their own earnings and are economically independent. They earn their own income in the public sphere; that is, by operating a business, plying a trade like running a restaurant or a food stall and attending meetings and entering politics. In the absence of their husband during the war, they had participated in life skill trainings, conducted business, made decisions and managed their livelihood. Therefore, they now know how to face the problems in life and that women can also do tasks that are reserved for men. Before the Maoist war, women were never invited to the meetings, did not take part in cooperatives and financial institutions and were not given space in decision making within the household. Women worked in the kitchen from dawn until dusk. The Maoist war provided women a level of awareness and now people cannot underestimate women anymore. Social networking and agency are another important aspect of women's independent livelihood; for instance, local-level family, relatives and friends' networks as well as peer groups provide useful channels for borrowing money, arranging childcare and sharing of problems.

Our study also finds that the Maoist movement led women non-combatants (widows, single women and women-headed households) to search for diversified livelihood options. In the absence of men, women had to re-negotiate their roles to establish their position in the community. Therefore, even in the aftermath of conflict, they continued their roles in the public sphere. Women were obliged to make decisions in the absence of men. They formed informal institutions such as working groups to foster small entrepreneurial activities. These groups provide women access to information and informal political power. Some aid organizations tried to further challenge the existing gender regime by offering women training in 'masculine' occupations, such as driving. While women were proud to be able to perform tasks traditionally 
considered masculine, such training is often unconnected to employment prospects in the real world.

\section{Gender Division of Power}

The majority of women non-combatants did not find much difference in the practice of power in the post-conflict situation, because of their economic independence. The quotes below are their illustrative:

I am a president of the cooperative and also got affiliated with many organizations. My husband is back after being underground for many years during war. I do all the public related jobs, and my husband looks after the farm, cattle, and other household issues as This is because since the beginning when my husband was not in the village during the Maoist war, I performed all the duties at home and also outside. So now people believe in me, so for the small matters they come to me and ask for help. (President of coperative, women non-ccombatant, interviewed in May 2014, Chitwan).

My husband disappeared during the Maoist War. I am solely taking care of my four daughters. Now, I lead the house painting contracts at Narayanghat Bazar and I am also a sub-contractor. I did this job for 14 years, so locals now trust me and my job. (Half-widow, non-combatant, interviewed in November 2014, Chitwan).

All the men (husbands of women non-combatants) whom we met shared that in their absence during the conflict, women performed great jobs alone and this made them independent and powerful. One husband of a woman non-combatant shared: 'If women would have lost hope, our children would have died, and our families would have collapsed during the Maoist war'. Our study suggests that women non-combatants who experienced independence did so because the Maoist conflict enabled them to manage livelihoods and to maintain power relationships. Being with cooperatives and other local organizations provided women non-combatants recognition and sustained trust in the community. Women also emphasized the importance of proper training and market development to enable entrepreneurship. 


\subsubsection{Comparing Women Ex-combatants and Non-Combatants: Gender Division of Labour and Power in Post Conflict Nepal}

In this section, we compare women ex-combatants and non-combatants in terms of the practice of their labour and power in their daily lives in the post-conflict situation. The gender division of power of women ex-combatants changed after the conflict. During the conflict, women followed the norms, regulations, tasks and decisions as per the demand of the Maoist party collectively. However, after their demobilization they could not use their skills such as carrying guns or leading battalions. The lack of proper re-integration packages, opportunities and skills suitable in the post-conflict situation drove them to accept their previous roles from before the war. In many cases, women were more confined to the house as they now lived in a nuclear family and could not rely on grandparents to look after the children. In terms of their livelihoods, women ex-combatants are mainly limited to farm activities, rearing livestock or making local alcohol. Although women ex-combatants have taken up traditional roles, they have clear understandings of their rights, political agenda and need to maintain social networks.

In contrast, women non-combatants are doing both public and private sphere jobs such as looking after their children, running their households and maintaining their business. All of them have their own business and have turned into entrepreneurs. They have also applied diverse livelihood strategies to run their daily lives: grocery stores, clothing shops, eateries and noodles selling, fancy stores, cosmetics and stationary shops, photocopying shops and meat shops. Many of these women have taken loans from NGOs to start and run their businesses. However, in terms of owning assets such as land or house, only one woman had access to it.

\subsection{Conclusions}

This study suggests that during the Maoist conflict in Nepal gender division of labour amongst women ex-combatants was more equal than what people were used to in pre-conflict settings. In discourse and in practice, the Maoists sought to reduce discrimination based on gender, caste and ethnicity. Both men and women held important positions within the organization such as brigadier commander, platoon commander and section commander, and provided leadership in formation and training. Women and men combatants were provided equal opportunities to exercise power at all levels within the organization depending upon their capacity and skills, particularly in decision making, leadership and ideological commitment, planning and design 
and monitoring of war activities. During the conflict, women combatants' gender roles shifted to include roles previously reserved only for men, and they could occupy leadership positions. As for women non-combatants, they took sole responsibility of the household after their husband died, or disappeared, or migrated out of the region/country.

In the search for livelihood options, these non-combatant women faced many challenges but managed to develop their entrepreneurship and leadership skills. Therefore, gender roles, which were confined within households, transformed towards the public sphere when these women started operating restaurants and tailoring shops, conducting farming and selling vegetables in the local markets and getting involved in local NGOs and financial organizations.

With regards to gender division of labour in the post-conflict setting, the failure of the Nepal government to offer proper re-integration package that addressed the needs of women excombatants created a sense of isolation among these women and limited their mobility in the public sphere. In addition, lack of formal education and adequate employment opportunities were the key reasons why women ex-combatants resorted to traditional work in the postconflict scenario and became more dependent on their husband's income. In contrast, women non-combatants were mostly earning an independent income through their involvement in the public sphere, and thus did not have to depend on their husband's income.

Our study informs that women ex-combatants have faced re-marginalization with regards to gender division of power in the post-conflict context. This is due to masculine-oriented market and untransformed gender order of the society, which still demanded women to be in secondary position to men. Many of these women have had to depend upon their husband for income, which has limited their role of doing household chores and looking after livestock. In contrast, women non-combatants have created their own livelihoods without depending on others, although some of these women continue to experience domination by their husband's family, particularly while getting access to their husband's land or property. The study further reveals that for both ex-combatant and non-combatant women, social networking and agency are important channels through which they could renegotiate their gender roles to create independent livelihoods.

Another key finding of the study is that both men combatants who participated in the war and men non-combatants who stayed away from home during the war hold liberal views about 
women and their wives. In the post-conflict setting, these men usually perform household tasks and help their wives with cooking, cleaning, fetching water and looking after the kids. The role of men shifted during the conflict, and this trend continues in the post-conflict phase.

The article further finds that remarkably for non-combatant women, the Maoist war in Nepal triggered more positive changes to their gender roles compared to women ex-combatants, even though the latter experienced more transformational work during the conflict. While noncombatant women have consolidated their new position and have room to manoeuvre after the conflict, women ex-combatants have been driven to take up traditional roles. In terms of power in the post-conflict setting, we find that both ex-combatant and non- combatant women have strengthened their position in the private sphere where they encounter more equality between men and women. With regards to public power, we find non-combatant women more often taking up leadership roles in their communities. In society, at large, we find that the division of labour and power continues to be highly embedded and the war has not led to changes in mindsets and social structures. 


\subsection{References}

Acharya, M. (2006). Goal 3: Promote Gender Equality and Empower Women Achieving Millennium Development Goals: Challenges for Nepal , 15, 48-69. Nepal Rastra Bank. ADB, (2010). Overview of gender equality and social inclusion in Nepal. Mandaluyong City, Philippines: Asian Development Bank. Report. Retrieved 28 Feb 2017, goo.gl/2al2uG

Ariño, M. V. (2008). Nepal: A Gender View of the Armed Conflict and Peace Process,118).Quaderns de Construcció de Pau. Retrieved 28 Feb 2017, goo.gl/HuQ4Xd Arostegui, J. (2013). Gender, conflict, and peace-building: How conflict can catalyse positive change for women. Gender \& Development, 21(3), 533-549. doi:10.1080/13552074.2013846624

Åshild, F. (2010). Women's Political Participation and Influence in Post-Conflict Burundi and Nepal. Peace Research Institute Oslo (PRIO), Research Paper. Norway.

Bhadra, C., \& Shah, M. T. (2007). Nepal: Country Gender Profile: Final Report. Japanese Internaional Cooperation Agency (JICA), Nepal.

Bock, B. B. (2006). Introduction: Rural Gender Studies in North and South. Wallingford, CABI, $1-15$

Briggs, G. (2015). Book Review: Prashant Jha. 2014. Battles of the New Republic: A Contemporary History of Nepal. Journal of Asian Security and International Affairs. 2 (3), 343-346. doi: 10.1177/2347797015601920

Buvinic, M., Dasgupta M., Casabonne, U., Verwimp, P. (2012). Violent Conflict and Gender Inequality: An Overview. The World Bank Research Observer, 28(1), 110-138. doi: 10.1093/wbro/lks011

Chonody, J. M. and Siebert, D. C. (2008). Gender Differences in Depression: A Theoretical Examination of Power. Affilia, 23(4), 333-334. doi: $10.1177 / 0886109908323971$

Cockburn, C. (2013). War and security, women and gender: an overview of the issues. Gender \& Development, 21(3), 433-452. doi:10.1080/13552074.2013.846632

Connell, R. (1987). Gender and power: Society, the Person, and Sexual Politics. Stanford, CA: Stanford University Press.

Connell, R. (2011). Confronting equality: Gender, knowledge and global change. Sydney: Allen and Unwin. 
Crenshaw Williams, K. (1998). The Intersectionality of Race and Gender Discrimination. Paper presented at the Background Paper, Expert Group Meeting on Gender and Race Discrimination, Zagreb, Crotia.

Dahal, D. R., \& Bhatta, C. D. (2008). The relevance of local conflict resolution mechanisms for systemic conflict transformation in Nepal: Berghof Foundation for Peace Support. Retrieved 2 March 2017, goo.gl/PPxWm5

Denov, M., \& Gervais, C. (2007). Negotiating (In) security: agency, resistance, and resourcefulness among girls formerly associated with Sierra Leone's Revolutionary United Front. Signs. Journal of Women in Culture and Society, 32(4), 885-911. doi: $10.1086 / 512488$

Denov, M., \& Ricard-Guay, A. (2013). Girl soldiers: towards a gendered understanding of wartime recruitment, participation, and demobilisation. Gender \& Development, 21(3), 473-488. doi:10.1080/13552074.2013.846605

El-Bushra, J. (2003). Fused in combat: Gender relations and armed conflict, Development in Practice, (13)2-3, 252-265, doi:10.1080/096145203200007

Grabska, K. (2013). The return of displaced nuer in southern sudan: women becoming men? Development and Change, 44 (5), 1135-1157. doi: 10.1111/dech.12051.

International Center for Transitional Justice \& Advocacy Forum. (2010). Across the lines: The impact of nepal's conflict on women (pp. 1-101). Kathmandu: International Center for Transitional Justice (ICTJ) Nepal \& Advocacy Forum, Nepal. Retrieved 3 March 2017, from: https://www.ictj.org/sites/default/files/ICTJ-Nepal-Across-Lines2010English.pdf

Karki, A. \& Seddon, D., (2003). The People's War in Nepal: Left Perspectives. (eds). Adroit Publishers.Delhi.

K.C., L. (2011). Securing livelihood: reintegration of mother ex-combatants in post conflict Nepal. M.Sc.,Wageningen University, the Netherlands.

Mahat, R.S. (2015, September 29). Positive constitution. Republica, p. 1. Retrieved 19 February 2017, from: http://admin.myrepublica.com/opinion/story/28980/positiveconstitution.html

Malla, S. (2015, September 25). Women discrimination in citizenship rights in Nepal Current Constitution. Republica, p. 5. Retrieved 28 July 2017, from: http://www. myrepublica.com

Manchanda, R. (2001). Women, war and peace in South Asia: Beyond victimhood to agency. New Delhi: SAGE Publications Pvt. Limited. 
Manchanda, R. (2004). Maoist insurgency in Nepal radicalizing gendered narratives. Cultural Dynamics, 16 (2/3), 237-258. doi:10.1177/0921374004047750

McKay, S. \& Mazurana, D. (2004). Where are the girls? girls in fighting forces in Northern Uganda, Sierra Leone, and Mozambique: their lives during and after war. Rights \& Democracy (International Centre for Human Rights and Democratic Development) and Canadian International Development Agency (CIDA), 1-148. Canada.

Moosa, Z., Rahmani, M., \& Webster, L. (2013). From the private to the public sphere: new research on women's participation in peace-building. Gender \& Development, 21(3), 453-472. doi: 10.1080/13552074.2013.846585

Moser, C. N. O., \& Clark, F. (2001). Victims, Perpetrators Or Actors?: Gender, Armed Conflict and Political Violence. London: Zed Books.

Nepal NGO Coalition. (2010). Periodic Review on Human Rights. Working paper. Human Rights Council, 1-19. Nepal.

Radtke, H. L., \& Stam, H. J. (1994). Power/gender: Social relations in theory and practice. London: Sage Publication

Ramnarain, S. (2015). Universalized categories, dissonant realities: gendering postconflict reconstruction in Nepal. Gender, Place \& Culture, 22(9), 1305-1322. doi:10.1080/0966369X.2014.958062

Shekhawat, S. (2015). Women in conflict and peace making, in Shekhawat (eds.) female combatants in conflict and peace challenging gender in violence and post conflict reintergation (pp.1-17). Palgrave Macmillan

Tamang, S. (2009). The politics of conflict and difference or the difference of conflict in politics: the women's movement in Nepal. Feminist Review. (91), 61-80. Retrieved 3 March 2017, goo.gl/iXeiKS

Valente, C. (2011). What did the Maoists ever do for us? education and marriage of women exposed to civil conflict in Nepal: World Bank Policy Research Working Paper Series 5741. Retrieved 2 March 2017, http://elibrary.worldbank.org/doi/abs/10.1596/18139450-5741

Yadav, P. (2016). White Sari Transforming Widowhood in Nepal. Gender, Technology and Development. 20(1): 1-24. doi: 10.1177/0971852415618748. 


\section{Chapter 4: Living Maoist Gender Ideology: Experiences of Women Ex-Combatants in Nepal}

This chapter has been published in International Feminist Journal of Politics.

To cite this article:

Luna K.C. \& Gemma Van Der Haar. (2018). "Living Gender Ideology: Experiences of Women Ex-Combatants in Nepal.” doi:10.1080/14616742.2018.1521296. pp 1-20. 


\begin{abstract}
Studies of women's participation in civil conflict as armed combatants have attributed diverse motivations to such participation and examined the implications of participation for women's empowerment in the aftermath. The authors contribute to these studies through an in-depth analysis of female combatants' struggles for equality and empowerment during and after Nepal's decade-long Maoist conflict. Scholars have argued that the emphasis of Maoist ideology in Nepal on the emancipation of women and on ending gender discrimination attracted a large number of women to the cause. Based on narratives of Maoist female ex-combatants, the authors investigate women's engagement with Maoist ideology during and after the conflict. These narratives reveal that despite discourses of gender equality in Nepal's Maoist struggle, promises around gender equality remain unkept in the period after the war. A reintegration program has offered women ex-combatants few options and has pushed women back into traditional gender roles. Struggles continue in this terrain. Incorporating intersectionality, the paper highlights how women ex-combatants' gender identities intersect with caste and other social locations to produce diverse challenges for their lives.
\end{abstract}

Keywords: Maoist armed conflict, Gender ideology, Empowerment, Women Ex-Combatants, Post-Conflict Nepal 


\subsection{Introduction}

Women combatants were heavily involved during the decade of Maoist armed conflict in Nepal. Estimates suggest that women made up 30-40 percent of the total Maoist's combat force (Sharma and Prasai 2004; Gautam et al 2003). Why the Maoist movement attracted such high numbers of Nepalese women has been mostly attributed to the Maoist gender agenda and the prospects for women's empowerment. Some feminist readings contend that the Maoist movement afforded rural women an option to escape narrowly confined gender roles and the exploitation they experienced in their daily lives (Thapa 2003; Manchanda 2004; Goswami 2015). Similarly, it has been argued that women were attracted to what they understood as a struggle against women's oppression and discrimination based on gender, caste and class (Gautam et. al 2003; Manchanda 2004; Sharma and Prasain 2004). Some authors have suggested, however, that the Maoist gender ideology was mere rhetoric and did not imply real empowerment of women (Tamang 2009; Pettigrew and Shneiderman 2004). This explanation fails to explain why women would stay on in the movement, as many of them did. This paper traces women's motivations and experiences during and after the Maoist insurgency in Nepal.

Among studies that examine women and Maoist conflict in Nepal, little attention has been paid so far to women's own motivations and the role of ideological commitment. Research on this topic with any ethnographic detail has been rare. Did women have an ideological commitment from the start, or did they develop such commitment once they were part of the movement? How did this commitment resonate with more private ambitions? And what happened to women's ideological drive in the post-conflict period? Based on narratives of female excombatants, this paper shows how these women relate to the particular ideological positions of the Maoist movement and how they connect this to what they describe as women's empowerment. The women described the sense of empowerment they experienced in their own words as: 'mahila sasahktikaran' (women's empowerment), "where they could raise their voices" (awash uthaunne), "women's voices were represented" (mahilako awaj ko pratinidithyo) and "understanding women's grief" (mahila ko dukka bhujnne).

Zooming in on women's own narratives allows us to show how private experiences of oppression and discrimination gain significance in the broader Maoist ideological framing and to trace how women's appropriation of this ideology carries over into the post-conflict context. With this explicit focus on women as ideologically motivated actors, this paper aims to 
contribute to the significant body of comparative literature on women, gender and armed conflict that has shown that women are not just victims of violent conflict but active agents (Jacobs, Ruth, and Marchbank 2000; Moser and Clark 2001; Kampwirth 2002; Enloe 2004; Cockburn 2013). Using the perspective of intersectionality, the paper considers women's diverse experiences during the war and in the post-war setting (Ruwanpura and Humphries 2004; Ramnarain 2014). Women taking-up combatant roles are not a homogenous category. As we will show, differences in caste, ethnicity, and class shape their experiences both during the war and in its aftermath. This is one of the few studies that includes 'upper caste' women's perspectives.

\subsection{Background: Gender Discrimination and the Maoist Agenda}

Gender, caste and ethnic-based discrimination have been pervasive in Nepalese society (Regmi 2007). Women in particular suffer from all forms of discrimination (Parvati 2003; Tamang 2009; Yadav 2016 ). The position of a woman is contingent on her male family members; father, husband or other male head of the family (Regmi 2007). These practices are reflected through the Nepalese inheritance system, family relations, and patrilocal residence and patriarchal descent, all of which are further reinforced by the legal system (Dhungana 2014). Marriage plays a key role in a woman's lifetime because it determines her destiny and livelihood options (Dhungana 2014). Traditionally, Nepalese women and girls have been restricted to the domestic sphere and excluded from the decision making (Dahal 2015).

The central objective of what became known as 'the people's war', that lasted from 13 February 1996 to 21 November 2006, was to abolish the monarchy, in essence a feudal system, and establish a new democratic republic (Karki and Seddon 2003). The Maoists had a strong agenda of emancipation for the oppressed rural population, lower castes and women (Sharma and Prasain 2004). Women and men of all castes, classes, ethnic backgrounds and education levels joined the movement (Sharma and Prasain 2004; Manchanda 2004). Most sources agree that the majority of women who joined the Maoist movement were from so-called lower castes, and were economically, socially, politically and sexually exploited (Parvati 2003; Manchanda 2004). Less known is that 'upper caste' women also faced similar restrictions and even worse gender-based discrimination. 
Women's issues were central to the Maoist movement. The Maoist ideological manifesto, the so-called "40-points demand document" ${ }^{10}$ integrated strong messages on gender equality, especially reflected in points 19, 20 and 21:

19. Patriarchal exploitation and discrimination against women should be stopped, girls should be allowed to access paternal property as their brothers.

20. All racial exploitation and suppression should be stopped. Where ethnic communities are in the majority, they should be allowed to form their own autonomous governments.

21. Discrimination against downtrodden and backward people should be stopped. The system of untouchability should be eliminated. (Karki and Seddon 2003, p.185).

These three points epitomize the Maoist ideology, are closely interrelated, and show how Maoist ideology claims to desire an end to patriarchal, gender, caste ${ }^{11}$ and all other forms of discrimination.

The Maoist agenda on gender and caste/ethnic equality was communicated by means of mobilization on the ground, a key element of the Maoist strategy to gain support amongst the rural population (Lawoti and Pahari 2009). During village-level rallies, action was taken on justice for women: punishing rapists, wresting back the usurped land of single women, penalizing men for polygamy and prohibiting the sale of liquor as a way to prevent violence against women (Gautam, Banskota, and Manchanda 2001). Within Maoist propaganda, the jan adalats or 'people's courts' were lauded as upholding the rights of women on issues of social and domestic violence (Manchanda 2004, p.248). In addition, in the areas under their control, the Maoists offered various positions to women, as well as Dalit ${ }^{12}$, indigenous and representatives of other marginalized groups who previously had never been given the chance to take up political positions. This approach contributed to ending untouchability and discrimination issues (Lawoti and Pahari 2009). Due to the Maoist grassroots struggle, women

\footnotetext{
10 The '40 points demand' was submitted by the Communist Party of Nepal (Maoists) in 1990 to the Nepal government.

${ }^{11}$ The caste hierarchy is as follows: highest is Bahun, then Chhetri, then Baise, and finally Sudra, known as the 'untouchables'or 'Dalit'. Today, the caste system is prohibited by law in Nepal, but still exist in the practice.

12 Dalit refers to a group of people in Nepal; who are religiously, culturally, socially, economically and historically oppressed, excluded and treated as untouchable caste. They are also called paninachalne (water polluting) and acchut (untouchable). Any sort of contact from members of Dalit is unacceptable and contact with them requires a purification ritual.
} 
were increasingly visible in the public sphere, something that previously had been limited to educated women from one of a few strong political families (Yami 2010).

\subsection{Theoretical Framework}

\subsubsection{Gender, Women and Armed Conflict}

Globally, gender is increasingly being recognized as a fundamental issue in armed conflict (Enloe 2004; Alison 2009; Sjoberg and Peet 2011). Beyond an understanding of the gendered effects of war and how women become victimized, scholars have sought to understand gendered agency in war, showing how women navigate insecurity and seek opportunities (Jacobs, Ruth, and Marchbank 2000; Moser and Clark 2001). An important strand in the literature explores how violent conflict may involve shifting gender roles, power relationships, and shape gendered identities ( El-Bushra 2003; Cohn 2013). The literature also examines why women may join conflict. Drawing on research in Northern Uganda, Sierra Leone and Mozambique, Mazurana and McKay (2004) present a range of reasons which inspire women and girls to enter armed forces: to seek revenge, to express political opinions, to uphold religious identity, to ameliorate poverty, and/or to see protection from violence. Studies from other regions introduce the prospect of women's emancipation as a motivating factor for participating in armed conflict. Kampwirth's (2002) study on Latin American guerrilla movements found that family traditions of resistance, early networking in church, student youth groups, and revolutionary networks played a role, but so did age, as younger women without family responsibilities were more likely to join. Similarly, Alison's (2009) study in Sri Lanka proposes five reasons why women join the Liberation Tamil Tiger Eelam (LTTE) as fighters: nationalist sentiment, suffering and oppression, educational disruptions and restrictions, sexual violence, and the desire for women emancipation.

What these studies reveal is that women may join fighting forces as an escape route from a mix of (gendered) pressures, but also due to ideological and political motivations. Armed struggles may offer women the prospect of empowerment, both at the individual level and more broadly. Work to date has shown how women might gain power in armed groups, search for their voice, claim equality, renegotiate gender roles, and engage with advocacy and struggle for women's rights (Hilhorst 2001; Niner 2011; Denov and Ricard-Guay 2013). The literature has paid less attention on the role of ideology and women's motivations. This paper explores what the 
Maoist ideology of (gender) equality meant to women, and how it not only attracted them to the movement but kept them engaged as they connected it to their own personal struggles for empowerment. In the narratives of women ex-combatants, it is the Maoist discourse of gender equality in combination with the practical organization of a more equal division of labor, which allowed for transformative experiences. By zooming in on the narratives of women who joined the Maoist struggle, this paper provides ethnographical depth that allows us to show not only what this ideological commitment and empowerment meant to them, but also how they sought to carry it forward after the peace agreement which they hoped would bring lasting gender transformations. As we do this, we trace how caste, class and gender identities intersect.

\subsubsection{Integrating Intersectionality}

Crenshaw (1989) is accredited with originating the notion of intersectionality to address the experiences and struggles of women of color who fell in-between the feminist and anti-racist discourse. Since then, intersectionality has become a key concept used to analyze the multiple forms of discrimination affecting women, as well as the differences between them. In the case of Nepal, a growing body of feminist scholarship has focused on intersectionality and moved to reconsideration of differences and inequalities between women (Tamang 2009; Nightingale 2010; Ramnarain 2014). Tamang (2009, p.10) critically examines the participation of Nepalese women in different political processes including the Maoist struggle and provides a strong contribution to theorizing intersectionality in Nepal, offering an explicit exploration on how gender intersects with caste, class, religion, ethnicity, politics and geography, and argues why portraying Nepali women as a universal category is inappropriate. Furthermore, Nightingale's (2010) study in Mugu, Nepal explores how gender and caste intersected in the daily lives of Dalit and non-Dalit women and reproduced hierarchy. At the same time, an empirical study by Ramnarain (2014) points out how widows' identities intersect with gender, caste, class and age in their struggle for survival in post-conflict Nepal.

This article draws upon these frameworks on intersectionality to examine women excombatants' differentiated experiences in Maoist conflict and post-conflict Nepal. As we will show, their narratives reveal that their struggle for empowerment engages gender, caste, and multiple forms of discrimination within a broader critique of poverty and exploitation. The Maoist emphasis on gender and caste equality was experienced as liberating by women of all castes. 


\subsection{Methodology}

This paper employed ethnography approach utilizing in-depth interviews, key informant interviews and focus group discussions. The interviews were conducted by the first author, a Nepali, in the framework of Ph.D. research. Thirty-five Maoist women ex-combatants were interviewed for this study. In addition, four focus group discussions were conducted with women ex-combatants and key informant interviews with local leaders. Finding female excombatants for interviews proved very challenging. Respondents were living in Chitwan district where they had settled after completing demobilization ${ }^{13}$, but none were from Chitwan originally. At first, Maoist political leaders were contacted by drawing on earlier established networks. They provided the contact details of five former Maoist commanders, who then provided contacts of a few women ex-combatants in various districts of Nepal. Chitwan district was then selected because the women ex-combatants there seemed more willing to participate. Additionally, women were then approached through snowball sampling. Respondents interviewed originated from various districts including Gorkha, Kalikot, Rukum, Salyan, Kavre, and Sinduli. They belong to a variety of castes and ethnic groups: Tamang, Magar, Thami, Gurung, Rai, Limbu, Tharu, Dalit; two women were from high castes (Bahun and Chettri).

The field work lasted from January 2014 until February 2015 and was conducted in various episodes. Before starting the field work, two exploratory visits were made in December 2013 and January 2014. During these visits, the author introduced herself, offered her background and family information and answered participants' questions. This helped to build trust with the women.

The interviews lasted from two to three hours each and follow-up visits were made to the same women several times. The interviews were conducted entirely in Nepali and audio-recorded. Notes and photographs were taken only after getting consent from the interviewees. The main

\footnotetext{
${ }^{13}$ According to the UN (2000) demobilization: is the process of dismantling of the military units and the transition of combatants from military to civilian life. This phase also includes: i) processing individuals: combatants are settled in temporary centres (such as; cantonments, camps, or assembly areas), and are given options to transition to civilian life, and their family/community members are contacted. ii) Delivering assistance: providing combatants with support or insertion packages (i.e.; cash, compensations, basic materials, trainings, and stipends for education) to sustain them during their transition from camp to civilian life.
} 
researcher had the advantage of being Nepalese: interacting in Nepali language made the interviews more lively and in-depth, and the researcher was able to understand the local slang, which gave cultural and contextual meaning to the topic. Furthermore, sharing a context regarding history, culture, food habits, clothing, marriage, religion, and local festivals enabled the researcher to become an insider. After collection, the data was translated into English then interpreted and analyzed using Atlas ti software. To maintain confidentiality of the interviewees, all the name in the paper are pseudonyms, however, the participants' gender, caste and ethnicity are retained in the surnames.

\subsection{Maoist Ideology: The Prospect of Empowerment}

This section analyzes how women ex-combatants narrate being attracted to the Maoist struggle. Ideology and aspirations of empowerment played a prominent role in their narratives. In the Maoist discourse, the people's war is clearly framed as an avenue for women's emancipation. In her article "Women Participation in the People's War," Parvati (2003) a high-level female leader, argues that the Maoist revolution empowered rural Nepali women to dismantle feudal structures. She illustrates this argument with an example from Rolpa district, where a women guerrilla squad removed a feudal tyrant who had abused women sexually. Other scholars likewise confirm the emphasis in Maoist ideology on the emancipation of women and on ending gender discrimination (Manchanda 2004; Sharma and Prasain 2004). In addition, as mentioned, the 40-points demand document released in 1990 is considered particularly vital to understanding Maoist ideology (Karki and Seddon 2003). In its points 19, 20 and 21, the position of women is addressed, along with the need to transform state and customary laws to redress gender inequality at all levels. In 2002, in recognition of their female constituency, the Maoists introduced the so-called "Prachanda Path" creating a women's department in the Central Committee (Manchanda 2004, p.248).

The fieldwork in Chitwan district in 2014 and 2015 gave us an understanding of how excombatant women had experienced the Maoist position on gender equality in discourse and in practice. Most of the women ex-combatants interviewed had grown up in rural villages in Nepal and offered their individual stories, illustrating the appeal of the Maoist ideology. Shanti Tharu explains: 
I am a Tharu woman, I worked at jamindar (landlord) house, had never been to school could not imagine my life beyond working as maid... One day I attended a Maoist cultural program; there was a play focused on caste discrimination ...I could situate my everyday reality in that play...Later I attended some Maoist meetings with my friends, our comrades; in the meetings our 40-point demand was discussed which particularly explained mahila ko adhikar (women's rights)., I felt the Maoists gave ijjat (respect) also to lower caste woman like me ...unlike jamindar (the landlord) who always verbally abused me and my family. When I was 17 years, I became an active Maoist member ... They appointed me as area secretary, and later I converted to be a Maoist combatant. (May 2014).

Other accounts show how the Maoist message resonated with experiences of caste discrimination. Manju Bishwokarma emphasized the suffering she experienced as a Dalit woman:

I am a Dalit woman...I remember when I was a child, one day, I unknowingly touched a jug of water at a tulojati's (upper caste) house. My parents were insulted for not teaching me and my father punished me. Born as a Dalit's daughter, my father never sent me to school like my brothers. I struggled with my own identity, why I am untouchable. One day I went to the Maoist program in my area and I experienced that I was treated equally as other caste people, so I was inspired to join to end gender, caste and social inequality. The Maoists made me wardvice-president. (September 2014).

The above descriptions demonstrate how women understood the Maoist ideological proposal in terms of women's empowerment and how this was particularly relevant to women from lower castes. Padma Thapa's (another participant) story also illustrates this. She told us that when she was only 18 years of age, she saw violence and abuse against poor people taking place in her village. Security officials did not protect the local people, and the media never reported it, as it would mean acting against the interests of the rural elite. She worked at a landlord's house to fulfil her father's debt and was accused of not performing her duties as a girl (fetching water early, cooking, cleaning). The Maoist party came to the region in 1997, and as Padma explains: "I attended Maoist rallies, door to door events, and found that hamro awaaj (our voice) is the Maoist voice, thus I decided to become a Maoist combatant.” (August 2014).

In another story, Binita Magar stated why the Maoist ideology appealed to her: 
I was married before joining the Maoists. Me, my brother and his wife were suspected of being Maoists in the early 1990's when the Maoist guerrilla just began to form. The wife of my brother was killed in front of my old parents in the village by the government army. There was no justice for poor people like us. My father in-law motivated me and my husband to join and get justice for our loved ones. (March 2014).

The explanations show how women felt empowered by the Maoist ideology as they were able to raise their voice against the suffering they were witnessing and resist the inequalities and discrimination they and their families were experiencing. In addition, these narratives also demonstrate how women's lives emerge at the intersection of gender, caste and other identities.

In the case of Shanti Tharu everyday suffering was reproduced through an intersection of gender, caste, age and position in the family. For Manju Bishwokarma, her caste (Dalit) intersected with her gender, culminating with her daily oppression of untouchability. Likewise, Padma Thapa's case reveals how her gender intersects with her age, and hence she is victimized to perform as a domestic maid, preventing her from experiencing other girlhood opportunities. Similarly, Binita Magar's story reflects how her gender intersects with her position as daughterin-law, which shaped her political decision to join the Maoist.

Based on the conversations with women ex-combatants, we conclude that the majority of them made a conscious choice to join the Maoist struggle and either were attracted to the Maoist ideological message or became familiar with it once they had joined. Some women joined the movement due to the family's loyalty to the Maoist insurgency, which later turned into a personal commitment to fight against gender, caste, and other forms of oppression. Such transformation occurred as women experienced the Maoist ideology in their daily lives; as they came to occupy new types of gender roles and caste hierarchies were disrupted. The Maoist message of ending discrimination reinforced their personal aspirations to achieve equality.

The women first became familiar with the Maoist discourse through cultural programs, door to door visits, meetings, and rallies organized by the Maoists in the villages. Once they had joined the Maoists, women were offered positions equal to men in their local areas; for example, Manju Biswokarma was appointed as vice-president and Shanti Tharu as secretary. Women felt the Maoists displayed respect for women as well as other marginalized groups and this fueled their aspiration and empowerment. The Maoists challenged caste and patriarchal 
systems by offering equal treatment to Dalit, providing opportunities to women and encouraging them to fight for their rights. This is what made women believe that the Maoists were serious about achieving gender equality.

In the next section we investigate what motivated women's continued commitment to the Maoist cause.

\subsection{Women Ex-Combatants' Experiences in the Maoist Conflict}

This section, we present the stories of how women ex-combatants experienced the Maoist insurgency and how an experience of empowerment sustained their continued commitment. The way the Maoists were organized in practice crosscut traditional role divisions and stood in great contrast to the life women had been used to. Women highlighted this change as empowering. The following quotes serve to illustrate women's experiences, across castes.

Gita Lamichane, an upper caste woman, found she could take up leadership roles on an equal footing with men:

I was a company commander. Before I could not imagine that I would perform such roles. It happened thanks to the support and encouragement of my Maoist peers. Especially in the morning training speech our leaders (both women and men) touched upon topics that were empowering: rights, equality, health, local and global politics and many more. I organized workshops, worked at the communications department, the health department. I carried guns, led attacks, I performed tasks equal to the men. In the village I was prevented from anything outside home due to my Bahun (upper caste) culture and tradition. I never went to school whereas my bothers did, and my parents said girls must maintain shyness. (June 2014).

A Dalit woman, Janaki Biswokarma, provides a similar story:

I was a very shy girl, but after becoming a combatant I led the guerrilla trainings and gave them command. I made fast promotion and got special treatment from our leaders, very different to what I went through in the village. By yudama hidaa (going to war) I could feel that I am equal to all other castes. I realized how before there had been caste and gender discrimination, now my life became free of the everyday oppression [one experiences when] surviving as aachut jat (untouchable caste). (January 2015). 
Similarly, Bandana Magar explained:

I performed a medical health technician job in the Maoist insurgency. I was trained for this job in the Maoist war...I had dropped out of school at the age of 13 due to my father's poor financial condition. After becoming a Maoist, I learned that women could also perform men's work, decent jobs valued in society. I conducted minor operations: removing bullets, stitching the wounds, and a lot of 'medical emergency stuff.' The Maoist movement offered opportunities to me that would never have been possible otherwise. (August 2014).

This picture of women taking up jobs previously only associated with men was corroborated in interviews with male ex-combatants, who were husbands of the women ex-combatants. They shared in the interviews that in some cases their wives had held senior positions to them and described them as strong and bold. They said that many times women performed better in conducting attacks and generating reliable information while spying.

The tasks traditionally seen as women's work were shared between men and women, as evidenced in the following quote of another woman ex-combatant, Sapana Tamang:

In the $y u d h a$ (war) I worked together with Maoist men. The daily routine was made up of both public (war) related tasks and private tasks such as cooking, cleaning, fetching water, washing dishes. Men also cooked food washed dishes and cloths and did other feminine duties. I saw with my own eyes that men can also perform household duties like women. In the war I found male colleagues were very disciplined, they treated women with respect. This was striking as back in village men never touched such feminine things (cooking, cleaning), whatever happened. (July 2014).

Women's narrations reveal that they experienced the Maoist commitment to women's issues as real on the ground. Our participants reported feeling empowered as they were assigned public roles equal to and sometimes above their male peers, and in some cases, placed in powerful positions: managing military tasks, and taking charge of various attacks and departments. They reported being in a better position than before the conflict, more able to express their feelings, make their own decisions and live with selfconfidence. Women found these new roles challenging but were assigned responsibilities equal to men, were encouraged to take up new positions and, in some cases even make 
promotion. These accounts shatter the general assumptions about women's subordinate roles in violent movements and liberation struggle.

The interviews also demonstrate that the experience of empowerment crossed caste lines. Both upper and lower caste women reported escaping the previous limitations of the patriarchal structure and contrast their lives before and after joining the insurgency. Gita Lamichane, a respondent from the upper-caste (Bahun) had faced cultural constraints before the war which restricted her to the home; particularly in Bahun families, girls have less freedom than other castes (Ramnarain 2014), including Gita's argument reflects that even woman of 'upper caste' encounters similar or even worse discrimination. The lower caste, Dalit woman, Janaki Biswokarma, felt empowered when she saw that unlike normal practice in her village, work was not divided according to caste and equal treatment was given to woman of all caste.

Our findings on the case of Nepalese women ex-combatants reflect parallels with the LTTE women fighters in Sri-Lanka. As Alison (2009) and Azmi (2015) found, women who had joined the LTTE challenged traditional norms and had the chance to perform non-traditional gender roles such as climbing trees, riding motor bikes, and participating in guerrilla trainings. These experiences of women fighters in Nepal and Sri Lanka seem to contrast with findings for cases in Africa where scholars have mostly found women to take up subordinate roles in armed groups, in line with a traditional gender role division.

McKay (2004) ${ }^{14}$ observed that girl fighters were subordinated to men, being forced to load guns or be the wives of commanders, lower rank fighters who loot, first-aid workers, spies and porters. This contrast might be related to the fact that significant numbers of girls and women were forcibly recruited and abducted (McKay and Mazurana 2004), rather than ideologically motivated as in Nepal and Sri Lanka.

\footnotetext{
${ }^{14}$ McKay's work (2004, p.21-22) in Africa, Sierra Leone and Northern Uganda found that girl fighters performed multiple roles. Some were forced to be wives of the commanders, a few were trained to load the guns, first-aid workers, spies, porters, or messengers. Likewise, in Mozambique, girls were mostly conscripted or kidnapped, and they performed duties such as domestic servants, medics, and, the wives of captor-husbands.
} 


\subsection{Women Ex-Combatants' Experiences in The Aftermath of the Maoist War}

After the signing of the peace agreement in 2006, female ex-combatants had hoped to carry the Maoist gender equality agenda forward into the post-war period. Our interviews show, however, that they experienced the peace process as a big step backwards: in their private lives, they lost the sense of empowerment they had enjoyed during the insurgency as achievements of gender equality dissipated and further, they were left politically disenchanted as they felt the Maoist commitment to ending gender discrimination waned. Before addressing this, we start with a brief overview of developments at the national level.

Things seemed initially promising. After 2006, and the peace process, gender equality was high on the agenda in Nepal. Local, national and international organizations started to integrate gender and women's issues into their policies and programs (IPTI 2016). This included reserving political positions for female candidates, creating a gender task force, allowing paid maternity leave, and equal pay. There were some achievements: Nepalese women came to occupy high-level executive positions and are heading top national level non-government organizations (NGOs) and as such are involved in peace building and the development process.

Women's rights became an important issue at the national level, at least in discourse. Nepal made considerable steps forward on the issue of women's rights and political participation. Nepal's New Constitution 2015 reserved 33 percent of parliamentary seats for women (Upreti and Kolås 2016). In the first Constituent Assembly of 2008, women made up 33 percent; the Maoists as the largest party had 74 women members out of the total 197 women members (Ramnarain 2014). In contrast, in the 1991 elections only 7 women had been elected out of 205 legislatives representatives (Yami 2007). Women also participate in peacebuilding through organizations such as the National Women Commission Nepal, Women's Alliance for Peace, Justice and Democracy. Local women's organizations, including NGOs, are also working for the inclusion of women (Upreti and Kolås 2016).

Despite these advances, there have been serious setbacks. In the Constitutional Assembly (CA) election in 2017 only six female candidates were elected to the house of representation $(\mathrm{HoR})^{15}$

\footnotetext{
${ }^{15}$ The House of Representation (HoR) is comprised of 275 members, of whom 165 are elected through firstpast-the-post (FPTP) and 110 through closed list proportional representation (PR). The constitution mandates at least 33 per cent of female candidacy under FTTP and the provision of PR system is to be enacted only when
} 
out of 165 members; a significant decline from the first CA elections in 2008 when a total of 30 women were elected to the HoR (Shrestha 2017). Furthermore, the recent Constitution of Nepal (2015) is a step backwards from the Interim Constitution of 2007 in terms of citizenship rights for women. For example, in the current provision, Nepalese women and their children need to be born in Nepal to obtain citizenship by descent, whereas this is not applied to the children of Nepali men (see more Constitution of Nepal 2015; Article 10,p.11). Furthermore, while Article 38.6 of the Constitution mentions that "both the spouses shall have equal rights in property and family affairs," considerable challenges remain to fully implement such provisions on the ground.

Since 2008, the Maoist party has become one of the largest and most powerful political parties in Nepal, and two prime ministers from this party have served the nation. The Maoist postconflict priority shifted to addressing macro conditions, such as restructuring the state and forming a new government after the 2017 constitution assembly elections. The Maoist ideology on women's empowerment has now become less of a priority. It is true that some Maoist women now hold leadership positions at the level of Constitution Assembly, in national and local politics, but at the grassroots level, Maoist women ex-combatants have encountered an extreme transition back into the highly patriarchal social structures that they had imagined to be changed (K.C. 2011; K.C., Van der Haar and Hilhorst 2017).

The stories of women ex-combatants show their disenchantment with the hardships of everyday life, and at the same time their continued ideological drive to end gender discrimination.

The story of Bimala Thami (a former Maoist company commander) illustrates this:

I see that thanks to the Maoist movement women empowerment is taking place, and women are given various positions in the country...but what worries me is that such gender equality is not happening equally. Mostly, only women from well-off families, educated, and with strong political background are occupying these opportunities, while women like me are suffering everyday to meet our basic needs, I am still fighting for women's equal rights. I am

FTTP fails to bring about a third of the representation. However, political parties are utilizing the PR system as the only avenue to fulfil the one-third representation of female candidates in federal parliament (The Kathmandu Post, 2017, citied in Adhikari, 2018,p.1). 
a member of the former people's liberation Army (PLA) Mahila prathisthan (women's organization), here we promote women's voices through conducting local level programs and rallies to give political pressure to the government...because if we remain silent our voices can be easily erased, and we will be forgotten (May 2014).

Challenges reported by women ex-combatants include difficulties in finding work, fulfilling basic needs, and being blamed for war violence. In different ways, ex-combatant women came to realize that the patriarchal structure has remained unchanged. Sunita Rai narrates:

I came to know about a painter job vacancy from my friends. I was interested to do painting, I also had some experience. When I reached the employer, he denied and made fun of me saying "you Maoist woman, go play with guns, why are you here? If you, woman, will do this painting job it is never going to finish, I don't want to lose my business" It is hard to find a job as an uneducated woman like me. Other Maoist women are facing the same stigma when looking for a job. This is a serious issue which prevents women from entering the public sphere. I will not give up but fight till the end to protect women's voices (August 2014).

Sarita Chettri; belonging to a non-Maoist Chettri (upper caste) family, faced challenges related to traditional patriarchal mindsets. Her family rejected her because she had joined the Maoists and had disobeyed the family rules. Furthermore, her parents disapprove of her inter-caste marriage to a Magar man. She has two small children and her husband works as a laborer on a dairy farm run by Maoist friends. She completely relies on her war peers for any help. (Interviewed in December 2014). Sarita's wartime inter-caste marriage to a Magar testifies to her empowerment, but in post-war Nepal her inter-caste marriage meets rejection.

One study argues that there was some progress on women's issues in post-war Nepal thanks to the efforts of the Maoist party. Yadav (2016) studied female Maoist parliamentarians who had been Maoist cadres, and claims that without the Maoist movement these women could never have made it to parliament. Here close vigilance is required. As suggested by Tamang (2009) we need to understand which groups of women have benefited from quotas for gender, caste and ethnicity, and why other groups, like other women ex-combatants, are neglected.

Ex-combatant women remain committed to the idea of gender equality and are frustrated both with the constraints they face in their daily lives and with what they see as negligence of women's issues by the Maoist leadership. Women are dedicated to their ideological drive for 
empowerment and bringing overall gender equality to the period after the war. Facing difficulties in finding jobs and new forms of war-related stigmatization they have started to fight back through various protests, targeting the Maoist party as well as the government. In September 2014, Maoist followers arranged a protest against their own party in Kathmandu, with large numbers of Maoists, including women ex-combatants, participating. One of the women ex-combatants who participated in the study, Renu Tamang, also took part. She explained that the protest raised issues about jobs, skills programs, health and credit facilities, and educational issues. But these issues never became a priority and disappeared from the Maoist party's agenda. She added: "I just wasted my savings paying to bus and hotel fare". (July 2014).

The return to civilian life has been a challenging experience for women ex-combatants in Nepal. One of the reasons is that Nepal's post-conflict reintegration ${ }^{16}$ process has remained highly male-centric; the absence of a 'gender framework' in the reintegration ${ }^{17}$ programming failed to legitimize or support women's transformed roles, or to include women's voices.

As a result, post-conflict reintegration policies have offered few concrete options to women (Goswami 2015).

The story of Asha Gurung (a Maoist ex-company commander) illustrates how she felt excluded from the reintegration process:

I was interested to go for the option of entering the Nepalese army, but I could not pass the entry exam because I do not have education. I have never been to school. This is the failure of our Maoist leadership: they did not negotiate our education level, though they knew many women ex-combatants lack education. I totally felt excluded from reintegration process. (December 2017).

\footnotetext{
${ }^{16}$ Reintegration programming offered three options for ex-combatants i) integration into the Nepal Army, ii) voluntary retirement with a cash compensation or iii) a rehabilitation package.

${ }^{17}$ To demilitarize; disarmament, demobilization, reintegration (DDR) approach is deployed. After conclusion of the disarmament, demobilization, the reintegration stage is crucial component of DDR because ex-combatants acquire civilian status or return home. It is essentially a social and economic process, primarily taking place in communities/family at the local level.
} 
Only a total of 104 women ex-combatants succeeded in gaining a position in the Nepal army out of 3,846 verified ${ }^{18}$ women ex-combatants (Bhandari 2015). These findings resonate with the patterns of exclusion of women from reintegration processes elsewhere, their specific needs and interests not being taken into consideration (McKay and Mazurana 2004).

Furthermore, the female ex-combatants hardly seem to benefit from the numerous gender programs developed in post-conflict Nepal. There are programs on peacebuilding, women's empowerment, income generation, and post-conflict reconstruction (K.C., Van Der Haar and Hilhorst 2017), including in and around Chitwan district where this study took place. However, these programs largely focus on non-combatant women. To our surprise, only one of the women ex-combatants interviewed received the opportunity to participate in a kitchen garden training, some years ago.

This study shows although the Maoist movement created opportunities for women and promoted the idea of equality, after the war women felt abandoned. Gender equality endures only at the level of rhetoric and fails to benefit women at the grassroots. Ex-combatants felt women's issues were ignored and excluded from the peacebuilding process. Though women experienced transformations such as inter-caste marriages, making their own decisions, and voicing their rights in the aftermath of war, they faced setbacks in their private lives. Women combatants felt stigmatized in the post-conflict setting, more strongly than their male peers. All of the women combatants interviewed were married to Maoist men ex-combatants. They felt empowerment through their marriages, forming life alliances with men who support changed gender roles and hence are more appropriate partners for them. In contrast, their unmarried female ex-combatant friends are now faced with difficulties finding suitable marriage partners, as they are not considered suitable wives or proper women. Unmarried men ex-combatants do not have such problems.

Our results demonstrate that the empowerment experienced by women ex-combatants remains ambivalent. Patriarchal structures continued intact and, in some ways, even strengthened. Women's war related roles were devalued in the post-war context, there was a lack of commitment from the Maoist party to issues of gender equality and in particular to the situation of women ex-combatants, and a gender framework for reintegration programming was lacking.

\footnotetext{
${ }^{18}$ Fulfilling the criteria of Nepal Government to qualify as Maoist combatant.
} 
Pre-war problems such as lack of access to education, skill training, property, and power resurfaced in the period after the war. To resume 'normalcy' women were forced to adjust to the patriarchal structures they had hoped to escape.

This is similar to what has been found, in Sri Lanka, where the evidence suggests that LTTE women who performed non-traditional roles and gained empowerment during the armed conflict, experienced a backlash in peace time due to lack of education and training, the unwillingness of society to accept women performing non-traditional roles, incomplete reintegration programs, and a patriarchal system that positions women as submissive (Rajasingham-Senanayake 2004; Azmi 2015). What has been suggested by Hilhorst, Haar and Weijs $(2017$, p.4) in a more general sense seems relevant also to gender transformation: the windows of opportunity opened by a peace process "may be experienced [by different people] in very different ways and to varying degrees, or indeed not be experienced at all."

\subsection{Conclusions}

The Maoists in Nepal developed an ideology of gender equality as part of their broader struggle against oppression. Women's rights have also been an important theme in the post-conflict peace-building process, and some noticeable achievements have been made in regard to women's issues in general. Women felt empowered through the Maoist ideology as they were exposed to non-traditional gender roles; experienced an equal division of labor, power and positions; and enjoyed equal treatment regardless of identity, caste, gender, ethnicity, positions, and class. However, in the post-conflict setting, the Maoist ideological commitment to gender equality is still far from being a practiced reality. What Enloe $(2004,226)$ has observed on post-conflict settings in general seems also to hold true in Nepal: “...masculinized exclusion is made all the more intense... as a result, women's well-being in the reconstructed post conflict society will still be left on the proverbial back burner."

The women we interviewed identified themselves as being 'agents of change' who fought the war to transform women's lives in Nepal. After the war, these women were politically aware, made conscious decisions about their marriages and children's education, and could well identify their everyday gender needs. At the same time, women face multiple challenges in their everyday lives in post-war Nepal due to the male-centric reintegration process, the decline of the Maoist ideological commitment to women ex-combatant's issues, the masculine job 
market, pervasive patriarchal mindsets, and homogenizing women ex-combatants under one category. Incorporating an intersectional approach reveals the differences between women excombatants' lived experiences.

The development of gender equality in post-conflict Nepal seems very paradoxical. To some extent, the Maoist struggle delivered an avenue to realize the gender ideology for which they fought so proudly, but on the other hand, some of the most fervent fighters for women's rights are marginalized from the peace process. The post-conflict setting reproduces the discrimination in a different form for these women who were fighting against it. 


\subsection{References}

Adhikari, Monalisa. 2018. "Ending the Political Transition? Analysing the Nepal Elections from an Inclusive Prespective." Political Settlement Reaserch Programme (PRSP). http://www.politicalsettlements.org/2018/01/18/ending-the-political-transitionanalysing-the-nepal-elections-from-an-inclusion-perspective/.

Alison, M. H. (2009). Women and political violence : female combatants in ethno-national conflict (First). London: Routledge.

Arostegui, J. (2013). Gender, conflict, and peace-building: how conflict can catalyse positive change for women. Gender \& Development, 21(January 2015), 533-549. https://doi.org/10.1080/13552074.2013.846624

Asian Development Bank. (1999). Women In Nepal.

Azmi, F. (2015). IWantMyWings Back to Fly in a New Sky: Stories of Female Ex-LTTE Combatants in Post-War Sri Lanka Fazeeha. In S. Shekhawat (Ed.), Female Combatants in Conflict and Peace: Challenging Gender in Violence and Post-Conflict Reintegration (pp. 200-2015). London: Palgrave Macmillan.

Bhandari, C. (2015). The Reintegration of Maoist Ex-Combatants in Nepal. Economic \& Political Weekly, L(9), 63-68.

Cockburn, C., \& Cockburn, C. (2013). War and security, women and gender : an overview of the issues War and security, women and gender : an overview of the issues. Gender \& Development, 21(3), 433-452. https://doi.org/10.1080/13552074.2013.846632

Cohn, C. (2013). Women \&Wars (First). Cambridge: Polity Press.

Crenshaw, K. (1989). Demarginalizing the intersection of race and sex: A black feminist critique of antidiscrimination doctrine, feminist theory and antiracist politics. University of Chicago Legal Forum, 139-167.

Dahal,Swechchha.2015."ChallengingTheBoundariesTheNarrativesoftheFemaleExCombatan ts." In Female Combatants in Conflict and Peace: Challenging Gender in Violence and Post-Conflict Reintegration, edited by Seema Shekhawat, 185-199. London: Palgrave Macmillan.

Constitution of Nepal. 2015. The Government of Nepal. Kathmandu: Ministry of Law, Justice and Parliament Affairs.

Denov, M., \& Ricard-Guay, A. (2013). Girl soldiers: towards a gendered understanding of wartime recruitment, participation, and demobilisation. Gender \& Development, 21(3), 473-488. https://doi.org/10.1080/13552074.2013.846605 
Dhungana, R. K. (2014). Nepali Hindu Women's Thorny Path to Liberation Raj, School of Education, Kathmandu University, Lalitpur, Nepal. Journal of Education and Research, 4 (1), 39-57. https://doi.org/: http://dx.doi.org/10.3126/jer.v4i1.10013

El-Bushra, J. (2003). Fused in combat: Gender relations and armed conflict. Development in Practice, 13(2-3), 252-265. https://doi.org/10.1080/09614520302941

Enloe, C. (2004). The Curious Feminist Searching for Women in a New Age of Empire.

Gautam, S., Banskota, A., \& Manchanda, R. (2001). Where There Are No Men Women In The Maoist Insurgency in Nepal. In D. Thapa (Ed.), Understanding the Maoist Movement in Nepal (First, pp. 93-124). Kathmandu.

Goswami, R. (2015). UNSCR 1325 and Female Ex-Combatants-Case Study of the Moiast Women of Nepal. New York.

Hilhorst, D. (2001). The Power of Discourse: NGOs, Gender and National Democratic Politics. Asian Studies, 37(1), 1-35.

Hilhorst, D., Van Der Haar, G.and Weijs, B. (2017). Facing Fragilities: The Socially Embedded Nature of Socio-Economic Recovery, in People, Aid and Institutions in Socio-Economic Recovery. Routledge

Inclusive Peace \& Transition Initiative. (2016). Women in Peace and Transition Processes Nepal (2008-2012). Geneva.

Jacobs, S., Ruth, J., \& Marchbank, J. (2000). States of Conflict: Gender, Violence and Resistance. (S. Jacobs, J. Ruth, \& J. Marchbank, Eds.). New York: Zen Books.

Kampwirth, K. (2002). Women and Guerilla Movements: Nicaragua, El Salvador, Chiapas, Cuba (First). University Park, Penn: Penn State University.

Karki, A., \& Seddon, D. (2003). The People's War in Nepal Left Perspectives. Adroit Publishers.

K.C., L. (2011). Securing Livelihoods: Reintegration of Former Maoist Mother Combatants with Children in Post Conflict Nepal. Wageningen University, The Netherlands.

K.C., L., Van Der Haar, G., \& Hilhorst, D. (2017). Changing Gender Role: Women's Livelihoods, Conflict and Post-conflict Security in Nepal. Journal of Asian Security and International Affairs, 4(2), 175-195. https://doi.org/10.1177/2347797017710743

Lawoti, M., \& Pahari, A. K. (2009). The Maoist INsurgency in Nepal Revolution in the Twenty-First Century. Routledge.

Manchanda, R. (2004). Maoist Insurgency in Nepal: Radicalizing Gendered Narratives. Cultural Dynamics, 16, 237-258. https://doi.org/10.1177/0921374004047750

McKay, S. (2004). Reconstructing fragile lives: Girls' social reintegration in northern 
Uganda and Sierra Leone. Gender and Development.

https://doi.org/10.1080/13552070412331332280

Mckay, S., \& Mazurana, D. (2004). Where are the girls? Girls in fighting forces in Northern Uganda, Sierra Leone, and Mozambique. Their lives before and after war. Gender Studies Database.

Moser, C. O. N., \& Clark, F. C. (2001). Victims, Perpetrators or Actors? Gender, Armed Conflict and Politial Violence. ZED Books.

Nightingale, A. J. (2010). Geoforum Bounding difference : Intersectionality and the material production of gender, caste , class and environment in Nepal. Geoforum, 42(2), 153162. https://doi.org/10.1016/j.geoforum.2010.03.004

Niner, S. (2011). Hakat Klot, Narrow Steps. International Feminist Journal of Politics, 13(3), 413-435. https://doi.org/10.1080/14616742.2011.587371

Parvati, C. (2003). Women's Participation in the People's War. In A. Karki \& D. Seddon (Eds.), The People's War in Nepal Left Perspectives (p. 495). Adroit Publishers.

Pettigrew, J., \& Shneiderman, S. (2004). Women and the Maobadi: Ideology and Agency in Nepal's Maoist Movement. Himal Southasian, 17(January), 19-29.

Rajasingham-Senanayake, D. (2004). Between Reality and Representation: Women's Agency in War and Post-Conflict Sri Lanka. Cultural Dynamics, 16(2-3), 141-168. https://doi.org/10.1177/0921374004047741

Ramnarain, S. (2014). Universalized categories, dissonant realities: gendering postconflict reconstruction in Nepal. Gender, Place \& Culture, 22(9), 1305-1322. https://doi.org/10.1080/0966369X.2014.958062

Regmi, S. (2007). Nepali Women and Their Struggles over Water during Pregnancy. International Feminist Journal of Politics, 9(4), 522-523. https://doi.org/Regmi, Sabrina. 2007. "Nepali Women and Their Struggles over Water during Pregnancy." International Feminist Journal of Politics, no. December: 522-23.

Ruwanpura, K. N., \& Humphries, J. (2004). Mundane heroines : Conflict, Ethnicity, Gender , and Female Headship in Eastern Sri Lanka, 10(2), 173-2015. https://doi.org/10.1080/1354570042000217766

Seddon, D. (2003). Maoist Staement and Documents; The Maoists' 40-Point Demands. In A. Karki \& D. Seddon (Eds.), The People's War in Nepal Left Perspectives (pp. 183-187). Sharma, M., \& Prasain, D. (2004). Gendered Dimensions of the People's War: Some Reflections on the Experiences of Rural Women. In M. Hutt (Ed.), Himalayan People's War: Nepal's Maoist Rebellion (pp. 152-164). Indiana University Press. 
Shrestha, P. M. (2017, November 7). Seats up but claimants fewer than in CA vote. Ekantipur, p. 1. Kathmandu.

Sjoberg, L., \& Peet, J. (2011). A(nother) Dark Side of the Protection Racket. International Feminist Journal of Politics, 13(2), 163-182. https://doi.org/10.1080/14616742.2011.560751

Tamang, S. (2009). 91 the politics of conflict and difference or the difference of conflict in politics : the women's movement in Nepal. Feminist Review, 61-80. https://doi.org/0141-7789/09

Thapa, M. (2003). “Girls in Nepal's Maoist War.” Himal South Asian.

Upreti, B. R., \& Kolås, Å. (2016). Women in Nepal's Transition. PRIO Policy Brief, (11), 2016

Yadav, P. (2016). Social Transformation in Post-conflict Nepal. Taylor and Francis:ProQuest Ebook Central.

Yami, H. (2007). People's War and Women's Liberation in Nepal. Janadhwani Publication.

Yami, H. (2010, March). Women's role in the Nepalese movement: Making a people's constitution. Monthly Review Foundation. 


\section{Chapter 5: Everyday Realities of Reintegration: Experiences of Maoist 'Verified' Women Ex- Combatants in the Aftermath of War in Nepal}

This chapter has been accepted for publication (with revisions) at Conflict, Security \& Development as:

K.C., Luna. (2018). 'Everyday Realities of Reintegration: Experiences of Maoist 'Verified' Women Ex-Combatants in the Aftermath of War in Nepal. 


\begin{abstract}
Global studies around women's experiences in the disarmament, demobilisation and reintegration (DDR) process have explored its implications on women in the post-war period. Scholars have already pointed out that ex-combatants in Nepal are facing difficulties in the reintegration period. This paper examines in particular the consequences of the DDR process for so-called Maoist 'verified' women ex-combatants, 'verified' meaning those who were formally acknowledged as a former Maoist combatant, and they participated in the entire DDR process. The paper asks how these women experienced the DDR process, especially the reintegration phase, and how it shaped their post-conflict options. The paper first problematizes the idea of a 'return to normalcy' and, second, shows how female ex-combatants suffered multiple forms of marginalisation as they sought to give new shape to their lives. I argue that this is in part due to the lack of a gender approach in the DDR policy in Nepal and the failure to take into account the voices of women ex-combatants.
\end{abstract}

Keywords: Disarmament, Demobilisation and Reintegration (DDR), Verified Women ExCombatant, Gender and Post-Conflict, Maoist Armed Conflict. 


\subsection{Introduction}

A decade of armed conflict in Nepal concluded in November 2006 with the signing of the comprehensive peace accord (CPA) between the Government of Nepal and the Maoist party. Disarmament, demobilisation and reintegration (DDR) were central to the CPA and aimed to transform Maoist combatants to citizens (Martin 2012; Subedi 2014b). This paper focuses on how female ex-combatants experienced the DDR process, zooming in particular on the reintegration.

Women combatants were heavily involved during the decade of Maoist armed conflict in Nepal. Of the total Maoist combatants, between 30-40 percent were women (Sharma and Prasain 2004), yet little attention has been paid to how Maoist women ex-combatants are coping in the aftermath of war under expectations that they 'return to normal life'. The paper examines the consequences of the DDR process for so-called 'verified' female ex-combatants, 'verified' meaning those who were formally acknowledged as former combatants. These women experienced the entire DDR process. The paper examines how they experienced this process and how it shaped their post-conflict options, with a focus on reintegration. The paper first problematizes the very idea of a 'return to normalcy' and, second, shows how female excombatants suffered multiple forms of exclusions as they sought to give new shape to their lives. I argue that this is in part due to the lack of a gender approach in the DDR policy in Nepal and the failure to take into account the voices of women ex-combatants.

A significant body of comparative literature on gender and DDR has shown that even where gender roles became more fluid during war times, and male and female combatants fulfilled similar roles, the DDR process tends to be gender-exclusive and ignore (or overlook) that women and girls combatants encounter special challenges (Enloe 2004; Denov and RicardGuay 2013; Mazurana 2013). More attention is now being paid to the centrality of female combatant roles in armed conflict and their participation in the DDR process (Cockburn 2001; MacKenzie 2009; Shekhawat 2015). In the same manner, feminist writers have raised serious concerns about reintegration programming lacking gender frameworks that would address women combatants' needs in particular (McKay and Mazurana 2004; McKay 2004). Earlier studies, mostly about Africa, have shown that women and girls are often excluded from the DDR processes because their roles in the armed conflict are seen as auxiliary (MacKenzie 2009; Mazurana and Cole 2013) and they are not recognised as 'fighters'. In the case of Nepal, 
as this paper will show, this exclusion does not happen in the disarmament phase but later, during reintegration.

Nepal's peace process and the DDR have been studied extensively, with a focus on factors heading from war to peace (Gautam 2009; Thapa and Sharma 2009; Pandey 2009; Thomas 2010). Much work to date highlights 'disqualified' combatant issues, i.e. those ex-combatants who failed to obtain formal recognition as such. This group was discharged immediately, in 2007, much earlier than the 'verified' combatants, who were completely demobilised only in 2012. At the time, there was considerable media attention on the disqualified combatants as they protested over their situation, giving rise to concern from scholars and development agencies (Subedi 2014c; 2014a). The rehabilitation of disqualified ex-combatants became strongly politicised and this affected their reintegration process (Subedi 2014c; 2014a). The Maoist party rejected a proposal from the government and the UN to collect baseline information of disqualified ex-combatants on their existing skills, educational capacity and interests, suggesting that any economic rehabilitation training was not based on real needs and failed to meet the demands of this group. This, in turn, resulted in an extreme job crisis for disqualified combatants. However, it is important to note that these studies were based on narratives of male ex-combatants (Subedi 2014c; 2014a, Bhandari 2015).

At the same time, studies about disqualified female ex-combatants highlighted the special challenges they faced — stigmatisation for returning empty handed and rejection from becoming suitable wives and mothers (Colekessian 2009; KC 2011; Bhandari 2015; Dahal 2015). This paper contributes to the literature on gender and the DDR by zooming in on the reintegration experiences of Maoist verified women ex-combatants in Nepal, who took part in the entire official DDR process. The paper is based on the narratives of Maoist verified women ex-combatants.

\subsection{Understanding Disarmament, Demobilisation and Reintegration (DDR) from a Gender Perspective}

Disarmament, demobilisations and reintegration (DDR) is considered a crucial process for long-term peace building (Knight and Özerdem 2004). In most cases, the United Nations assist with the disarmament, demobilisation and reintegration (DDR) programs (Humphreys et al. 2005). Disarmament and demobilisation, the first two components of DDR, take place before 
the reintegration phase and create the security and trust necessary for implementing peace agreements (Knight and Ozerdem 2004; Humphreys et al. 2005). After demobilisation is reintegration of the combatants, which is the most challenging period because combatants transition from combatant to non-combatant roles and likely encounter challenges around rebuilding livelihoods, searching for jobs, rebuilding trust and re-establishing family, networks and relationships (Knight and Ozerdem, 2004; Muggah 2005; Podder 2012). At the same time, this period is "crowded with gender decisions" (Enloe 1993, p.261) that men and women face differently (Mckay 2013).

Most official DDR policies assume that after the conflict ends and reintegration programs are delivered, security and normality are likely to resume and ex-combatants are expected to perform normalcy (Muggah 2005; Hauge 2008; Poddar 2012). However, such conventional practices are largely criticised for not taking into account ex-combatants' post-war transition challenges (Muggah 2005; Özerdem 2012; Podder 2012). One way of looking at the success of DDR is in terms of strict security considerations: numbers of ex-combatants demobilised, weapons reduced and destroyed, and post-monitoring of the weapons (Muggah 2005; Poddar 2012; Phayal et al. 2015; Knight and Özerdem, 2004; Özerdem 2002). Another category of DDR study suggests family and community can play constructive roles in resettling the combatants after their return because the combatant and his/her relationships are rooted in prewar conditions (Özerdem and Podder 2011; Podder 2012). Other scholarship on gender and the DDR process similarly argues that unless reintegration programming integrates a 'gender framework' that considers women's practical questions, women are more likely to face special challenges in post-war settings because of gender, culture, ethnicity, location, and other identities (Cockburn 2001; Zuckerman and Greenberg 2004).

A study by McKay and Mazurana (2004) offers empirical findings on the lived experiences of female combatants in Uganda, Sierra Leone and Mozambique and their difficulties in starting new lives post conflict. One of the major findings suggests that due to DDR officials' lack of knowledge about girls' and women's issues, women faced larger exclusions. For instance, young female ex-combatants with war-born children faced extreme difficulties such as health issues, a lack of proper treatment and stigmatisation; issues which were not addressed in the DDR policies. Another study conducted by Mackenzie (2009) points out that in Sierra Leone, DDR failed to serve former female combatant needs because it was guided by gender stereotyping, neglecting women's roles in the conflict and limiting their war roles to either bush 
wives, abductees, or spying. In her study, McKay (2004) found girls hesitate to reintegrate after return because they find themselves in an untenable situation and unable to financially support themselves. Thus, they often migrate to an urban setting in hopes of escaping and finding a means of economic survival. Also, work by Honwana (1999) showed women ex-combatants faced difficulties after their return and were rejected largely by their families because they had experienced bloodshed, an act considered culturally to be damaging to the spirituality of the society. Further research conducted in Sri Lanka on female ex-combatants in the Liberation Tigers of Tamil Eelam (LTTE) by Azmi (2015) revealed that after going home, LTTE female ex-combatants were often assumed to have perpetrated violence in the war, and at the same suspected of being sexually abused. Such stereotyping demoralised and hampered their social reintegration process. These studies demonstrate that reintegration programs offer are often inadequate for women in post-war settings, and DDR policies are often based on preassumptions that 'normalcy' is regained after return to the community, without going in-depth into women's practical needs.

On the other hand, a few studies have found different outcomes to women ex-combatants' reintegration processes. Research in Northern Uganda reasons that some female ex-combatants reintegrated better and were more resilient through the family support (Annan et al. 2011). Similarly, a studies by Ortega (2015) in El-Salvador and Hauge (2008) in Guatemala showed women ex-combatants who organised collectively after they were demobilised and formed women ex-insurgent organisations, finding ways to benefit themselves and the community.

What all these studies show is that reintegration is context-specific and female ex-combatants face different experiences during the process. Challenges faced during reintegration are often the outcome of cultural-social prejudices, gender stereotyping, failings of reconciliation programming between combatants and community and a woman's pre-conflict situation in the communities. Other factors include knowledge gaps in DDR officials who design the reintegration programs and a lack of a gender framework in the DDR process. Whereas in the case of El-Salvador, Guatemala and Northern Uganda, women ex-combatants were not always marginalised after their return, but rather with family support and collective action they showed resiliency and/or brought positive changes to the society. In the same vein, the literature also sheds light on the roles of the community/family in whether women remain or opt to leave a community after returning. To date, the literature to date on gender and reintegration is rich, although there is little in the context of women and Nepal. This ethnographic study contributes 
to the body of literature by presenting how Maoist 'verified' women ex-combatants in Nepal faced re-marginalisation during the reintegration process and showing how the women felt their contributions made during wartime were devalued and made invisible, offering them limited options in a post-conflict setting.

\subsection{Methodology}

This paper employed in-depth interviews, key informant interviews and focus group discussions. The interviews were conducted by the author, a Nepali, in the framework of $\mathrm{PhD}$ research. Thirty-five Maoist women ex-combatants were interviewed for this study. In addition, four focus group discussions were conducted with women ex-combatants and key informant interviews with local leaders. Finding female ex-combatants for interviews proved very challenging. The study was conducted in Chitwan district of Nepal. To get access to women ex-combatants, at first, Maoist political leaders were contacted, drawing on earlier networks. They provided the contact details of five former Maoist commanders, who then provided contacts of a few women ex-combatants in various districts of Nepal. Later, contact was established with women ex-combatants currently living in Chitwan, and these women supported to established contacts with other ex-combatants' women from Chitwan. The fieldwork lasted from January 2014 until February 2015 and was conducted in various episodes. Before starting the field work, two exploratory visits were made in December 2013 and January 2014.

The interviews lasted from two to three hours each and follow-up visits were made to the same women several times. The interviews were conducted entirely in Nepali and audio-recorded after getting consent from the interviewees. After collection, the data were translated in English then coded and analysed using Atlas ti. software. To maintain confidentially of the interviewees, all the names applied in this paper are pseudonyms, but the participants' gender, caste and ethnicity are retained in the surnames. 


\subsection{Context: The Disarmament, Demobilisation and Reintegration (DDR) Process in Nepal}

This section first provides a brief explanation on Nepal's DDR process and later gives detailed explanations on how Maoist 'verified' women combatants experienced reintegration programming and how it affected their everyday realities after their return.

\subsubsection{Disarmament}

The DDR process was a key agenda of the comprehensive peace accord (CPA) and as per the CPA, the Maoist Party of Nepal and the Seven-Party Alliance members consented to invite the UN to assist and monitor the peace process (NIPS 2013). On January 23, 2007, the UN Security Council passed resolution 1740 to mandate the United Nation Mission in Nepal (UNMIN). The fundamental task of UNMIN was to monitor and manage arms and armies (ibid). Initially, the DDR process started with an agreement signed on December 8, 2006 between the Government of Nepal and the Maoist party to monitor the management of arms and armies (AMMAA), this agreement formed another sub-committee, the Joint Monitoring Coordination Committee, who set-out criteria for registration and verification of Maoist armies (News 2007).

Disarmament started with a voluntary and collective weapon submission under the support of the UNMIN and was unlike the conventional 'one gun, one combatant' disarmament method (Subedi 2014), in which even combatants who did not have weapons were considered Maoist combatants, based on their interview process. Altogether 3,475 weapons from the Maoist 'side' were registered and stored in the containers inside the Maoist cantonments. Similarly, from the Nepal Army side, a total of 2,855 weapons registered and placed in the containers inside army barracks. All these registered weapons were closely supervised by an authorised body (Subedi 2014).

The registration of Maoist combatants then began in January 2007 with the UN teams collecting personal military information and examining identity cards. The possession of a weapon was not a criterion for registration, but presentation of a Maoist army identity card was required to demonstrate service (Subedi 2014). Two conditions of eligibility for verification were set: candidates were only eligible if they joined the Maoist army before May 25, 2006 and were born before May 25, 1988 (NIPS 2013). With the completion of the registration and 
verification process, Maoist ex-combatants were categorised as either 'verified' (yogya) or 'disqualified' (ayogya). The verification process was controversial because disqualified combatants claimed that the set criteria for verification from their own leadership abandoned them and disregarded their service in the Maoist war (NIPS 2013, Subedi 2014).

At first, a total of 32,250 combatants were registered to be verified, however, not all registered combatants qualified (Subedi 2014). In the second phase, only 19,602 combatants of the original group (15,756 men and 3846 women) were declared 'verified', meaning they qualified for entitlements of Maoist ex-combatants. Over 4,000 candidates were considered 'disqualified' and 8640 ex-combatants did not return for the second-round verification interviews so were automatically discharged (Bhandari 2015).

\subsubsection{Demobilization}

As part of the demobilisation agreement, cantonment sites or camps were established to temporarily settle Maoist combatants. Verified combatants were stationed in 7 main cantonments and 21 satellite cantonments across the country; the weapons were also stored in the cantonments under supervision of authorised personnel (Martin 2012). The disqualified combatant group was immediately demobilised after the conclusion of the verification process and later called to participate in the rehabilitation training offered by the United Nation Interagency Rehabilitation Programme (Subedi 2014c), whereas the verified combatants remained in the cantonments until the reintegration programming was finalised in 2012 (Subedi 2014c).

\subsubsection{Reintegration}

According to the CPA agreement, the Government of Nepal formed a special committee in October 2008 chaired by the Prime Minister and represented by the major political parties, the UN and Maoist leaders. The committee remained the highest authority to design reintegration modalities, including supervision, integration and rehabilitation of the Maoist ex-combatants (NIPS 2013; Bhandari 2015). Reintegration turned out to be very controversial because at that time various political parties were involved in reintegration programming decision making and had their own interests in mind. Thus, consensus building among different political parties about reintegration program options remained a major challenge, which prolonged the 
reintegration process. The six-month timeframe for completing the DDR process took nearly five years. Finally, in November 2012, all the major political parties signed an agreement that offered three reintegration options for ex-combatants: i) integration into the Nepal army, ii) voluntary retirement with a cash compensation or iii) a rehabilitation package that included educational support and vocational training opportunities (NIPS 2013; Bhandari 2015).

However, despite the options given, the reintegration programming was designed to be largely cash-based (Subedi 2014). The delivery mechanism was coded in such a way that the majority of women ex-combatants ended-up choosing cash compensation. For instance, the army option was not realistic for many women because of competitive entrance criteria (age, education levels, etc.) and did not allow for women who already had child-caring duties. By the same token, the rehabilitation option required some knowledge of math, English, reading and writing, which many women lacked. Thus, even if women showed interest in the first two options, they were likely to be excluded from these and 'forced' to choose the cash compensation. Compensation was delivered on the basis of rank, meaning ex-combatants of the highest rank received between NPR 500,000-800,000 (USD 5,000-8,000) depending on rank (Subedi 2014a; Bhandari 2015). Among 19,602 verified combatants: 15,624 opted for voluntary cash-retirement, 1,422 integrated in the Nepal army and only six chose the rehabilitation package (ibid).

\subsection{Zooming in on the Reintegration Process: What did it Offer Verified Women Ex- Combatants?}

Understanding women's everyday lives and their experiences informs what reintegration means to them and the challenges they encounter while transforming from a combatant civilian role. In this section, I will first highlight how a gender framework was not adopted in the DDR process at the level of discourse and particularly in reintegration programming. Then I will present the women ex-combatants' lived experiences as they went through the reintegration process. Finally, based on these analyses, I offer conclusions about gender and the DDR process for Maoist women ex-combatants.

I will first show how a gender framework was not adopted during the DDR process and how it remained gender discriminatory. Firstly, the CPA was the fundamental guiding document to implementing the DDR process, however, it does not provide a clear methodology to address 
women's issues in post-conflict reintegration. It mentions: “... to address the problems of women... by deconstructing the current centralised and unitary structure, the state shall be restructured in an inclusive, democratic and forward-looking manner" (CPA 2006, p.3). Such an unclear implementing approach to bring gender inclusion in the CPA itself further produced reintegration programming gender-discrimination. Secondly, Nepal's DDR process remained highly male-centric, meaning that DDR planning and management were conducted solely by men and excluded women ex-combatant's voices. Thirdly, because the reintegration compensation package (cash and training) would be provided equally to women and men excombatants, the DDR implementers assumed that 'gender equality' would be inherent in such treatment. Lastly, DDR personnel assumed that women ex-combatants would return home along with their compensation money and their lives would be automatically 'resumed', without realising the fact that simply returning does not necessarily equate to regaining a normal life, but is rather, as a post-conflict situation, a period filled with transitions at different levels.

All of the verified women ex-combatants interviewed for this paper were initially interested in the option to integrate into the army, particularly because the offer was for permanent positions, but many women found this option too vague. For example, in the beginning, the peace accord committed to integrating all interested Maoist ex-combatants into the army, but afterwards it imposed restrictions around minimum education, age and other military training experience as requirements for this option. As previously mentioned, such criteria restricted women from choosing this option. Considering the overall percentage of combatant's entry into the Nepal army was small, only 1,422 combatants (104 female) were offered posts (Bhandari 2015). Goswami (2015) points out, "only a small number of Maoist women were able to meet the eligibility criteria for [Nepal army] integration, which raised considerable resentment” (p.8).

Binita Magar explains how the reintegration process was unclear to her and how she realised her exclusion from the Nepal army:

I wanted to go for integration into Nepal Army (NA) this was government's permanent job ...but to enter NA criteria of education, and skills were very strict...I am uneducated, and never went to school, so I could not think of going for this option. I felt excluded when I heard this news, because before we were told that Maoist combatants those who wants to 
join NA can get direct integration ... later found the process was unclear and gave me a big surprised. (Interviewed November 2014, Chitwan).

The female ex-combatant Nirmala Gurung also shared her story of how she was not able to gain entry into the army:

I wanted to opt for integration into Nepal Army but at that time I already crossed 30 years of age...so over-aged, including lack of education I was excluded. I really felt abandoned from my own Maoist party for signing such an agreement which is not in our favour, Maoist party also did not discuss with us (women) our reintegration planning, and our future priority. (Interviewed July 2014, Chitwan).

Other accounts show how reintegration ignored women's issues. A verified woman excombatant, Kirtika Tamang, shared her story about the reintegration process, and how she felt it was a false promise.

While living in the cantonment I got married, later in 2011, I became a mother, during that time mothers were not obliged to stay in the cantonment, thus, I went to my village to meet my parents. My village is in very remote area (almost 3 days walk) from the local bazar, at that time debate on integration into Nepal Army was heated. To enter Nepal Army many requirements were raised by the political party who were in the government...I had a small baby and travelling from village to appear for Nepal Army integration examinations and interviews were impossible to my situation and that's why I had to quit my decision. (Interviewed May 2014, Chitwan).

Another woman discussed her health issues and how the reintegration program neglected the health concerns of combatants who were wounded in the war.

In the war I got wounded; there were several bullets in my body. I received treatment when I was in the cantonment, but later after returning back... I get sick often... due to my unwell treatment of old bullets wounds; sometimes I get bleeding....and often get body pain and headache...need to travel to hospital. I have invested all my compensation money into my health...now I am facing financial crisis very difficult to survive ...when I am sick my households turn completely into disaster... Including my child suffers due to lack of my care during that time. (Bijaya Magar, Interviewed July 2014, Chitwan). 
The above illustrations show that entering the Nepalese army was not an option for most female ex-combatants. Likewise, other women, like Kritika Tamang, show that mothers with infants or young children were unable to access integration programs due to travel restrictions and childcare duties. In Nirmala Gurung's case, the main reason for her exclusion from the army was due to her age. Binita Magar's case shows she lacked the education and skill to meet the army requirements and was automatically discharged. Similarly, Bijaya Magar's narrative illustrates that because her war-borne health issue was not considered in the reintegration planning and due to a lack of alternatives, she was compelled to use her cash compensation for health treatment. Currently she is facing adversity in re-organising her life.

The above women's accounts also reveal that the Maoist commitment to gender equality was not upheld during the reintegration period. Although the 'people's war' offered empowering experiences to these women from different backgrounds, after demobilisation their combat roles and positions were devaluated, creating an uncertain sphere and trapping them into undesirable gender roles (K.C. and Van der Haar 2018). Overall, women were not able to find validation of the experience and skills they acquired as combatants and instead, faced 'remarginalisation'. As Goswami (2015) claims, "it is crucial that representation to design reintegration planning must be from those who understand and have lived experiences of social inclusion, gender justice, and rights" (p.14).

\subsection{Reintegration Experiences: Cash Compensation}

As discussed in the previous section, most of the female ex-combatants were unable to access the full range of reintegration programmes. This section provides Maoist female excombatants' experiences with the cash compensation option, and how this shaped their everyday lives in various ways after returning to their communities.

Padma Thapa shared her story about how she made the decision to choose cash compensation and how she manages living from this settlement:

Before me and my husband both were interested to join Nepal army, but we failed to meet the requirements... and decided to go for cash compensation... we both each received NRs. 500,000 [USD 5,000], and bought unregistered land [10 dhur, or about 170 square meters] in remote area, because with this amount we could only buy such types of land...I cultivate maize and 
sometimes vegetable for household purpose...my husband work as an agriculture labour and his work is irregular...until now I did not find any job yet...including I bought unregistered land and its under my husband's name what worries me the most is... whether I will be able to get the legal land registration certificate or not what will happen if my husband deny to give the portion of the land in the future. (Interviewed November 2014, Chitwan).

Sarita Rai shares her story why she decided to go for the cash compensation and how this has impacted her daily life:

I feel like a nightmare now... Before I thought I would buy a land and build a house with the cash compensation, but after returning, I could not go back to my village as no one is living there right now, my mother died few years before, and my father married another woman...so I decided to live in Chitwan district. Nowadays, living is very expensive. I spent the cash compensation just to meet my daily needs like paying rent, food, paying my kids school fees...now almost spent the entire amount. Now difficult time has come in my life... I could not sleep... thinking how I will take care of my children, and my family... I contacted my Maoist friends to search any type of job for me...like agriculture labour or maid this is what I can do as I am not educated and now old, nothing found yet. (Interviewed June 2014, Chitwan).

Bimala Thapa, another participant, also shared her situation after returning:

While living in the cantonment for long time we do not have to pay our rent, or for our food, but as soon as we were discharged...we had to bear our sole responsibility such as rent, food, clothes, health care, child care, travel etc. I became very nerves after I came to the community...thinking how I will make my living... with our first instalment...I and my husband spent paying the rent, food, paying child school fees and health care...but after some time I realized what I am I going to do after finishing all cash?... So with our second instalment amount we bought tiny piece of land but my husband kept ownership in his name... I could not say anything; hope he will not betray me. Another problem...cash compensation was delivered in two instalments therefore difficult to invest immediately, buying land or start small business...Later, after few months when next instalment was given, the land and goods price went high. (Interviewed November 2014, Chitwan). 
One of the other female ex-combatants, Sanu Tamang, relayed her husband's reaction when she raised the issue of transferring land to her name or in a joint agreement: first he remained silent, then later blamed her as mistrusting him about a tiny piece of land, and then further questioned her if she was planning to run away with another man and take the property. On the other hand, another woman, Maiya Thami, described her experience investing the cash together with her husband much more equally:

We both received equal amount of (USD 6,000 each of us), we invested this amount together to buy a small piece of land, and we decided to issue combined land ownership certificate, so we have equal rights on it... His relatives many times suggested him to maintain single ownership, but my husband refused. (Interviewed July 2015, Chitwan).

From the above accounts, it is clear that some women invested together with their husbands to buy a piece of land, others used the finances to maintain their everyday needs and a few looked for further financial support from family. The ways in which the women invested the cash to buy property illustrates a priority to regenerate life (or a livelihood) and create a certain future. However, the predominant challenge that emerged was having to renegotiate access to the property rights, of which the majority of the women were still dominated by their husbands. As men retain the land-ownership and these women resisted upon the action. It was surprising to note that only one-woman, Maiya Thami, owns the property (land) together with her husband, despite that her husband faced displeasing remarks from other family members while maintaining joint land ownership. Yet Sarita Rai's narrative told a different story about how she was unable to invest her cash compensation to buy property due to a lack of alternatives and need to fulfil her family's needs, and now she is still struggling to survive. All these examples illustrate how women's roles and power were diminished once they resumed their places in families and communities that operate through a patriarchal process.

The explanations further show how women each encountered different experience in their everyday lives in the post-war situation. Although in the war, women were able to transform into new roles as soldiers, this did not, however, equate to achieving 'equality' in the period after the war. Rather, this post-war period perpetuates new forms of isolation and marginalisation. The cases of Padma Thapa, Bimala Thapa, and Sanu Tamang shows how their husband's treatment is ambiguous; on the one hand, these men were Maoist ex-combatants aware of Maoist ideology to gender equality and they chose to marry women ex-combatants 
who challenged the normative cultural boundary, unlike non-combatant men. On the other hand, their attitudes to exclude their wives' ownership of the shared property reflects patriarchal norms. Other scholarly work has similarly found that conflict does not necessarily change the mind-sets of the individuals in aftermath of war, rather patriarchy is highly maintained (Enloe 2004; MacKay 2004). The narrative of Maiya Thami discloses how her husband encountered societal pressure from his family to retain the property under his single authority. However, they both challenged the patriarchal practice and issued the property ownership jointly. This shows how they are fighting back to establish gender equality in everyday life in post-war era. In addition, the story of Sarita Rai proofs that cash-compensation is a short-term option for reintegration which does not assure long-term survival and might produce a longer-term crisis.

The narratives also demonstrate how the cash compensation method was not planned in such a way as to be most beneficial to women ex-combatants. For instance, the narrative analyses identify several factors common to the female ex-combatant stories of how they utilised the cash compensation. Common factors include relocation to a new area, lack of alternative support (such as family or parents) and job crisis. To this point, some of the women spent their cash settlement pay for rent, food, children's school fees, and health care. Cash-delivery without guidance or training on how to use it is problematic because for many years this group of people was living in a collective manner, under military training, away from the job market and the community. At that time, the party was responsible for the combatants and they were not exposed to societal norms such as how to run a typical family, how to find a job or how to deal with daily challenges that might arise without party support. Also, the cash compensation delivery method into two instalments played a role to women's post-war decisions, i.e. the first instalment provided half of the amount, and women were unable to instantly afford to invest in the property with that money; the second instalment was delivered after one year, by this time the property prices were already climbing compare to previous year. Therefore, with the remaining fund few of them were able to purchase a tiny piece of land in a remote area, while others ended of fulfilling their basic needs. 


\subsection{Maoist Women Ex-Combatants: Visible in Conflict and Invisible in the Aftermath of} Conflict

The study shows how women ex-combatants felt they became invisible in post-conflict Nepal. This section shows how they are renegotiating their roles in the Maoist political landscape and identifies some mechanisms that contribute to their marginalisation in the reintegration period.

As previously mentioned, the CPA became the core instrument guiding the DDR process in Nepal, yet the development of the CPA was highly male-centred, no women were included in negotiating the comprehensive peace agreement (Yadav 2016). Similarly, when a six-member committee was formed to develop an Interim Constitution in 2006, initially no women were included either from the Maoist or the government side. Eventually, after continuous pressure from female politicians and protestors, the committee expanded to include four women (Yadav 2016). Representation of women was also lacking in the committees that were formed to implement and manage the DDR process (Goswami 2015).

This larger story of the exclusion of women from the highest level of political decision making is reflected in the stories of individual women within their communities. For instance, Bimala Thami describes how she was re-marginalised from Maoist local politics after returning to her community:

\footnotetext{
After returning to the community, I am interested in continuing my career in Maoist politics... I started building a network with the local Maoist leaders and community ... And also participated in their local companions, but later during the time of Maoist party internal election they said that I lack political experience and knowledge to hold any positions in the local politics ... The reasons they gave me is that I served in the Maoist combat force, and my previous war experience does not fit to qualify in core local politics. The exclusion is also because the mainstream politics of Maoist party are mostly led by people who were not previous combatants. (Bimala Thami, Interviewed July 2014, Chitwan).
}

Other factors explaining why woman ex-combatants were side-lined and excluded from local politics are a lack of access to monetary resources and too many household responsibilities:

Since the beginning I wanted to join Maoist politics and become a leader. I went into the war to fight for rights ... now after the war and having small children and households my husband 
and family do not allow me to participate in the politics ... also I realised for doing politics or win election (any positions) it requires resources like money, and I do not have access to such resource ... these things kept me away from the local politics and beyond. (Puja Rai, Interviewed Jan. 2015, Chitwan).

Gita Lamichane also shares her story about why she was excluded from the Maoist mainstream politics:

I am an ex-combatant, and our leaders think that we are only good for fighting, that's why they do not include us in the mainstream politics ... Also, to come in the politics and gain a position one must be close to Maoist top or local leaders, but after demobilisation, I mostly contacted Maoist ex-combatants and live within the surroundings of our war peers, and to get into such political access it is very challenging and particularly for woman it is very difficult. There are many prejudices for woman going into the politics. (Interviewed June 2014, Chitwan).

These accounts illustrate the everyday mechanisms that marginalise ex-combatant women after demobilisation and, in particular, the difficulties they experienced as they tried to enter local politics. Bimala Thami's story reflects how Maoist leaders discounted her war leadership skills, challenged her acquired knowledge of politics in the war and blocked her participation in local politics. As she pointed out, the party came under the leadership of people who had not taken up combatant roles during the war and tended to discredit the ex-combatants. Likewise, the stories show how women may face a gender hierarchy in their own households and find it hard to act independently from their husbands who hold authority over them in everyday life.

The narratives support the argument that conflict-related changes in gender roles are limited to the timeframe of the war, and afterwards women are pushed systematically into traditional roles (Enloe 2004; Niner 2011). In particular, women encounter difficulties participating in the public sphere. Shekhawat (2015) suggests in this regard that: "it is the male-dominated leadership of a movement that decides what women will do and what not" (p.11). MacKenzie (2009) also found a similar situation in Sierra Leone and explains: "even when women participate in the activities of high politics or sectors traditionally categorised as security priorities such as conflict, they are effectively shuffled out of the public political sphere and into the domestic realm through post-conflict development policies" (p.243). 


\subsection{Family Matters: Re-Connection, Dis-Connection and the Everyday Realities of Reintegration}

This section analyses how women's personal experiences during reintegration were related to family acceptance or rejection. I show how regular/irregular family ties and reciprocal relationships before and during the insurgency affected the women ex-combatant's everyday lives after returning from war. I also show how their war-peers form a sort of alternative 'family' and support network, especially when the women did not return to their villages of origin.

The Maoist woman ex-combatant, Sapana Tamang, shares her experience after her return and the role of the family in this process:

During the Maoist insurgency, I contacted my family (mother, father, uncle) by phoning, sending letters and messages via friends, also a couple of times I borrowed money from my family, later I also sent money home through my Maoist friends. I informed my family about my arrival and they welcomed me after coming home. I stayed with them along [with] my husband and son for almost four months before we decided to move to Chitwan and settle. Family support gives lots of strength to continue ordinary life ... when people know I have my family support they don't dare to say anything easily upfront, if I have any problem I share to my parent and sibling. I live in Chitwan because my husband run small grocery shop, and sometimes I support him, mostly I look after my households, including I want to live here due to my son's education. (Interviewed November 2014, Chitwan).

Another account, from Sanu Bam, emphasises reunification with her family in the aftermath of war and how, due to her mother's support, she was able to restart her life:

In the war time, I always updated my mother about my situation through friends and contacted her frequently ... we always had very close ties. When I came home after demobilisation... I became extremely sick during that time my mother took care of my baby. Also, she helped me financially; for example, partially paid my hospital bills, including in my other hard times she stood along with me. (Interviewed July 2014, Chitwan). 
The next story from Rekha Limbu details her situation after going home:

My father died ... I could not attend his funeral. Also, I joined Maoist party against my family agreement, and they rejected me after I returned home ... they feel I am still harmful ... now I rely upon Maoist ex-combatant's network. Currently, together with my husband I operate a small grocery shop, initially I could not invest entire cash-compensation money into my business because I utilised this money also for child education, paying the rent and other daily expenses while settling to a new place. Therefore, to start grocery business I borrowed some money from my Maoist friends. (Interviewed January 2014, Chitwan).

Another former combatant, Sunita Rai, explains how she faced exclusion after returning. Her experience is particularly relevant to the issue of gender-based discrimination in the community, which existed in the pre-war situation, and how such practices continued even in the aftermath of war:

After going back home I am living with my Maoist war peers. I was away from house for almost 7 years, I did not dare to contact my family as I knew they would never accept me. My family don't want to see me now, they hate me because I went to Maoist war, against their permission. Being a girl, they think that war is only for men...women must work at home. My neighbour also thinks being woman and going in a war I committed sin. In case of my husband, he is also a former Maoist combatant, but my neighbour and his family treat him respectfully, talk with him, and listen to him, very different from what I experience. (Interviewed February 2014, Chitwan).

From the accounts of women ex-combatants, it becomes clear how significant the role of family is during the reintegration process and how family support - or lack of it - may make the experience of returning to civilian life very different. Women who sustained relationships with their families during wartime, and/or whose families kept liberal views towards the Maoists party, found that family reception became a source of security and help to restart a 'normal life'. On the other hand, women whose families were against the Maoist party or disliked their female members entering the party were unable to resume family relationships during the war as well in the post-war period and consequently, were more likely to find reintegration period more difficult. In case of Sapana Tamang, she maintained strong family ties during the insurgency, sending letters, money and updating family members on her situation. In response, she received a warm welcome when returning home together with her husband and son. In fact, she was able to return home and did not even encounter the pressure of immediately paying 
rent, which allowed her time to consider a new location to settle. Similarly, the narrative of Sanu Bam reveals that her mother's support became an extra strength helping to rebuild her life, i.e. taking care of Sanu and her baby while she was ill and helping her emotionally and financially. It is clear that family support offered her protection in facing hardships while returning to normality.

In contrast, in the case of Rekha Limbu, resuming a family relationship became a challenge. Her recruitment into the Maoist party was against her family's wishes, and as a result, she was unable to maintain ties with her family during the war and faced rejection after returning. To restart her life, she used the cash-compensation money to pay the rent and other needs and she borrowed money from her Maoist network to start a business. Similarly, Sunita Rai also joined the Maoists against her family's will and subsequently was not able to retain her family relationships throughout the war and in its aftermath. After going home, her family and the community accused her of breaking traditional feminine roles, whereas her husband (who is also Maoist combatant) did not face such stereotyping. These narratives of rejection and estrangement also highlight how the absence of family support produced a new form of isolation, and the women's successful reintegration became mostly reliant on the network of Maoist peers.

\subsection{Conclusions}

The paper provides a gendered analysis of the post-war situation of Nepal, showing what realities Maoist women ex-combatants faced during the reintegration process. Firstly, the paper displays how the reintegration process remained strongly male-centred, particularly in terms of the comprehensive peace accord and the reintegration programme itself. Not taking up a serious gender agenda in the reintegration programming had the following consequences: reintegration programming failed to include women ex-combatants' voices on issues that women were most likely to face, such as the search for employment, physiological challenges, child care, young mothers, health issues, re-establishing womanhood and encountering social prejudice. For instance, if women moved to a new area, the dislocation often resulted in a lack of alternative support in caring for children, which had a negative impact on their ability to find employment or build a career. The military skills gained from the war were neglected while their feminine roles as mothers or wives were rather emphasised and welcomed in the post-war context. 
Similarly, upgrading women's skills and education were non-prioritised, and women found themselves unable to fit into the current job market.

Secondly, the paper finds that the reintegration period is ambivalent. Earlier Maoist ideology offered a strong message of gender equality and attracted high numbers of women to the movement, yet once the Maoist party took over political power, they returned to highly patriarchal processes turning women ex-combatant's invisible in both the national and local Maoist political landscape by discounting their war leadership skills. Also, some women underwent a two-fold rejection while expressing their political interests; both from their husbands and from the party leadership. As a result, despite having political interests, these women are forced to live in a system that operates on masculine power in the private as well in the public spheres.

These practices produced new forms of isolation, inequality and marginalisation in post-war context. The new roles women gained in the war were devalued, which tended to push them into undesired roles. Such practices also pose a question about Maoist 'gender equality' which, for the women ex-combatants, seemed to vanish in the aftermath of war, reflecting how the culture of masculine power does not necessarily transform from war. In addition, the paper shows that in most cases, the essence of patriarchy operates in all aspects of everyday life and restrains women to a powerless position.

Thirdly, the paper demonstrates that despite the fact that 'verified 'women ex-combatants successfully participated in the entire DDR process, they still faced gender-based exclusion afterwards. Unlike in other cases discussed in the literature, this exclusion does not already happen in the disarmament phase, but later, during the reintegration phase. This means that there is no guarantee that even after women make an entry into the DDR programs, they will not face exclusion and marginalisation in the period after. Finally, the paper found that family/community reception played a role in the reintegration timing, for instance; women excombatants who maintained reciprocal relations with their family during insurgency, and whose family were loyal to Maoists party face smoother reintegration to resume their life in normal setting. In contrast, women, ex-combatants from non-Maoist family backgrounds, including those who entered the Maoist against family agreement were unwelcome during reintegration. Consequently, they faced social isolation and had to rely almost exclusively on the networks of war peers. 


\subsection{References}

Annan, J., Blattman, C., Mazurana, D., \& Carlson, K. (2011). Civil War, Reintegration, and Gender in Northern Uganda. Journal of Conflict Resolution, 55(6), 877-908. https://doi.org/10.1177/0022002711408013

Azmi, F. (2015). IWantMyWings Back to Fly in a New Sky: Stories of Female Ex-LTTE Combatants in Post-War Sri Lanka Fazeeha. In S. Shekhawat (Ed.), Female Combatants in Conflict and Peace: Challenging Gender in Violence and Post-Conflict Reintegration (pp. 200-2015). London: Palgrave Macmillan.

Bhandari, C. (2015). The Reintegration of Maoist Ex-Combatants in Nepal. Economic \& Political Weekly, (9), 63-68.

Cockburn, C. (2001). The Gendered Dynamics of Armed Conflict and Political Violence. In C. O. N. Moser \& F. C. Clark (Eds.), Victims, Perpetrators or Actors? Gender, Armed Conflict and Political Violence (First, p. 236). London: ZED Books.

Colekessian, A. (2009). Reintegrating Gender: A Gendered Analysis of the Nepali Rehabilitation Process. Santo Domingo, Dominican Republic. Retrieved from https://reliefweb.int/sites/reliefweb.int/files/resources/4DF98D25D63E5852852577CA00 683717-Full_Report.pdf

CPA. Comprehensive Peace Accord (2006). Kathmandu Nepal: Government of Nepal.

Dahal, S. (2015). Challenging The Boundaries The Narratives of the Female Ex-combatants. In S. Shekhawat (Ed.), Female Combatants in Conflict and Peace: Challenging Gender in Violence and Post-Conflict Reintegration (pp. 185-199).

Denov, M., \& Ricard-Guay, A. (2013). Girl soldiers: towards a gendered understanding of wartime recruitment, participation, and demobilisation. Gender \& Development, 21(3), 473-488. https://doi.org/10.1080/13552074.2013.846605

Enloe, C. (1993). The Morning After: Sexual Politics at the End of the Cold War,. Berkeley: Berkeley:University of California Press.

Enloe, C. (2004). The Curious Feminist Searching for Women in a New Age of Empire.

Gautam, N. (2009). Nepal : Peace Process Heading South. Economic and Political Weekly, 44(49), 8-13.

Goswami, R. (2015). UNSCR 1325 and Female Ex-Combatants-Case Study of the Moiast Women of Nepal. New York.

Hauge, W. (2008). Group identity—a neglected asset: Determinants of social and political participation among female ex-fighters in Guatemala. Conflict, Security \& Development, 
8(3), 295-316. https://doi.org/10.1080/14678800802323316

Humphreys, M., \& Weinstein, J. M. (2005). Disentangling the Determinants of Successful

Demobilization and Reintegration. Annual Meeting of the American.

https://doi.org/http://dx.doi.org/10.2139/ssrn.984246

K.C., L. (2011). Securing Livelihoods: Reintegration of Former Mother Combatants with

Children in Post-Conflict Nepal. Wageningen Unversity \& Research.

K.C., L., Van Der Haar, G. and Hilhorst, D. (2017). “Changing Gender Role: Women's

Livelihoods, Conflict and Post-Conflict Security in Nepal.” Journal of Asian Security and International Affairs 4 (2): 175-195. doi:10.1177/2347797017710743.

K.C., L.\&Van Der Haar, G. (2018): Living Maoist gender ideology: experiences of women ex-combatants in Nepal, International Feminist Journal of Politics. https://www.tandfonline.com/doi/full/10.1080/14616742.2018.1521296

Knight, M., \& Özerdem, A. (2004). Guns, camps and cash: Disarmament, demobilization and reinsertion of former combatants in transitions from war to peace. Journal of Peace Research. https://doi.org/10.1177/0022343304044479

MacKenzie, M. (2009). Securitization and Desecuritization: Female Soldiers and the Reconstruction of Women in Post-Conflict Sierra Leone. Security Studies, 18(2), 241261. https://doi.org/10.1080/09636410902900061

Martin, I. (2012). The Unitee Nations and Support to Nepal's Peace Process: The Role of the UN Mission in Nepal. In von S. Einsiedel, M. D. Malone, \& S. Pradhan (Eds.), Nepal in Transition From People;s war to Fragile Peace (p. 383). Cambride University Press.

Mazurana, D. (2013). Women, Girls and Non-State Armed Opposition Groups. In C. Cohn (Ed.), Women and Wars (pp. 146-168). UK: Polity Press.

Mazurana, D., \& Cole, L. E. (2013). Women, Girls and Disarmament, Dembolization and Reintegration. In C. Cohn (Ed.), Women and Wars (pp. 194-214). Cmabridge.

McKay, S. (2004). Reconstructing fragile lives: Girls' social reintegration in northern Uganda and Sierra Leone. Gender and Development, 12(3), 19-30. https://doi.org/10.1080/13552070412331332280

Mckay, S., \& Mazurana, D. (2004). Where are the girls? Girls in fighting forces in Northern Uganda, Sierra Leone, and Mozambique. Their lives before and after war. Gender Studies Database.

Muggah, R. (2005). No Magic Bullet: A Critical Perspective on Disarmament, Demobilization and Reintegration (DDR) and Weapons Reduction in Post-conflict Contexts. The Round Table, 94(379), 239-252. 
https://doi.org/10.1080/00358530500082684

Nepal Institute for Policy Studies. (2013). Nepal's Peace Process : A Brief Overview Nepal Institute for Policy Studies ( NIPS ). Policy Paper (Vol. 8). Retrieved from http://www.nipsnepal.org/pictures/publication/Z5C_Nepal's_Peace_Process_A_Brief Overview_English.pdf

News, U. (2007). UN starts process of disarming Nepalese ex-combatants. Global Perspective Human Stories, p. 1. Retrieved from https://news.un.org/en/story/2007/01/206082-unstarts-process-disarming-nepalese-ex-combatants

Niner, S. (2011). Hakat Klot, Narrow Steps. International Feminist Journal of Politics, 13(3), 413-435. https://doi.org/10.1080/14616742.2011.587371

Ortega, L. M. D. (2015). Untapped Resources for Peace: A Comparative Study of Women's Organizations of Guerrilla Ex-Combatants in Colombia and El Salvador. In S. Shekhawat (Ed.), Female Combatants in Conflict and Peace: Challenging Gender in Violence and Post-Conflict Reintegration (pp. 232-249). London: Palgrave Macmillan. Özerdem, A. (2002). Disarmament, demobilisation and reintegration of former combatants in Afghanistan: Lessons learned from a cross-cultural perspective. Third World Quarterly, 23(5), 961-975. https://doi.org/10.1080/0143659022000028558

Özerdem, A. (2012). A re-conceptualisation of ex-combatant reintegration: 'Social reintegration'approach. Conflict, Security and Development, 12(1), 51-73. https://doi.org/10.1080/14678802.2012.667661

Özerdem, A., \& Podder, S. (2011). Child Soldier: From Recruitment to Reintegration. London: Palgrave Macmillan.

Pandey, N. N. (2009). Security Sector Reforms In Nepal: If not Now, When? South Asian Survey, 16(2), 253-271. https://doi.org/10.1177/097152310901600206

Podder, S. (2012). From recruitment to reintegration: Communities and Ex-combatants in post-conflict Liberia. International Peacekeeping, 19(2), 186-202. https://doi.org/10.1080/13533312.2012.665696

Sharma, M., \& Prasain, D. (2004). “Gendered Dimensions of the People's War: Some Reflections on the Experiences of Rural Women. In M. Hutt (Ed.), Himalayan People's War: Nepal's Maoist Rebellion (pp. 152-64). Bloomington: Indiana University Press. Shekhawat, S. (2015). Female combatants in conflict and peace: Challenging gender in violence and post-conflict reintegration. Female Combatants in Conflict and Peace: Challenging Gender in Violence and Post-Conflict Reintegration. London: Palgrave Macmillan. https://doi.org/10.1057/9781137516565 
Subedi, D. B. (2014a). Conflict, Combatants, and Cash: Economic Reintegration and Livelihoods of Ex-combatants in Nepal. World Development, 59, 238-250. https://doi.org/10.1016/j.worlddev.2014.01.025

Subedi, D. B. (2014b). Discontents and Resistance of 'Unverified' Ex-combatants and Challenges to their Rehabilitation in Nepal. Agrarian South: Journal of Political Economy, 3(2), 203-237. https://doi.org/10.1177/2277976014550772

Subedi, D. B. (2014c). World development. World Development (Vol. 59). Pergamon Press.

Thapa, G., \& Sharma, J. (2009). From insurgency to democracy: The challenges of peace and democracy-building in Nepal. International Political Science Review, 30(2), 205-219. https://doi.org/10.1177/0192512109102437

Thomas, E. (2010). Between war and peace: Monitoring guidelines for child soldiers in Nepal's peace process. Journal of Human Rights Practice, 2(1), 93-121. https://doi.org/10.1093/jhuman/hup029

Yadav, P. (2016). Social Transformation in Post-conflict Nepal. Taylor and Francis:ProQuest Ebook Central.

Zuckerman, E., \& Greenberg, M. E. (2004). The Gender Dimensions of Post-Conflict Reconstruction. World, 12(3), 1-16. 


\section{Chapter 6: Exploring Gendered Effects of the 2015 Earthquake in Nepal through Women's Eyes}

The chapter is co-authored by Dorothea Hilhorst. 


\begin{abstract}
This paper is grounded in a series of intimate encounters, over a period of five months, with 22 women survivors of the Nepal earthquake. One of the authors was herself a survivor: she started the interviews while living under a plastic sheet in a field near her house. The study followed women in the evacuation, relief and recovery phases and the paper analyses the specific problems women faced. Problems encountered were different to some extent, especially with regard to gender and migration. Beyond the dramatic visible effects of the disaster, women great difficulties with regards to the repayment of interest on outstanding and new loans. Gender and disaster literature have emphasised that pre-disaster gender inequalities and practices lead to gender-specific problems in times of disaster. In Nepal, women felt illprepared by the strictures of traditional gender ways, especially in coping with livelihood challenges after the earthquake. A unique finding was that many women did not have citizenship certificates or other identity papers that were required for accessing government relief funds. Experiences from the earthquake made research participants conscious of their restrictions and some of them started transforming their roles. Whether this continued beyond the recovery phase is a question for further research.
\end{abstract}

Keywords: Women Earthquake Survivors, Gender Roles, Gender Inequality, Earthquake 2015 Nepal 


\subsection{Introduction}

This article has a special history. When an earthquake occurred in Nepal on 25 April 2015, the first author was in the country in the final stage of fieldwork on women's experience in the years following the Maoist conflict. The earthquake hit at 11:56 hours, and this is how she recalls it:

I was on the $3^{\text {rd }}$ floor of my parent's house in Bhaisepati near Kathmandu, chatting with my mother. We suddenly heard a very unusual noise, like the howling of a big storm, followed by a huge shake. The windows, doors and even walls of the room started shaking and swinging. We then felt a real tremble; I started screaming earthquake!! Earthquake!! Run, run!! I heard loud noises from all over at the same time. I tried to rescue my mother and myself, but she fell down because of the shakes and injured her legs and head. She told me to go down to open the main door, while my father who came from the next room stayed with her. On my way down I fell four times, hurting my knees.

When I came out of the house, neighbours were crying and screaming for help, and hundreds of families were already in the open field praying for their lives. Eventually, I was able to bring my parents to the field. That first night, we spent outside in a thunderstorm and heavy rain. We had nothing to protect ourselves: no tent, no umbrella, no raincoat, nothing. We had not eaten either. There were so many of us, and so many children.

We were instructed not to go back into the house, and our first preoccupation was to arrange for a tent. Fortunately, one of my neighbours had a big plastic cover for his car. We shared this as a makeshift tent with 20 people for two nights. All the medical services were closed, and it was only after two days that I could take my mother to the hospital to have her injuries attended to.

After this, my mind started to drift to what I saw around me. It is known that disaster survivors tend to hold on to normality as best as they can (Artur, 2011), so perhaps returning to my role as researcher provided me an anchor in the midst of the chaos. Through my research I was trained to look at trouble through women's eyes. Within a week after the earthquake I started to visit the participants of my study to listen to and document their stories.

In the following weeks, I visited Bungmati, a village $6 \mathrm{~km}$ away from my home town, Bhaisepati, which turned out to be the hardest hit by the earthquake. I frequently went to the area, sitting together with women, sharing my story and listening to theirs. Finding comfort in going through the academic motions of writing an earthquake field diary, I started to make notes every day about what I saw and heard around me - in between follow-up visits to the hospital with my mother and trying to survive under a small shelter.

After some months, when I was able to go back to the Netherlands where I was completing my PhD, I sat down with the second author (my supervisor) to sort out and analyse my notes, and the idea was born to write this article about the earthquake through women's eyes.' 
It has been convincingly argued that fully understanding disasters and their aftermath requires a gender lens. Disasters affect men and women differently, and gender is one of the factors that shape the way people view disasters and find space to respond and recover (Bradshaw 2013; Cupples, 2007; Enarson and Morrow, 1998; Irshad, Mumtaz, and Levay, 2012). Disasters are the outcome of a natural hazard and people's exposure and vulnerabilities. Vulnerability to disasters is a complex outcome of historical power relations, economic differentiation and other social processes. Gender is one of the determinants - often working through other determinants as well - in creating vulnerability (Bankoff and Hilhorst, 2004; Bradshaw, 2001; Irshad et al., 2012).

There is a growing body of literature analysing disaster through women's eyes, starting with the analysis of vulnerability in relation to its roots in gender inequality (Bradshaw, 2014; Horton 2012) to studies on how women fare in the aftermath of disaster - mobilising their networks and playing multiple roles in the time of crisis and beyond (Perera-mubarak 2013; Ruwanpura and Humphrie 2004). This article contributes to this body of literature by providing the story of the Nepal earthquake through women's eyes.

Other studies concerning women in the aftermath of earthquake in Nepal include Sthapit (2015) on the impact of the earthquake and Standing et al. (2016) on violence against women and girls (VAWG). There have also been reports providing both qualitative and quantitative documentation of post-earthquake Nepal (Inter-Cluster Gender Task Force, 2015; Save the Children, 2016).

This article stands out because of its real-time ethnographic approach and because it followed the same group of women for several weeks. As a result, our narrative is comprehensive and brings out some issues that have until now received little attention in debates on gender and disaster. One such issue is the importance of documents in the aftermath of disaster. Many problems that women encountered were related to not having the right official papers. The article can also be seen as an ethnography of the gendered bureaucracy surrounding disaster.

The first section of the article reviews literature on gender inequality and disaster, and is followed by a section introducing gender issues and inequality in Nepal. The findings sections are organised according to three phases of disaster: evacuation, relief and recovery, and the concerns voiced by women, in particular, on issues of identity papers and debt. 


\subsection{Conceptualising Gender Equality and Disasters}

Disasters triggered by natural hazards are largely social phenomena. This starts with the hazards, because in this anthropocene era natural hazards, especially hydro-meteorological hazards, are increasingly affected by the outcomes of human activity, such as deforestation and climate change. Natural hazards only result in disaster when they meet vulnerable conditions and populations. Social processes generate unequal exposure to risk by making some people more prone to disaster than others and these inequalities are largely a function of the power relations existing in every society. The determination of vulnerability is itself a 'complex characteristic produced by a combination of factors derived especially (but not entirely) from class, gender and ethnicity' (Bankoff and Hilhorst, 2004; Cannon 1994).

Nonetheless, attempts to engender disasters are decades behind the similar process of engendering development (Bradshaw 2013, p.58). Until the 1990s, issues related to gender did not receive priority in disaster response and it is only recently that gender specific aspects of women's and girls' experiences have made it on to the humanitarian agenda (Standing et al. 2016). In 1998, the book Gendered Terrain of Disasters by Enarson and Morrow appeared. In 1999, the International Journal of Mass Emergencies and Disasters of the International Sociological Association published its first special edition dedicated to women and disasters (Bradshaw 2013, p.58), calling on scholars, academics and policy makers to investigate gender dimensions in disaster and post-disaster.

There is now a growing amount of evidence on the specific challenges' women encounter during disasters. Women and girls were systematically disadvantaged by food relief in the aftermath of the 1991 Bangladesh cyclone (Fothergrill, 1998). In Nicaragua, post-Mitch threequarters of the people reported as emotionally affected by the hurricane were women and girls (Bradshaw 2001, p.80). When Hurricane Katrina occurred in 2005, low-income African American women were most vulnerable in New Orleans at the various stages of evacuation, relief, and reconstruction (Pardee 2014). In post-earthquake Haiti, large numbers of women and girls suffered from sexual abuse and post-traumatic stress disorder (Horton 2012; Rahill, Joshi, and Hernandez 2016). The hostile judicial process reinforced the social stigma and intimidation of the victims of sexual and gender-based violence (Horton 2012, p.300). 
Two findings consistently run through the literature. The first is that pre-disaster gender inequalities and practices lead to gender-specific shortcomings during disasters and afterwards (Pardee 2014; Irshad et al. 2012; Horton 2012). Secondly, in the words of Fothergill (1998, p.23), the 'neglect of gender in non-disaster periods could reproduce gender-related vulnerability during disasters.

If gender is recognised as one of the factors producing vulnerability to disasters, it is not enough to focus on women's differential experience of disaster and their specific needs in the aftermath. As Fothergill points out, feminist theories are helpful 'tools for understanding the links between women's lived experience and the structure of social inequality' (Fothergill 1998, p.24). Bradshaw likewise argues that 'it is important to remember that the study of gender is not then the study of women, but rather the study of (unequal) relationships between men and women, why and how they are produced and reproduced and how they can be changed' (Bradshaw 2014, p.42). She continues her argument that 'to recognize these differences or to work to change them is usually what is meant by the notion of taking a 'gender perspective'. Her argument is sometimes also presented as analysing an issue through a 'gender lens' (ibid). In this way, this article aims to bring a gender perspective to the Nepal earthquake.

Arguments about gender in disaster have been further nuanced in two ways. First, there has been attention to broadening the scope of the gender perspective by bringing in issues related to masculinity and acknowledging cultural differences between men and women (Luft, 2016; Morioka, 2014) in the extent to which men and women are binary opposites. The gender perspective has also been broadened by focusing on other gender categories, including LGBT genders and their specific issues during disaster (Gaillard et al. 2017; Dominey-Howes et al. 2014). Secondly, some authors have focused on the diversity among women and the importance of intersectionality, demonstrating how gender interrelates with class, ethnicity, and other social identity markers (Ruwanpura and Humphries 2004; Pardee 2014).

Gender as a system of power relations, like everything else, is cast into disarray during large disasters or other humanitarian crises. The ways in which gender relations continue, discontinue, alter, or bounce back before, during, and after crises are complex and dynamic (Hilhorst, Porter, and Gordon 2018, p.9). There have been cases where disasters are seen to trigger changes in gender relations. Perera-Mubarak (2013) in Sri Lanka found how in the aftermath of the tsunami of 2004, some women challenged their stereotypical roles and became 
financially independent by running their own business without male support. Even though disaster can bring about change, it needs to be acknowledged that gender has different layers with different paces and dynamics of change. It is important to monitor whether, and in what way, improvements in daily gender relationships lead to longer-term or more fundamental changes (Hopwood, Porter, and Saum, 2018; Horton, 2012).

\subsection{Gender Equality and Inequality in Nepal}

This section details some factors that constitute gender equality and inequality in Nepal. These are important to highlight because women's experience in the earthquake intersects with these factors and they shape and reshape their diverse experiences in the crisis.

Inequality based on caste, gender and ethnicity is deeply embedded in Nepalese society (Acharya, 2007; Regmi, 2007). A woman's position is contingent on her father, husband or other male head of the family (Parvati 2003). This is enshrined in Nepalese inheritance systems, family relations, patrilocal residence, and patriarchal descent, and reinforced by legal system (Dhungana 2014). These factors exist at the level of family and in the community. They produce inequality and women may face specific vulnerabilities because of gender, social position, caste and class. Inequalities exist in people's mind-sets (both women and men) and have often been internalised. People are socialised according to patriarchal values that are manifest in everyday life (Bennett 2005) even at times of disaster and crisis.

However, recently there have been some transformations in Nepal. Changes in the law after the Comprehensive Peace Agreement, which ended Nepal's decade-long political conflict in 2006, committed the parties to restructuring the state based on inclusiveness, democracy and progression (CPA 2006). The signs of improvements that are apparent in the law, in the official representation of women in politics, may be insubstantial when examined more closely. For example, the recent 2015 Constitution reserved 33 percent quota of parliamentary seats for women. Political parties often push women candidates into quota seats with little or no power, which then prevents women from running for direct electoral seats (Saif and Alia 2017). For example, in the recent 2017 constitution assembly election, only six women won direct election out of the 165 first-past-the-post (FPTP) seats (ibid). Similarly, research by K.C., Van der Haar and Hilhorst (2017) found that while Maoist women ex-combatants in Nepal experienced a marked shift in gender roles during the war, with women taking on tasks earlier reserved for 
men, in the post-conflict era such changes were not maintained, and they faced severe livelihood challenges and returned to traditional gender roles. These findings underscore the complex nature of change of gender roles during and beyond crisis.

For many decades, Nepal's citizenship law has discriminated against women. Under current citizenship laws, women can only obtain citizenship under their father's or husband's name. Even though the new law proposes citizenship by descent - that is, passed by either the mother or the father to the child - the methodology is vague. This produces further inequalities and regressive tendencies towards women (Pant and Standing 2011, p.412). For example, Nepali women and their children need to be born in Nepal to obtain citizenship by descent, whereas this is not applied to the children of Nepali men (see Constitution of Nepal 2015; Article 10, p.11). Citizenship certificates are vital for claiming rights and getting access to formal services in Nepal including marriage registration, property, taxation, foreign employment, education, and the opening of a bank-account, etc. A study by Care Nepal (2016) found that $20 \%$ of the population does not have a citizenship certificate. These are mainly people from the Dalit (untouchable caste) population and indigenous groups, especially women.

Despite some advances in the current Constitution of 2015, legal differences continue. Article 38.6 of the constitution states that 'both the spouses shall have equal rights in property and family affairs.' Considerable challenges nevertheless remain in the implementation of these provisions on the ground (Malla, 2015), because for centuries Nepalese society has been structured on a patrimonial property inheritance system. Although the constitution forbids gender discrimination in inheritance, it remains to be seen if daughters will claim their share of property, currently or retrospectively, and how this will be translated into inheritance practice at the family level. Feminist activists and advocates have argued that the property rights provision is unclear and confusing, leaving too many loopholes that can prevent daughters from claiming property on an equal footing with their brothers (ibid). A study by Care Nepal (2016) points out that women in Nepal own only 19.17 percent of total land and property.

Many other social indicators are negative for women. Only 15 to 20 percent of girls who attend primary school go on to the secondary level in Nepal and the female literacy rate is 57.4 percent compared to the male rate of 75.1 percent (Central Bureau of Statistics, 2011). Forty-one percent of Nepalese women aged 20-24 years in 2015 were married before they turned 18 
(UNFPA 2014). In marriage, women's destiny and livelihood options largely depend on her husband and parents-in-law (Parvati 2003). Traditional gender norms usually confine women to the private domain of the kitchen, household, farm and family, whereas men largely occupy the public sphere of jobs, market, and formal economic activities (K.C., Van der Haar and Hilhorst 2017).

\subsection{Research Site and Methodology}

This study is focused on local women and migrant women living in Bungmati village. The area was primarily chosen because it is the first author's neighbourhood village. It is just $6 \mathrm{~km}$ from her house and she has many memories and emotional connections with the people and the place itself. She also had the advantage that she already knew some women in this village prior to the earthquake. Bungmati lies in Karyabinayak Municipality in Lalitpur District of Nepal. Newar ${ }^{19}$ is the dominant ethnic group. It is a rural village and household economies predominantly centre on farming and livestock. Outside of farming, men mostly engage in wood carving. Women are mainly engaged in household chores, farming, livestock rearing and share-cropping. In terms of social-economic status the participants all came from poor family backgrounds (though their caste is different) with their husbands as primary bread-winners.

The article is based on the stories of 22 women earthquake survivors: 13 participants were local women from Bungmati area. Interviews were held between May to September 2015, capturing five months of the lived experience of these 22 women, and how these relate to structures of social inequality (c.f. Fothergill 1998, p.24). They had little education and none of them had ever participated in development activities by NGOs. Nine were migrant women from other districts in Nepal that were living in a rented house. All the women in the study were displaced and living in a shelter when the research started. The earthquake caused grave personal loss. One participant lost her husband and father in-law, three women were injured, and two women had particularly traumatic experiences because their children were locked inside and could only be rescued by neighbours and the police after 6 to 8 hours.

The first author of the paper got to know these women when she first started visiting the area. A few days after the earthquake, she made a first visit to Bungmati, where women and children

\footnotetext{
${ }^{19}$ An ethnic group of Nepal, having their own language Newari.
} 
were living under plastic shelters, with very little access to food and water. Among her first impressions were the children crying of thirst and hunger amidst the debris of the earthquake (fieldnotes 29 April 2015). During the first visit, she also talked to some school teachers, who shared information about the death toll and damage in the area, and the complete absence of any form of relief up to that time.

The interviews were mainly informal and conversational. Women who have just survived an earthquake cannot be confronted with a list of closed questions. Instead, the interviews took the form of storytelling, where women were encouraged to talk about what happened and how they felt. Initially, stories were exchanged about what happened during the quake and how they came to be rescued. Gradually, the conversations shifted to the relief assistance they received from government, NGOs or family and friends, as well as their lives before the earthquake and the losses they had experienced. In the weeks thereafter, conversations moved to the question of the recovery of their livelihoods. Interviews could take many different directions, focusing on how the participants experienced the earthquake and post-earthquake, their roles and responsibilities in the process, and their responses towards evacuation, relief, recovery and beyond. A focus was maintained on women's experience and agency, following Cupples (2007, p.170) who stated the importance of relating 'how women feel about and reflect on the spatial realignments resulting from disaster events or processes and on the ways in which they constrain and facilitate, rather than concentrate exclusively on what a disaster does to women'.

During visits and interviews, only a few notes were made. Most notetaking happened immediately after the interviews, first in Nepali and later translated in English. Atlas ti. (qualitative data analysis software) was used to analyse the data, developing codes in the process as the material grew, topics came back, and patterns evolved. In the following sections, findings will be presented. All interviews were held in Bungmati, and we added the month of the interview to show when the statement was made. 


\subsection{Women's Stories of the Earthquake}

A rapid onset disaster like an earthquake means a total disruption of everything that occupied the people and for a considerable time the rhythm of their lives is completely dictated by the processes of evacuation, displacement, relief and recovery. Starting with evacuation, this section follows the earthquake through the eyes of the women.

Sunita Mali was in the house when earthquake happened and risked her own life while saving her family:

When the earthquake happened, I did not know what was going on. I never imagined what an earthquake would be like. I suddenly felt the shake and heard everyone screaming. I first thought of my family. I first rescued my husband, who is physically very weak because his kidneys don't function. Then I carried my mother in-law of 86 years old downstairs. When I wanted to escape myself, I could see the roof of the house falling towards me, and it cracked down on my head. I don't recollect what happened after that, but my husband told me that I was rescued from the house after 9 hours, with the help of neighbours, and brought to the hospital. (September).

Sunita who is responsible for the family, found it natural that she did not run but took care of her family when the earthquake happened. Like so many other women, and so many of them have household members that are particularly vulnerable and cannot run, due to age or disability. Uma Thapa was pregnant when the quake happened:

I was alone at the $2^{\text {nd }}$ story of the house at the moment that the earthquake hit, my husband was away to another district. It was difficult to run, I was 7 months pregnant. I screamed for help, it was very scary, but I cannot run with my big stomach from the $2^{\text {nd }}$ floor. I slowly managed to go near the window, and then my neighbour saw me. He and another neighbour rescued me. By that time, I was knocked-down. I cannot sleep properly until today. I can't believe that I am still alive. I don't know if this will impact my baby. (May).

Sunita and Uma's experiences of the quake were related to their roles of wife and mother. The stories of the women also give hints to their social roles and positions. Uma's sense of helplessness was related to her pregnancy, but also to the fact that her husband was away. 
One of the most moving stories was told by Sanu who lost her husband and father-in-law in the earthquake. It is a story of powerlessness in the face of disaster and helplessness to save her loved ones.

On the day of the earthquake it was Saturday. I ate my morning meal together with my whole family and went to the farm after finishing my household chores. The last thing I remember before leaving the house were my husband and father in-law watching TV. As soon as the earthquake hit, I returned, and I saw my house collapsed...my husband and father in-law were locked inside. I became like a paralyzed person. I screamed loud for help, but the earthquake's storm was so loud that nobody could hear my voice. Everyone in my neighbourhood was trying to save themselves. My son went to city centre on that day and he was not around with me. I was worried for him, but he was safe. I wish I had a mobile phone, and know how to use it, so I can call someone for help. But I cannot read and write. Every time I regret, I could not save my husband and father-in-law. (May).

The story of Sanu and her regret that she did not know what to do or have the means to ask for help, give a window into the way gender relations operate in everyday life. Her illiteracy and lack of confidence to handle a mobile phone were related to, but also compensated in her normal life, by the fact that the man in the house would deal with communication to the outside world. When the earthquake hit, it made her feel utterly helpless. Not used to making on-thespot decisions, she felt she had little choice but to wait and hope for her son to return. Bereft of her loved ones and her house, she has to face the recovery of her life while struggling with the huge challenges of grief, remorse and widowhood.

Even evacuation is gendered. At the spur of the moment, women act on the power of their motherhood but also acutely experience the limitations that have grown out of their social roles. Even though the quake happens in an instant, women bring their gendered dispositions grown over a lifetime to the occasion.

\subsection{Lived Experiences of Displacement}

This section provides testimony on women's experience of displacement and their coping mechanisms for surviving in the temporary camps. 
In the first months after the earthquake, women stayed with their relatives in temporary camps. After four months of living in a tent, Shova, a young mother in her late twenties whose house completely collapsed, narrated how she had embarked on an exhausting routine.

I work more now than before the earthquake. Finding a place to cook and to fetch water is difficult in a new place. I now walk 40 minutes to bring water to cook and drink, and the same distance to wash clothes. My daughter is only 6 years old. I always take her along. I have to be more careful, because my daughter does not know this place as well as she knew our house. I am scared she might get lost and people don't know her so well. The extra caring and household tasks is a big problem. My husband does not help me, he always goes out with his friends. He has no work since the earthquake, because the wood carving shop that employed him collapsed as well. He doesn't help me and only comes to the camp when the food is ready. We survive because my mother and brother gave us utensils, blankets, some money and food. We also borrowed money from our relatives. I am looking for work, any type of work like maid or daily labour. I have no choice but to take the responsibility. (August).

The story of Shova and her husband was quite general. For women, their responsibilities of care continue at a more complicated level in the context of displacement. Their husbands, on the other hand, have less continuity in their responsibilities, with much employment halted after the earthquake. Nonetheless, they maintained the pre-established gender division of labour.

Nitu, a breast-feeding mother shared how she managed displacement in the first weeks after the quake, together with her daughter, in the absence of her husband:

Due to the earthquake the water taps in my area broke, now I walk around 30 minutes daily to fetch water for cooking, and to wash my clothes. My husband is stuck somewhere else due to the earthquake, as the roads are blocked in our village. I have a 6-month old daughter, so I must carry her along with the heavy clothes and water jar. Living in a temporary camp with a small child is tough. My daughter keeps crying in the night, and then I must change her diaper and feed her quickly, because some people don't like the noise of children. (May). 
Nitu, like Shova, is solely responsible for caring for a child in the household, in her case because of the absence of her husband who is stuck in a distant village. For marginalised women, the situation was even more precarious. A migrant woman, Kiran, shared her story of displacement:

My husband went for foreign employment to Saudi Arabia, and I am alone with my 8-year old son. I lived in a rented house, that collapsed in the earthquake. So, I had no place anymore to live. My husband's brother who is in the village does not talk to me because of my caste. I am Tharu (indigenous group) and my husband is Chettri (upper caste). For the first 6 weeks I made a tent of bedsheets. But nobody knows me here. After six weeks, the landowner asked me to move from his land. Now I am living in another temporary tent, and I don't know what will happen next. Maybe I can stay here or maybe I have to move to another place. (July).

Kiran's migrant identity created social isolation, made complete by the absence of her husband and disregard of her husband's family. Her narrative demonstrates the working of intersectionality, where gender intersects with caste and her history with migration (Rampurawa and Humpuries 2004; Perara-Mubarak 2013). While women tried to cope with their displacement in the first months after the earthquake, two themes recurred often in their stories: a sense of insecurity, and the issue of psychological stress.

\subsubsection{Insecurity During Displacement}

Issues of insecurity in the temporary shelters frequently figured in the stories of the women. The women lived in tents made from plastic or cloth, and without a door or window anybody could get access. Sheltering in open camps created threats during the night, when strangers could enter the sites. Several women told about groups of people around their camps that consumed excessive alcohol, used abusive language or engaged in gang-fighting, leaving the empty bottles around the camp. Sarawati shared the following incident:

One evening, a group of strange boys entered the camp, when they notice there are only women and small children. I and other women started to shout out loud, until the boys ran away. (May).

Apart from their personal security, women especially feared theft. They found some security, however, in the presence of other women - and men - that were close by, so they could deal with intruders. 


\subsubsection{Psychological Stress}

Women, unsurprisingly, often talked about the psychological duress they felt from the quake, their losses, the challenges of displacement and their worries about the future.

Ganga, a migrant mother of three children shared her story:

My son (6 years old), broke his hand when he was locked inside the house and my other two kids were also heavily injured on their legs and body. My children are traumatised. I lost everything in the earthquake, so now I must buy many things that I lost but I don't have income and my husband also lost his job. I have to pay rent. My relatives are also very poor and face the same situation like me. I am always worried (September).

Sanu shared her emotional stress from the earthquake as follows:

After my husband and father-in law died in the earthquake, it I did not sleep for two months. I see horrible dreams, until now I did not dare to go inside my house, it feels like a graveyard. I just left my belongings there and will never use them anymore. It will give me pain to see them and remember my loved ones. (August).

Bimala described her situation thus:

The earthquake made me weaker and weaker, day by day. I was admitted in the hospital for 10 days and went through head surgery. Now I cannot work like before. I am also worried how to reconstruct the house and pay our debt. My parents are also poor and cannot help me (September).

The emotional effects related to the accumulation of issues, starting with the loss of the people in the traumatic event of the earthquake. Save the Children (2016) found that a high number of women and girls in Nepal developed post-traumatic syndrome (PTSD) during the earthquake. The stories of the participants in this research reveal that the source of their trauma continues well into the aftermath of the disaster. These are the worries of displacement, as well as - as we shall discuss below - the challenges of recovery and especially their outstanding debts. 


\subsection{Role of Citizenship and Land Entitlement Documents in Accessing Relief}

As the stories above reveal, women could only rely on their neighbours and relatives in the first weeks after the disaster. There was no official relief from government or aid agencies. After several weeks, relief programs started to get shape. However, as it turned out many women encountered legal impediments to have access to these programs.

Many women encountered challenges in obtaining relief goods because they did not have a citizenship certificate. Fulmaya, a migrant woman, told her story two months after the earthquake:

My husband is out of the country as migrant worker. The house I used to rent was destroyed and all my personal belongings are buried inside the house. The mattress, radio, stove, everything. Until now, I did not receive relief goods or cash compensation from the government. Every time I go to the local office of the relief service, they ask me to show citizenship certificate or land ownership certificate or my marriage certificate, but I don't have these papers. My parents did not register my birth in the village, so don't have a birth certificate. I also don't have a citizenship certificate and therefore I was not able to register my marriage. Without these papers, I cannot open a bank account in my name. Before the earthquake, my husband would send money to my brother-in law who lives in another district, and then he will give me my share. But my brother in-law's house also collapsed, and he is injured. The roads are blocked, so I cannot go to visit him to get money. For several days after the earthquake, my son and I had hardly anything to eat. After that, I borrowed money from my neighbours. I also bought food from the grocery store on credit, as this store person knows my husband, so he trusts that we will pay him back in the end. (June).

Fulmaya's story shows the importance of appropriate papers to obtain relief. Until the earthquake, her life was more or less organised despite this lack of papers, and it is only when the disaster happened that her immense vulnerability showed, as well her complete dependence on the accessibility of her in-laws who lived far from her. Sanu, who lost her husband in the earthquake, further confirmed how dependence on relatives may work against women:

Whenever I went to collect relief items in the local office, they informed me that my brother-inlaw already collected my relief goods. That was without my permission, and I never received the goods from him that he collected in my name. The distribution authority assumed that because I am his sister-in law, he will deliver goods to me. When I found out, I told my son and then he 
started asking his friends when relief distribution was coming. And he started going to the relief office. My son has his birth certificate issued in Bungmati, so he could convince officials about his local residency. I also borrowed money from my relatives to fulfil my family needs. Normally the relief was not sufficient to fulfil all our basic demands. The relief goods distributed at that time were: soaps, medicine, sometimes rice or beans or few times cooking oils, or milk. After few weeks my brother found a part-time job for my son and we could repay some of the debts which we took from the grocery shop in the of emergency. (September).

The fact that Sanu's brother-in-law can collect her relief goods without her permission is a disgrace, but entirely possible in the patriarchal organisation of society, where men are supposed to assume the communication with the outside world including authorities. The relief office maintained an operational rule that relief was only going to be provided to people upon show of identity documents such as citizenship certificates or land entitlement certificates. Even though this rule made sense in the techno-logistical mode of relief operations, it led to discrimination against women. The stories of Fulmaya and Sanu illustrate how this works. In both the stories, the release officers were not prepared to listen to the women and help them. In the first case, they simply insisted on her showing papers she did not have, and in the second case the relief office was deaf to the claim that the relief goods were confiscated by her brotherin-law.

Mira adds to the stories and relates how she was excluded from cash compensation for households of earthquake victims, even though she has a husband:

I was not able to receive Rs. 15,000 (an estimated US \$ 150) cash compensation received from the government as a maintenance cost, because the land entitlement document was in my husband's name. My husband collected the money and he spent it as he wished. He did not think about the family.

Many women stated that getting relief was easier for men. Men usually had citizenship papers. In addition, they would find it easier to be heard by relief workers who tended to accept the narratives of men, rather than of women. Participants in the research also mentioned that households with a high social status and good links with political parties and aid workers, were pre-informed about timing of distributions of relief services and were able to easily get their hands-on relief. Migrant families, on the other hand, were often excluded because they were considered temporary, even though they had lost many personal belongings. 


\subsection{Livelihood Distress Beyond the Relief Phase}

After some months where women mainly relied on relief, they had to get ready to resume their livelihoods. This section details some of the challenges the women participating in this research encountered. Most of the women that participated in this research lost all their belongings in the earthquake. In many cases these were not only their household belongings, but they had their livelihood assets stored in their houses. While these got lost, outstanding debts remained.

This is the story of Maya:

When my house collapsed, my chickens and ducks also died. With the house, I lost stored food for 2 months (oil, butter, beans), and my store of grains and rice that were supposed to last us for a year. My cooking utensils, clothes, table, chair, TV, and other assets were all buried and damaged. The stored grain inside the house, got rotten and muddy and could not be used anymore. But we must still pay the debt with interest to the landlord that we took last year for farming. Even though I lost my harvest and income in the earthquake, I am still paying back the loan. Now, we stay in a rented house. Before the earthquake, my husband had just sold a piece of land to do some business; and we are now surviving with that money, including paying debt, rent, and all our other costs. (September).

When Maya lost the stored grain, she lost a major part of her investment and savings, while her costs increased because she now rents a house. In view of these losses, she had no choice but to add new debts parallel to her old debt.

Maiya told a similar story:

Last year, we took Rs. 50,000 (\$500) for my farming (labour, equipment, fertilizers) and irrigation from the local landlord, but now I lost all my grains and seeds in the earthquake. Everything is gone but I still must pay the landlord's debt with interest. I don't know how I am going to pay it. At some point, we are planning to sell our land. After the earthquake, my sister helped with some cash, food and clothes. Other relatives supported us with finding a place to live. My cousins are helping to find a job for my husband. (September).

Shiva Mali and her husband relied on share-cropping. Unfortunately, the land that they used to lease was no longer available after the earthquake, because the landowner could lease the 
farmlands more profitably to housing companies who were constructing rental houses for families displaced by the earthquake. While this took Shiva's family's means of production away, they managed through temporary jobs that stemmed from the disaster. Shiva's husband got a part-time job in a housing construction company as a carpenter, and Shiva started working as a debris cleaner on a daily basis.

Women only had very few options for their livelihoods. Their usual occupation in farming dwindled, because land availability was reduced after the earthquake. Their lack of education and experience further limited their options to find alternative livelihoods. Again, bureaucratic discrimination added to these problems. Samjhana talked about her attempt to obtain a loan:

The earthquake took everything. I then wanted to resume my small business of selling vegetables and fruits. But I was not able to acquire even a small loan from the bank because my husband is out of the country. They think I cannot repay the loan in the absence of my husband, despite having all the required loan documents. (July).

All in all, family still was the major support in recovery, as Kusum Dongol explained:

My brother in-law who lives in Kathmandu valley has arranged a new job for my husband, therefore even though his old job collapsed we are able to survive with his current job. My brother also provided us shelter in their house for almost 3 weeks after the earthquake, gave me food, shelter, cupboard, mattress and many things that I need. (September).

For many women, their family support was limited, because relatives were also poor or disadvantaged by the earthquakes, while a number of migrant families had no relatives in the area. According to the participants of the research, the situation for men was different. Many men also lost their livelihood in the earthquake, but they found it easier to find a new job. There was a high demand for male labour in the reconstruction, and they had a better understanding of the labour markets, better education and skills. They also had networks and resources to access jobs. 


\subsection{Changing Gender Roles and Relationships After the Earthquake}

The many hardships faced by women underlined how ill-prepared their traditional roles made them for coping with the crisis. Nonetheless, women found that they were taking up new roles and responsibilities, and that could fill them with pride.

After the earthquake, gender norms became more fluid. For example, girls and women during their menstruation were allowed to stay together in the camps, and to touch food, cook meals, and collect water, against the normal cultural expectations of seclusion during menstrual periods. Women are normally prohibited to go to the $\mathrm{Ghat}^{20}$ to attend funerals, but after the earthquake, women participated with men in conducting funeral rituals.

Forced by the circumstances, some women had to step forward and started finding jobs for themselves. A few of them started working as part-time labourer: removing village debris, painting walls and ceilings for organizations building temporary houses in their area. Especially widows were transformed into breadwinners after their husband's death. Sanu shared her story:

When my husband was alive, I did not have to worry for anything, but now I am doing everything. Now, I work as a painter. My first job in my life and my first earning. To feed myself and my family, I have to do it. (July).

It was noticeable, that women also started to talk about their personal issues. When revisiting women several weeks after the earthquake, many expressed an interest to participate in empowerment trainings, and income generation programmes. Some women were eager to start adult literacy classes.

This change in attitude was related to their feelings of helplessness and inadequacy during the earthquake. It was also facilitated because women in temporary shelters got a chance to interact with other women of different backgrounds. Caste-based discrimination and social distances disappeared (temporarily) into the background, exposing poor and marginalised women to other views. Women of all backgrounds shared the same worries, information, goods and services in the camps. Coping with the situation gave some women also new confidence in

\footnotetext{
${ }^{20}$ Place where bodies are set on fire, normally at the river bank.
} 
their skills. The period of interviews was too brief to assess how lasting these changes would be.

\subsection{Conclusions}

This paper followed 22 women who survived the earthquake in Nepal and found themselves living under plastic shelters for many weeks while trying to take care of their family and trying to reorganise their lives. It brings out many experiences that accumulate in extremely stressful and highly insecure conditions. All the participants of the study were of poor backgrounds, but their experiences were different, especially with regards to the intersectionality of gender and migration and family composition.

While one of the women lost her husband in the earthquake, it is striking how many of the women found themselves separated from their husbands in the aftermath of the disaster. Their husbands were sometimes quite close by but could not return due to blockages of roads, or they had migrated abroad. Some women who had their husband with them, nevertheless had to take the main responsibility for caring, and all of them felt that their workloads were much heavier during displacement than before.

Previous research on gender and disaster consistently found that pre-disaster gender inequalities and practices led to gender-specific problems in the time of disaster and afterwards (Pardee 2014; Irshad et al. 2012; Horton 2012). That was also the case in Nepal. At the very moment of the earthquake, many women instantly jumped in to rescue their vulnerable family members, but nonetheless some women told how they felt inadequate and indecisive in dealing with the rescue. The rather strict traditional gender division wherein women's domain is in and around the house while men take care of the outer world, led to many obstacles for women in the aftermath of the disaster.

The displacement after the earthquake, with many families living under nothing more than a plastic sheet to protect them from torrential rain, and all the visible losses and injuries created many dramatic and traumatic problems. Underneath these highly visible problems, we found layers of less visible problems that women found especially daunting. 
One such issue concerned debts. Many families were facing debts from before the disaster, with interest continuing, and often had to take additional loans to survive. Worries about debt added considerably to the psychological duress of women. With the collapse of their houses, often the means of livelihoods and stocks of food reserves also disappeared, making it even more difficult to organise the household finances. While many men, and some women, could easily find temporary day-jobs in the rebuilding of houses, the erosion of their economic resilience, loss of assets, land entitlements and jobs, will be felt for years.

The other issue concerned legal impediments. Even though Nepal has a brand-new constitution that declares gender equality, the law continues to differentiate between men and women, sometimes in the text of the law but more often in its application. In particular, women rely on their husbands or fathers to obtain civilian certificates. An estimated $20 \%$ of the population has no identification papers (Care Nepal 2016) and that was also the case for 9 of our 22 research participants. These problems hindered access to relief and compensation, which was made worse by the inexperience of women in dealing with the bureaucracy, and the tendency of bureaucrats not to listen to women's stories or take the stories seriously.

The earthquake turned out to be a magnifying glass that unveiled the enormous dissonance between the slow pace of change in traditional gender relations and the ongoing changes in Nepalese society, especially in relation to migration. The traditional ways presuppose that women can lean on the protection of their husbands and close kin, but in reality, as the postearthquake realities made painfully clear, many women find they have responsibilities that cannot be handled without citizenship certificates, mobile phones or confidence and skills to seek employment out of the house.

Finally, we found that despite emotional stress, pain and trauma, women started to revisit their roles in the aftermath of the disaster. Gender norms became more fluid and there is a tendency to take on new roles previously associated with men. Significantly, a number of women became very conscious of the limitations of their usual roles and developed ambitions to change, partly instigated by the interaction with other displaced women of different backgrounds. Literature on gender and disaster does not make us very optimistic about the likelihood that these changes will be lasting, but this is a matter for future research as conversations with the women this paper ended five months after the disaster. 


\subsection{References}

Acharya, M. (2007). Issues of Women's Empowerment and the Future Constitution. Kathmandu Nepal.

Artur, L. (2011). Communities in Crisis: everday peactices of disaster response and climate adaption in Mozambique. Wageningen University.

Bankoff, G., \& Hilhorst, D. (2004). "Mapping Vulnerability.” In G. Bankoff, G. Frerks, \& D. Hilhorst (Eds.), Mapping Vulnerability: Disasters, Development \& People (pp. 1-10). London: Earthscan.

Bennett, L. (2005). Gender, Caste and Ethnic Exclusion in Nepal: Following the policy process from analysis to action. New Frontiers of Social Policy, 1-48.

Bradshaw, S. (2001). Reconstructing Roles and Relations: Women's Participation in Reconstruction in Post-Mitch Nicaragua. Gender \& Development, 9(3), 79-87. https://doi.org/10.1080/00223891.2011.608754

Bradshaw, S. (2013). Gender, Development and Disasters. UK: Edward Elgar.

Bradshaw, S. (2014). Engendering development and disasters. Disasters, 39, 54-75.

Cannon, T. (1994). Vulnerability Analysis and the Explanation of 'Natural' Disasters. In A. Varley (Ed.), Disasters, Development and Environment. (pp. 13-29). New York, Brisbane, Trornto and Sigapore: John Wiley \& Sons.

Central Bureau of Statistics. (2011). Population Profile of Nepal. Kathmandu. Retrieved from http://cbs.gov.np/sectoral_statistics/population/population_profile

Constitution of Nepal. The Constitution of Nepal 2015, Nepal Goverment (2015). Kathmandu: Ministry of Law, Justice and Paliament Affairs.

CPA. Comprehensive Peace Accord (2006). Kathmandu Nepal: Government of Nepal.

Cupples, J. (2007). Gender and Hurricane Mitch: Reconstructing subjectivities after disaster. Disasters, 31(2), 155-175. https://doi.org/10.1111/j.1467-

7717.2007.01002.x

Dhungana, R. K. (2014). Nepali Hindu Women's Thorny Path to Liberation, School of Education, Kathmandu University, Lalitpur, Nepal. Journal of Education and Research, 4(1), 39-57. https://doi.org/: http://dx.doi.org/10.3126/jer.v4i1.10013

Dominey-Howes, D., Gorman-Murray, A., \& McKinnon, S. (2014). Queering disasters: on the need to account for LGBTI experiences in natural disaster contexts. Gender, Place \& Culture, 21(7), 905-918. https://doi.org/10.1080/0966369X.2013.802673

Enarson, E., \& Morrow, B. H. (1998). Why Gender? Why Women? An Introduction to Women 
and Disaser. In E. Enarson \& B. H. Morrow (Eds.), The Gendered Terrain of Disaster (pp. 1-9). London: Praeger.

Fothergrill, A. (1998). The Neglect of Gender in Disaster Work: A Overview of the Literature. In E. Enarson \& B. H. Morrow (Eds.), The Gendered Terrain of Disaster: through women's eyes (pp. 11-25). London: Praeger.

Gaillard, J. C., Sanz, K., Balgos, B. C., Dalisay, S. N. M., Gorman-Murray, A., Smith, F., \& Toelupe, V. (2017). Beyond men and women: a critical perspective on gender and disaster. Disasters, 41(3), 429-447. https://doi.org/10.1111/disa.12209

Hilhorst, D., Porter, H., \& Gordon, R. (2018). Gender, sexuality, and violence in humanitarian crises. Disasters, 42, S3-S16. https://doi.org/10.1111/disa.12276

Hopwood, J., Porter, H., \& Saum, N. (2018). Resilient patriarchy: public authority and women's (in)security in Karamoja, Uganda. Disasters, 42, S140-S158. https://doi.org/10.1111/disa.12272

Horton, L. (2012). After the earthquake: gender inequality and transformation in post-disaster Haiti. Gender \& Development, 20(2), 295-308.

https://doi.org/10.1080/13552074.2012.693284

Inter-Cluster Gender Task Force. (2015). Gender Equality Response to the Nepal Earthquack (Vol. 16). Kathmandu.

Irshad, H., Mumtaz, Z., \& Levay, A. (2012). Long-term gendered consequences of permanent disabilities caused by the 2005 Pakistan earthquake. Disasters, 36(3), 452-464. https://doi.org/10.1111/j.1467-7717.2011.01265.x

K.C., L., Van Der Haar, G., \& Hilhorst, D. (2017). Changing Gender Role: Women's Livelihoods, Conflict and Post-conflict Security in Nepal. Journal of Asian Security and International Affairs, 4(2), 175-195. https://doi.org/10.1177/2347797017710743

Luft, R. E. (2016). Men and Masculinites in the Social Movement for Just Reconstruction After Hurricane Katrina. In E. Enarson \& B. Pease (Eds.), Men, Masculinities and Disaster (pp. 34-44). London: Routledge.

Malla, S. (2015, September 21). Citizenship proivsions discriminate agaist women: Nepal Constitution 2015. The Himalayan Times, p. 1. Kathmandu. Retrieved from https://thehimalayantimes.com/nepal/citizenship-provisions-discriminate-against-women/

Morioka, R. (2014). Gender difference in the health risk perception of radiation from Fukushima in Japan: The role of hegemonic masculinity. Social Science and Medicine, 107, 105-112. https://doi.org/10.1016/j.socscimed.2014.02.014 
Nepal, G. of. (2015). Nepal Earthquack 2015 Post Disaster Needs Assessment (Vol. A). Kathmandu.

Pardee, J. W. (2014). Surviving Katrina. London: FIRSTFORUMPRESS.

Parvati, C. (2003). Women's Participation in the People's War. In A. Karki \& D. Seddon (Eds.), The People's War in Nepal Left Perspectives (p. 495). Adroit Publishers.

Perera-mubarak, K. N. (2013). Positive responses, uneven experiences : intersections of gender , ethnicity , and location in post-tsunami Sri Lanka. Gender, Place \& Culture, 20(5), 664685. https://doi.org/10.1080/0966369X.2012.709828

Rahill, G. J., Joshi, M., \& Hernandez, A. (2016). Adapting an evidence-based intervention for HIV to avail access to testing and risk-reduction counseling for female victims of sexual violence in, 0121(September 2017). https://doi.org/10.1080/09540121.2015.1071773

Regmi, S. (2007). Nepali Women and Their Struggles over Water during Pregnancy. International Feminist Journal of Politics, 9(4), 522-523. https://doi.org/Regmi, Sabrina. 2007. "Nepali Women and Their Struggles over Water during Pregnancy.” International Feminist Journal of Politics, no. December: 522-23.

Ruwanpura, K. N., \& Humphries, J. (2004). Mundane heroines : Conflict, Ethnicity, Gender, and Female Headship in Eastern Sri Lanka, 10(2), 173-2015. https://doi.org/10.1080/1354570042000217766

Saif, K., \& Alia, C. (2017, December 7). Nepal Elections Explained. Aljazeera, p. 1. Kathmandu. Retrieved from https://www.aljazeera.com/indepth/interactive/2017/11/nepal-elections-2017-explained171126103009857.html

Save the Children. (2016). Did the humanitarian response to the Nepal earthquake ensure no one was left behind?, 26.

Standing, K., Parker, S., \& Bista, S. (2016). Grassroots responses to violence against women and girls in post-earthquake Nepal : lessons from the field. Gender \& Development, 24(2), 187204. https://doi.org/10.1080/13552074.2016.1194562

Sthapit, C. W. (2015). Gendered Impacts of the Earthquack and Responses in Nepal. Feminist Studies, 41(3), 682-688.

UNFPA (United Nations Population Fund). (2014). Population Monograph of Nepal. Kathmandu. 
Chapter 7: Conclusion and Discussion 


\subsection{Introduction}

This thesis has examined shifts in gender roles in Nepal during the Maoist war and in the aftermath, including the earthquake that hit the country on 25 April 2015 as it was still recovering from the war. The thesis is an exploration of the ways in which gender roles shift during conflict and disaster and the sustainability of such changes beyond these crises. These processes have been investigated by focusing on the lived experiences of women.

The central question this thesis addresses is: How have women (ex-combatants, noncombatants and earthquake survivors) experienced shifts in their gender roles during the Maoist conflict and the disaster, and have those changes in gender roles been sustained in the aftermath of war and disaster? The thesis is interested in understanding the challenges that women faced after the crisis ended, and how post-conflict and disaster programmes responded to women's needs in the post-conflict and disaster context in Nepal.

The central question is addressed by seeking answers to the following four sub-questions.

1. How have gender roles of women (ex-combatant, non-combatant) changed during the Maoist conflict, and what happened to those changed roles in the aftermath of the war in Nepal?

2. What challenges did women face in their everyday lives in the post-conflict era and how has gender role change shaped women's responses to these challenges?

3. How have the post conflict reintegration policies shaped the process of gender role change and women's everyday challenges?

4. What challenges did women face in the wake of the post-earthquake period and how were these related to their gender position? How did gender roles change in the time of the earthquake in Nepal? 
The research found the following major shifts to women's (ex-combatants, non-combatants, and earthquake survivors) everyday lives:

1. Women experienced changes in gender roles during the conflict and disaster periods that they described in terms of increased gender equality and empowerment (Chapter 3, 4 and 6).

2. Women encountered considerable challenges in the post-war and post disaster settings and found that changes in gender roles were not, or only very partially, sustained after the end of the war (Chapters 3, 4 and 6).

3. Women encountered considerable challenges while accessing post-conflict and disaster recovery and reintegration policy/programmes (Chapters 5 and 6).

4. Post-conflict and post-disaster policies hardly mitigated the challenges. Despite the emphasis on gender mainstreaming, women (particularly ex-combatants and earthquake survivors) experienced multiple forms of exclusions (chapter 4, 5 and 6).

Different categories of women faced different levels of challenges while sustaining their new roles in the post-war period. Women ex-combatants experienced a harder rollback because their war-related roles were not valued in the labour market and the reintegration programming failed to provide them with suitable training and skills. This drove them to depend upon their husbands' income to meet their daily needs. However, the women non-combatants did not face a similar roll back as women ex-combatants. This was mainly because the roles which they performed during the war were 'normal roles' accepted by society such as taking the socioeconomic responsibilities, entering politics, and attending meetings, in contrast to what women ex-combatants performed.

When the earthquake hit, women performed roles which were previously reserved for men. They rescued their families and put their own lives at risk, participated in the debris clearance, guarded the camp sites where they lived temporarily in the time of crisis, took part in funeral rituals, searched for relief and jobs, and interacted with different people. Because the earthquake happened just over three years ago, at this point it remains unclear whether these changes are temporary or permanent. 
Below, I will go deeper into these findings by discussing each sub-question. Before doing so, however, I will briefly situate my research in the broader literature on women and gender role transformation.

This thesis builds on and aims to contribute to the rich global literature about conflict and gender role transformation (Connell 1987; El-Bushra 2003, 2010; Enloe 2004; Cohn 2013; Arostegui 2013; Niner 2011; Jacobson 2013; Grabska 2013; Moosa, Rahmani, and Webster 2013) and, to a lesser degree about gender and disaster (Bradshaw 2001, 2013, 2014; Horton 2012; Enarson and Morrow 1998; Fothergrill 1998). It has been convincingly argued that war might be the process through which women's roles are changed and through which women are empowered (El-Bushra 2003, 2010; Cohn 2013; Arostegui 2013; Niner 2011; Jacobson 2013; Grabska 2013). Similarly, the growing body of literature about disaster has shown how women fare in disaster, where they often play multiple roles, and develop leadership skills in the time of crisis and beyond (Bradshaw 2001, 2013; Cupples 2007; Horton 2012; Enarson and Morrow 1998; Perera-mubarak 2013).

Scholarship in Nepal has acknowledged the reasons why women joined the Maoist war, the ways in which the war impacted women, and women's experience in the peace process (Gautam, Banskota, and Manchanda 2001; Sharma and Prasain 2004; Tamang 2009; Pettigrew and Shneiderman 2004; Parvati 2003; Goswami 2015; Yadav 2016; Shekhawat 2015; Dahal 2015). Other studies about women in the post-earthquake in Nepal includes Standing et al. (2016) on violence against women and girls (VAWG) and Sthapit (2015) on the impact of the earthquake. By focusing on the narratives of women, this thesis provides ethnographic depth that shows how the Maoist war and disaster led to gender role change. It also shows what happens to women's changed role in the aftermath of war and disaster, what challenges women faced after the end of the crisis, and how post-conflict and disaster programmes responded to women's challenges.

The thesis answers the above questions through the following central research question and sub-questions. The central question of this thesis is: How have women (ex-combatants, noncombatants and earthquake survivors) experienced shifts in their gender roles during the Maoist conflict and the disaster, and have those changes in gender roles been sustained in the aftermath of war and disaster? The central research question is answered by following four subquestions. 
Below, I answer each of the sub-questions ending each time with a short discussion of how my findings connect or add to what already exists in the literature.

1) How have gender roles of women (ex-combatant, non-combatant) changed during the Maoist conflict, and what happened to those changed roles in the aftermath of the war in Nepal?

\section{During the War}

The research reveals that the Maoist war (and later the earthquake) offered multiple opportunities for women (ex-combatants, non-combatants, and earthquake survivors) to take on new gender roles. This effect was found most strongly among women ex-combatants. When women joined the war, they took-up highly masculine roles equal to men. For example, they received military training, and participated in military attacks. They were also assigned to important military positions such as platoon commanders, company commanders and section commanders (see Chapters 3 and 4). This was not just an accidental effect. Many women were attracted to the Maoist movement because Maoist ideology strongly emphasised gender equality, women's empowerment, and caste and class equality in their war agenda and messaging.

Women ex-combatants' sense of empowerment was not only due to the experience of gender equality but to the diminishment of caste hierarchy (Chapters 3 and 4). This finding is different from earlier studies which have suggested that Maoist gender ideology was merely rhetorical and did not lead to real and sustained empowerment of women (Tamang 2009, Pettigrew and Shneiderman 2004). The narratives of the Nepali women ex-combatants resonate with the experience of women fighters in Sri Lanka and Latin America (Azmi 2015; Kampwirth, 2002) (see Chapter 4), but is in contrast to Northern Uganda, Sierra Leone and Mozambique, where women and girl fighters were given subordinate military roles (Mackenzie 2009; McKay and Mazurana 2004). Yet, little scholarly attention has been paid to the gender ideology and empowerment.

In the case of women non-combatants, their gender roles also shifted during the war. Whether their husbands were away in the military, had joined the rebels, or were disabled or missing, women's roles were expanded. They began to occupy men's positions in the affairs outside of 
the family. For example, women took up greater economic responsibilities in the labour force, participated in public meetings, entered local politics, operated restaurants, and got involved in the local NGOs programmes (Chapter 3).

The above findings confirm the argument that crisis can provide women with an avenue for economic, political, and social change - and perhaps a kind of change that they would not so easily have experienced in normal, non-war circumstances.

\section{After the War}

In the aftermath of war, women faced different challenges as they tried to sustain their changed gender roles. Although the Maoist conflict shifted women's roles (from the private to the public domain), the patriarchal norms and the social-cultural traditions of the society did not change at the same speed, and in some ways, were even strengthened in the post-war setting. Women ex-combatants found this situation much harder to deal with than other women. After a lengthy period (2007-2012) of disarmament, demobilisation, and reintegration (DDR), they returned with a small sum to set-up a new life. The challenges they faced in rebuilding their lives were partly shared with their male peers. But these challenges were also clearly gendered. Some livelihood options were not available or difficult to obtain for women, and such restrictions drove them back to domestic roles in the kitchen and the household (see Chapter 3 and 5). Another challenge they encountered is to regain trust in the society: some women were stigmatised due to their past actions in the war and were still considered as violent spoilers and killers.

In the case of women non-combatants, the period after the war was more positive compared to the experience of women ex-combatants. They did not experience a similar roll back. Women performed jobs in both the public and private sphere during the insurgency. Through this process they achieved economic empowerment which made them local business women. Women established themselves economically and socially which included the creation of networks in the local market, interaction with diverse groups of consumers, producers and retailers, and have built strong relationships. They were able to maintain their positions even when their husbands returned home in the post-war setting (Chapter 3). These roles appear to have changed family and community perspectives towards women's capacity as workers or wage-earners. On the other hand, men lost their previous role as the primary family 
breadwinner. It is unclear whether women improved economic independence will grow or whether when men have access to opportunity and return to their prior position, women will be pushed back to traditional roles.

The research results describe women's experience of the sexual division of labour and sexual division of power during the war and in the post-war settings (see Chapter 3). This adds a new perspective to the literature on wartime and post-war gender change in Nepal. So far, studies have examined women's mobilisation, and its causes and consequences in the Maoist war (Gautam, Banskota, and Manchanda 2001; Manchanda 2004; Goswami 2015; Yadav 2018; Shekhawat 2015). A number of scholars have also examined gender relationships and women's roles in the conflict (Parvati 2003; Gautam et al. 2001; Sharma and Prasain 2004), but these do not focus on women's experience in the post-war development after 2006. At the same time, the studies that have investigated post-conflict era issues are mainly about peace building, DDR, and the state restructuring (Bhandari 2015; Martin 2012; Subedi 2014).

\section{2) What challenges did women face in their everyday lives in the post-conflict era and how has gender role change shaped women's responses to these challenges?}

The findings illustrate that women retained the ideological aspirations toward equality they had acquired during the war and developed several strategies to circumvent and negotiated/renegotiated the gendered obstacles they faced after the war. For example, a few women ex-combatants revealed that their husbands restricted them from participating in local politics. Similarly, Maoist leaders demotivated them from entering politics by devaluating their war roles. Women also confronted men's occupation of the public roles in the villages and in the market, where local people still hesitated to offer women masculine jobs (Chapter 3, 4, and 5). In response, women renegotiated the roll back of their changed gender roles through taking their demands (such as credit facilities, employment opportunities, health, life skills training, and education access) to the street with protests targeted at the Maoist party and the government (Chapter 4). Likewise, some women formed an association named The Former People's Liberation Army (PLA) Mahila prathisthan (women's organisation). This organisation aims to promote women's voices, particularly those of women ex-combatants (see Chapters 3 and 5).

The next challenge women renegotiated was to get their war time inter-caste marriage socially approved. Some of the upper-caste women ex-combatants married lower-caste men, and a few 
lower-caste women married upper-caste men. Lower-caste women marrying upper-caste men encountered more exclusions, including rejection by the men's family. However, women fought back against this exclusion by relocating to an area where they felt their inter-caste marriages were respected, staying among war peers, and/or moving to multicultural cities (see Chapters 3, and 4). Likewise, unmarried women ex-combatants renegotiated their post-war position by attempting to find marriage partners and resisted the idea that they were not suitable wives or proper women.

In case of women non-combatants, they also achieved empowerment while surviving the conflict, and this helped them to renegotiate their situation in post-war settings. For example, a widow's family hesitated to provide her husband's property share, but she reported this to the legal office and fought for her property rights (Chapter 3). Women non-combatants were also affiliated with local NGOs, legal organisations, and grassroots women's groups, and continued to maintain economic independence. Both ex-combatant and non-combatant women encountered institutionalised inequality that hampered their exercise of gender equality.

The findings of this research demonstrate that the change in gender roles offered women a sense of empowerment which crossed caste lines. For instance, both lower- and upper-caste women (combatants and non-combatants) shared the experience of escaping the previous limitations of the patriarchal structure and were able to contrast their lives before and after the insurgency (Chapters 3 and 4). My study results also show that even upper-caste women excombatants faced similar or sometimes worse discrimination, because they had to follow certain restrictive spiritual rituals (like maintaining purity) which is different from the lower caste. For example, when upper-caste women ex-combatants married lower-caste men, they were completely discarded by their family, and lacked support after returning from the war. This finding adds complexity to the discussion of caste, because most existing literature focuses on lower-caste women's issues (Pant and Standing 2011; Gautam, Banskota, and Manchanda 2001; Shakya 2003). 


\section{3) How have the post conflict reintegration policies shaped the process of gender role change and women's everyday challenges?}

My study found that even after gender mainstreaming in the post-war policy/programme, women at the grassroots levels did not benefit from this process. Women ex-combatants in particular experienced a step backwards; as they returned to their earlier roles and private lives, they lost some of the power which they had enjoyed in war because the country's post-conflict programming failed to integrate women ex-combatants' needs. For example, women excombatants had to compete with women who had better education and skills, and thus they were unable to make headway in such competitions. Further, organisations were biased towards combatants when offering skills programmes. The training providers grouped 'combatants' under 'conflict-affected' category (together with war widows or other conflict victims). Priorities were often given to the war widows or other conflict-affected households and combatants were prevented from taking part in such skills programmes. Also, training venues were located very far from homes and lacked child care facilities which made it difficult for women to travel with an infant and therefore their admission was not possible (Chapter 3 and $5)$.

In addition, during reintegration programming phase women felt marginalised because the DDR planners and implementers lacked understanding about women ex-combatant's strategic demands. For instance, among the three reintegration programme options open to former combatants, women were obliged to choose 'voluntary retirement cash compensation' as they did not qualify for other reintegration options because they did not have proper education, skills, and training. This effected women's private and public decisions in the post-war regime (see Chapter 4, and 5). Likewise, when women combined their 'voluntary retirement cash compensation' with their husbands to buy a property, that property then moved to the husband's ownership and women ended up losing their share.

The study findings demonstrate that family reception and community played a role in the reintegration. For example, women who maintained reciprocal relations during war with their family faced a smoother reintegration. In contrast, women ex-combatants from non-Maoist family backgrounds, many of whom entered the Maoist against family agreement, were unwelcome after returning from the war. Consequently, these women faced social isolation and had to rely almost exclusively on the networks of war peers (chapter 5). 
My study reveals that Nepal's disarmament process was gender inclusive in the way it was set up. It used the unconventional disarmament method of 'voluntary' and 'collective weapon' submission. This approach was significant because it opened up space for the inclusion of larger numbers of women ex-combatants in the DDR process. Even women without weapons were considered as Maoist combatants, based on an interview in which they described their roles in the insurgency. This contrasts with DDR processes described for some African countries which used the principle of 'one gun, one combatant' (Mackenzie 2009; McKay and Mazurana 2004).

\section{What challenges did women face in the wake of the post-earthquake period and how were these related to their gender position? How did gender roles change in the time of the earthquake in Nepal?}

This study's findings show that women faced a range of challenges while surviving an earthquake that encouraged a shift in their gender roles. When the earthquake hit, women acted immediately by rescuing their family members, took care of their family and households, and immediately searched for food, accommodation, and money. Women sought additional income opportunities when the earthquake destroyed their husband's business (such as carpentry shops, carving statues, or farming), they guarded their children and property in emergency tents, and attended the funerals on the Ghat (bank of river where bodies are buried) (see Chapter 6). All of these were men's roles in the pre-earthquake period.

Other shifts arose from the earthquake. For example, women survivors stayed together in the tent with other women and men of all castes, including during their time of menstruation. Against the normal cultural expectations of seclusion during menstrual periods, women were allowed to stay together in the camps, and to touch food, cook meals, and collect water. As a result, caste and gender-based discrimination disappeared (temporarily) into the background (see more Chapter 6). It is not clear whether these practices will be sustained in the long-term.

The most unexpected challenge women face is new debt produced by the disaster. In the prewar period many women had houses, no major medical problems, and access to school for their children. But when the earthquake collapsed their houses, they were displaced and stayed in a rented house, had to pay for extra medical expenses created by the crisis, and looked for food 
and accommodation. They incurred expenses because of the need to travel to find work. Temporarily women fulfilled emergency needs by borrowing money from the relatives or friends or local money landers and some of them used their past savings. At this point, it is uncertain how women are going to repay this new debt in the future.

When women lack citizenship certificates, or other identity papers that were required for accessing relief, they faced a range of challenges. For example, one of the migrant women and her child slept hungry when she did not receive food relief because she was unable to provide the required document to prove her identity. Another migrant woman (whose husband lived abroad) was rejected by the bank when she applied for a loan to start a business because the bank lacked assurance that she could repay the loan in her husband's absence. This evidence questions the commitment to the gender mainstreaming policy of Nepal (see Chapter 5 and 6).

There are many policy responses to gender equality in Nepal. Currently, the state reserves 33 percent of seats for women in the constitutional assembly (Nepal Institute for Policy Studies, 2013; Pant \& Standing, 2011), yet it is questionable whether these women represent grassroots women's voices. Even though the earthquake relief programme does not intend to discriminate against women, the practice of presenting documents to access aid excludes them because women are more likely to lack official documents. The country's discriminatory citizenship law backs up such practices; women in Nepal can only obtain citizenship under the name of their father or husband. If the men deny their relationship to women, then those women will remain stateless (see Chapter 6). Women earthquake survivors also lack proper education/skills and were unable to find post-earthquake jobs because they had to compete with elite women. Similar experiences were faced by women ex-combatants because they could not qualify for women's quotas in the jobs where education is required (Chapter 6). Even though gender policies can bring about change, it is important to monitor if and how improvements in daily gender relationships lead to longer-term or more fundamental changes.

The research on women earthquake survivors was conducted for five months immediately after the disaster in May to September 2015, it does not present information from the period after that. There are now many post-disaster reconstruction programmes being implemented and these might offer a different perspective. 


\subsection{General Reflection on this Thesis}

In the process of the Maoist war, women ex-combatants experienced strong changes in their roles because in the military they practiced equal division of labour, power and position. Some women even lead the men in combat. However, in the aftermath of war, they faced many challenges in sustaining their roles. On the one hand, the patriarchal pattern of society remained unchanged from before the war and therefore their war roles were mostly rejected. Moreover, gender equal policies and gender quotas do not directly benefit them; women had to compete with those who had better education and skills. Women also struggled to get access to the local politics as their war roles were considered limited to the Maoist military service and were not accepted as political experience. But the sense of empowerment they achieved from the war persists, and even after reverting to their previous roles, they continue to push back against their current situation.

Women non-combatants took sole responsibility of the household after their husbands died or became rebels or displaced people. In the search for survival during the war, these women faced many challenges but managed to develop entrepreneurship and leadership skills. Therefore, gender roles, which were previously confined within households, were changed to the public sphere when these women started operating restaurants and tailoring shops, affiliating with NGOs, and participating in training and accessing credit from the banks. These women do not have to rely on men to fulfill their everyday needs. Also, the data shows that the slow post-war recovery process and high unemployment has changed the family structure and gender relationships. Now, both men and women migrate in search of livelihood options. When husbands migrate outside the country, the wives stay in the cities for children's schooling (see Chapter 6). leaving the parents-in-law in the village. At the same time, when women are migrating abroad men are gradually taking on the women's roles. Furthermore, the traditional ways of doing men's jobs and women's jobs have also been interrupted and fused in the postwar era. In the pre-war situation, operating restaurants was mainly men's work and now both are performing it. In some cases, it is accepted as women's work. Likewise, before the war, women's migration was a big taboo and was restricted to married women. But lack of jobs in the country (and men losing income), and the high demand for women as carers abroad means that women are slowly taking leadership in migration. Estimates suggests that in 2011, more than 237,000 Nepali women migrated for employment which is about 12 percent of the total number of migrants (Peskin 2016). 
Women earthquake survivors also experienced a shift in their roles while saving and taking care of their family and looking for the means of livelihood when the men lost income. While going through this experience women became very conscious of the limitations of their usual roles and developed ambitions to change, partly instigated by the interaction with other displaced women of different backgrounds. It is uncertain how these women are going to fight to sustain their new roles in the postwar/post disaster regime as they face ongoing patriarchal systems, centralised gender policies, domination by elite women of the available opportunities, and grassroots women's own situation.

Although the post-crisis provided prospects for new development, opportunities, and change in the women's situation, however, this process requires revisiting due to centralised policy system which is controlled by some elite groups. At the same time, in society at large, the division of labour and power continues to rely on the imbedded mindsets, cultural patterns and social orders. These structures might change but at very slow pace: war and disaster alone cannot change these systems.

\subsection{Limitations and Future Implications}

In this study, women ex-combatants from other districts (Makwanpur, Nawalparasi, Rupandehi) were also contacted but they refused to be interviewed. Thus, this research was conducted in Chitwan district with women ex-combatants and women non-combatants in both Chitwan and Kathmandu district. The research might have produced additional perspectives if women ex-combatants from other regions had also been involved. Combatants living in the eastern or hilly regions might have different experiences due to different cultures, job options, and their political environment. Future research is required to see how the challenges women ex-combatants faced were different or similar by location, in the reintegration period.

This research captures the period up to February 2015. Afterwards, there have been significant political shifts in Nepal, including the release of the new constitution in September 2015, the fractioning of the Maoist party and the gradual loss of Maoist political power, state restructuring, and the recent local election of 2017. Therefore, more research is required to examine where gender equality and women's empowerment stand in the current constitution, how women's issues have fared in the new gender policy and framework to understand the effect of major socio-political change in gender roles and relationships in New Nepal. 
Finally, Chapter 6 captured the five-month period in the immediate aftermath of earthquake in Bugamati area. It has been more than 3 years since the earthquake happened (April 2015- July 2018). Until recently, there were many interventions taking place in the post-recovery phase. More contributions are required covering more districts examining what happens when disaster collides with post-conflict transitions, how social patterns, gender orders and gender systems change and operate, and how sustainability is possible in the post-disaster period.

\subsection{Policy Recommendations and Practice}

In terms of policy recommendation, the thesis has made a significant contribution to the literature on women's empowerment and gender-role change over the various transition periods (in the conflict, post-conflict context and disaster timing). This thesis concludes that even though the process of war and disaster offers women room to maneuver for change or stretch their roles, such change is not sustainable because larger societal traditions and cultural norms changes more slowly. Based on the findings of this study, this section provides four insights for future policy and practice.

A bottom-up approach to women's empowerment should be a policy consideration and instituted in all practices. Nepal has made some significant achievements toward gender equality, such as mandating 33\% representation of women in the constitution assembly. But again, this does not benefit women at the grassroots level because these positions are mostly occupied by women at the central levels or from the privileged categories. In the light of the findings of this study, a bottom-up empowerment approach would include representation of women from the grassroots. Also, it is important to analyse the differences in women's positions and let women identify their own needs, plan the programmes most suitable for women, and work to make such programmes sustainable.

Extensive gender-equality sensitising and awareness building. Even today gender is considered as only a women's issue. But gender as an identity exists even beyond the binary categories of women and men. Therefore, including women and other genders is required to maintain a gender equal society. Also, there is an assumption that maintaining gender equality is only the job of the State or NGOs yet practicing gender equality starts from home and the way we deal with our everyday lives. If society is gender equal, it benefits everyone and not 
only women. The results of this thesis also reveal that some gender inequality is reproduced in society due to patriarchal norms and traditional systems. Therefore, through such policy implementation at the state, regional and local levels (family and community) support to challenge some of the prejudices could be encouraged.

Inclusive post-reintegration policy programming. Although the DDR process has been completed and ex-combatants have returned to mainstream society, in reintegration they are facing many challenges including stigmatisation. This is because of the gender bias in reintegration programming which includes lack of effective reconciliation programmes to connect the combatants with their community. Therefore, more inclusive post-reintegration programming is required to support long-term reintegration of combatants.

Looking beyond gender-mainstreaming. The thesis reveals that women face insecurity in a time of disaster because of gender, pregnancy, breastfeeding status, widowhood and migration status. Therefore, it is urgent to move beyond gender mainstreaming to an intersectional approach which takes gender differences amongst women seriously and to reduce women's challenges in the time of disasters, conflict and post-conflict periods. 


\subsection{References}

Arostegui, J. (2013). Gender, conflict, and peace-building: how conflict can catalyse positive change for women. Gender \& Development, 21(January 2015), 533-549. https://doi.org/10.1080/13552074.2013.846624

Azmi, F. (2015). IWantMyWings Back to Fly in a New Sky: Stories of Female Ex-LTTE Combatants in Post-War Sri Lanka Fazeeha. In S. Shekhawat (Ed.), Female Combatants in Conflict and Peace: Challenging Gender in Violence and Post-Conflict Reintegration (pp. 200-2015). London: Palgrave Macmillan.

Bhandari, C. (2015). The Reintegration of Maoist Ex-Combatants in Nepal. Economic \& Political Weekly, L(9), 63-68.

Bradshaw, S. (2001). Reconstructing Roles and Relations: Women's Participation in Reconstruction in Post-Mitch Nicaragua. Gender \& Development, 9(3), 79-87. https://doi.org/10.1080/00223891.2011.608754

Bradshaw, S. (2013). Gender, Development and Disasters. UK: Edward Elgar.

Bradshaw, S. (2014). Engendering development and disasters. Disasters, 39, 54-75. Cohn, C. (2013). Women\&Wars (First). Cambridge: Polity Press.

El-bushra, J. (2010). Development in Practice Fused in combat: Gender relations and armed conflict Fused in combat : gender relations and armed conflict. Development in Practice, (February 2012), 37-41. https://doi.org/10.1080/0961452032000073215

El-Bushra, J. (2003). Fused in combat: Gender relations and armed conflict. Development in Practice, 13(2-3), 252-265. https://doi.org/10.1080/09614520302941

Fothergrill, A. (1998). The Neglect of Gender in Disaster Work: A Overview of the Literature. In E. Enarson \& B. H. Morrow (Eds.), The Gendered Terrain of Disaster: through women's eyes (pp. 11-25). London: Praeger.

Gautam, S., Banskota, A., \& Manchanda, R. (2001). Where There Are No Men Women In The Maoist Insurgency in Nepal. In D. Thapa (Ed.), Understanding the Maoist Movement in Nepal (First, pp. 93-124). Kathmandu: Martin Chautari.

Goswami, R. (2015). UNSCR 1325 and Female Ex-Combatants-Case Study of the Moiast Women of Nepal. New York.

Grabska, K. (2013). The return of displaced Nuer in Southern Sudan: Women becoming men? Development and Change, 44(5), 1135-1157. https://doi.org/10.1111/dech.12051 Jacobson, R. (2013). Women “After” Wars. In C. Cohn (Ed.), Women and Wars (pp. 215241). USA: Polity Press. 
Kampwirth, K. (2002). Women and Guerilla Movements: Nicaragua, El Salvador, Chiapas, Cuba (First). University Park, Penn: Penn State University.

Manchanda, R. (2004). Maoist Insurgency in Nepal: Radicalizing Gendered Narratives. Cultural Dynamics, 16, 237-258. https://doi.org/10.1177/0921374004047750

Martin, I. (2012). The Unitee Nations and Support to Nepal's Peace Process: The Role of the UN Mission in Nepal. In von S. Einsiedel, M. D. Malone, \& S. Pradhan (Eds.), Nepal in Transition From People;s war to Fragile Peace (p. 383). Cambride University Press.

Moosa, Z., Rahmani, M., \& Webster, L. (2013). From the private to the public sphere : new research on women' s participation in peace- building From the private to the public sphere : new research on women 's participation in. Gender \& Development, 21(3), 453472. https://doi.org/10.1080/13552074.2013.846585

Nepal Institute for Policy Studies. (2013). Nepal's Peace Process : A Brief Overview Nepal Institute for Policy Studies ( NIPS ). Policy Paper (Vol. 8). Retrieved from http://www.nipsnepal.org/pictures/publication/Z5C_Nepal's_Peace_Process_A_Brief_ Overview_English.pdf

Niner, S. (2011). Hakat Klot, Narrow Steps. International Feminist Journal of Politics, 13(3), 413-435. https://doi.org/10.1080/14616742.2011.587371

Pant, B., \& Standing, K. (2011). Citizenship rights and women's roles in development in postconflict Nepal. Gender \& Development, 19(3), 409-421. https://doi.org/10.1080/13552074.2011.625656

Parvati, C. (2003). Women's Participation in the People's War. In A. Karki \& D. Seddon (Eds.), The People's War in Nepal Left Perspectives (pp. 165-182). New Delhi: Adroit Publishers.

Perera-mubarak, K. N. (2013). Positive responses, uneven experiences : intersections of gender, ethnicity, and location in post-tsunami Sri Lanka. Gender, Place \& Culture, 20(5), 664-685. https://doi.org/10.1080/0966369X.2012.709828

Peskin, A. (2016). Out of Nepal: Women's Labor Migration. Retrieved September 12, 2018, from https://wafmag.org/2016/06/nepal-womens-labor-migration/

Pettigrew, J., \& Shneiderman, S. (2004a). Pettigrew , J. \& S. Shneiderman (2004) Women and the Maobadi: Ideology and Agency in Nepal's Maoist Movement” in, 17(January), 1929.

Pettigrew, J., \& Shneiderman, S. (2004b). Women and the Maobadi: Ideology and Agency in Nepal's Maoist Movement. Himal Southasian, 17(January), 19-29.

Ruwanpura, K. N., \& Humphries, J. (2004). Mundane heroines : Conflict, Ethnicity, Gender 
, and Female Headship in Eastern Sri Lanka, 10 (2), 173-2015.

https://doi.org/10.1080/1354570042000217766

Shakya, S. (2003). The Maoist Movement in Nepal: An Analysis from the Women's Perspective. In D. S. Karki Arjun (Ed.), In The People's War in Nepal Left Perspectives (pp. 375-404).

Sharma, M., \& Prasain, D. (2004). “Gendered Dimensions of the People's War: Some Reflections on the Experiences of Rural Women. In M. Hutt (Ed.), Himalayan People's War: Nepal's Maoist Rebellion (pp. 152-64). Bloomington: Indiana University Press.

Shekhawat, S. (2015). Female combatants in conflict and peace: Challenging gender in violence and post-conflict reintegration. Female Combatants in Conflict and Peace: Challenging Gender in Violence and Post-Conflict Reintegration. London: Palgrave Macmillan. https://doi.org/10.1057/9781137516565

Standing, K., Parker, S., \& Bista, S. (2016). Grassroots responses to violence against women and girls in post-earthquake Nepal : lessons from the field. Gender \& Development, 24(2), 187-204. https://doi.org/10.1080/13552074.2016.1194562

Sthapit, C. W. (2015). Gendered Impacts of the Earthquack and Responses in Nepal. Feminist Studies, 41(3), 682-688.

Subedi, D. B. (2014). World development. World Development (Vol. 59). Pergamon Press.

Tamang, S. (2009). 91 the politics of conflict and difference or the difference of conflict in politics : the women's movement in Nepal. Feminist Review, 61-80. https://doi.org/0141-7789/09 


\section{Summary}

Nepal suffered from the civil conflict from 1996 to 2006 as the Communist party of Nepal (socalled Maoist) sought to end the monarchical system that had been in place for 240 years and establish a People's Republic. The Maoist-party ideology was highly focused upon the structural transformation of the country and had a strong message about women's empowerment. The conflict brought a dramatic shift in the social, economic, and the political situation of Nepal. In November 2006, the peace agreement was signed, the country then started the post-conflict reconstruction process, such as writing a new constitution, constitution assembly election, state restructuring, and the policy formation.

The Maoist conflict produced multiple gendered effects upon women's everyday lives. One category of women joined as Maoist combatants in search of equality and empowerment and performed roles equal to men in the war. Another category of women stayed behind when the men fled from the war to the cities or neighbouring countries, and their husbands, fathers or sons were killed, or became rebels or disappeared in the war. Women non-combatants experienced a situation where men's work shifted onto their shoulders and they performed dual roles; at home and outside.

After the earthquake happened on 25 April 2015 in Nepal, women were impacted in a different way. When men were killed or became disabled, were away, or lost income in the earthquake, women took over men's roles and responsibilities, such as rescued their family members, searched for the food, accommodation, financial support, jobs, health care, including took care of the children and elderly people. At the same time, women were also involved in a multiple role during post-earthquake settings.

The conflict/post-conflict/disaster period produces gendered effects; thus, gender analysis becomes fundamental during this time to understand how women and men deal with the rapid gender role change in the context of crisis and its aftermath, when there is a certain return to the normal situation.

This thesis is about women and changing gender roles in Nepal. The study traces the gendered effects of the Maoist war and the earthquake on women's everyday lives. It examines how women experience the impact of the Maoist war and the post-conflict era in relation to shifting 
gender roles, responsibilities, challenges, and new openings. The thesis then asks similar questions about women affected by the earthquake, that happened while the country was still struggling with post-conflict issues.

Chapter 1 presents the introduction, which offers an overview of the main concern of the thesis and the theoretical perspectives (the sexual division of labour and power, ideology of gender, structural factors, and the role of the policy) that inform it. Chapter 2 outlines the methodology (in-depth interview, focuses group discussion, participant observation, and key informant interview) applied to conduct this study.

Chapter 3 examined how the Maoist conflict in Nepal affected women ex-combatants and noncombatants, looking at changes in gender roles during and after the conflict particularly from the standpoint of livelihood challenges in the post-war period. Major findings indicate that changing gender roles largely depend upon everyday practice of sexual division of labour and power as it evolved during and after the conflict. It also shows that the conflict produced different and contradictory effects on both categories of women who experienced shifts in gender roles. In post-war settings, these changes were partly reversed, and especially excombatant women faced severe livelihood challenges and returned to traditional gender roles.

Chapter 4 investigated how the Maoist armed conflict in Nepal was a struggle for the emancipation of women and it particularly looked at how women ex-combatants were engaged with ideas of gender equality and women's empowerment during the Maoist war and afterwards. It further explores what happens to women's ideological drive as gender roles 'shift back' after the war. The results demonstrate that in the Maoist war women ex-combatants were strongly committed to the Maoist gender ideology and experienced empowerment through this process, as they adopted non-traditional roles and crossed gender as well as caste lines. However, in the post-war, they felt ambivalent empowerment because there was a lack of commitment from the Maoist party to issues of gender equality and at the same time the patriarchal structures continued intact and, in some ways, even strengthened, and women faced multiple exclusions. 
Chapter 5 looked at how women ex-combatants experienced the reintegration process in the aftermath of war. The study found that the reintegration programming of Nepal lack gender framework due to which woman encountered a range of challenges in the post-war period. Mainly, the challenges were two-fold: At the societal level; they struggled to gain recognition, and at the family level they negotiated/renegotiated to rebuild relationships and safety-nets.

Chapter 6 investigated what challenges women faced in the wake of the earthquake and how these were related to their gender position. It asks how gender roles changed in relation to the earthquake in Nepal. Findings illustrate that different categories of women faced the effects of earthquake differently, especially with regards to the intersectionality of gender and migration and family composition. The earthquake provided women a window of opportunity to change gender roles. On the other hand, women encountered great difficulties in addressing their everyday needs and experienced gender-based exclusion.

Chapter 7 synthesises the outcomes of the four substantive chapters, discusses the findings, and offers four recommendations for policy implications. 


\section{Samenvatting}

De Maoistische opstand (1996-2006) betekende een dramatische verschuiving in de sociale en politieke situatie in Nepal. De Communistische partij van Nepal (beter bekend als 'de Maoisten') had als doel de 240 jaar oude monarchie te beëindigen en in plaats daarvan een Volksrepubliek te vestigen. De ideologie van de Maoistische partij was gericht op structurele veranderingen in het land en behelsde ook een belangrijke boodschap rondom de empowerment van vrouwen. In November 2006 werd de vrede getekend waarna het land een proces van wederopbouw inging. Dit betrof onder meer een grondwetshervorming en de vorming van een constitutionele assemblee, de herinrichting van de staat, en ook nieuw beleid op gendergelijkheid en sociale inclusie.

Het conflict had uiteenlopende gevolgen voor het leven van vrouwen in Nepal. Eén categorie vrouwen sloot zich aan bij de Maoistische strijd waar zij gelijkwaardigheid en empowerment hoopten te vinden en dezelfde rollen vervulden als mannen. Een andere categorie vrouwen bleef alleen achter toen hun mannen de oorlog ontvluchtten en naar de stad of naar buurlanden trokken, of toen zij hun mannen, vaders of zonen moesten missen door dood of verdwijning of juist doordat deze zich aansloten bij de opstand. Deze vrouwen kregen extra lasten op hun schouders: zij deden nu ook het werk van de mannen naast hun bestaande taken in de verzorging van hun gezin en andere familieleden, en hun verantwoordelijkheden in de lokale gemeenschap.

Ook de aardbeving die Nepal trof op 25 April 2015, had grote gevolgen voor het leven van vrouwen, met name wanneer hun mannen het leven verloren of gehandicapt raakten, hun bron van inkomsten verloren of moesten migreren. Vrouwen namen dan de verantwoordelijkheden en rollen van mannen op zich: zij brachten hun gezin in veiligheid, zorgden voor de kinderen en ouderen, zochten naar voedsel, een verblijfplaats, geld, werk, en gezondheidszorg. Na de aardbeving kwamen veel humanitaire hulpacties op gang, zowel lokaal als internationaal, en ook daarin speelden vrouwen een grote rol.

De ervaringen van vrouwen tijdens het conflict, in de naoorlogse ontwikkelingen en bij de aardbeving vertonen een vergelijkbare gender dynamiek. Zowel het conflict als de aardbeving geven inzicht in hoe vrouwen omgaan met de snelle veranderingen in de rolverdeling tussen 
mannen en vrouwen, die zich voordoet tijdens de crisis maar ook daarna wanneer de situatie weer normaliseert.

Deze scriptie behandelt vrouwen en veranderende gender rollen in Nepal. De studie brengt de gevolgen van de Maoistische opstand en de aardbeving voor vrouwen in beeld vanuit een gender perspectief. De studie documenteert hoe vrouwen de verschuivingen in de rolverdeling tussen mannen en vrouwen hebben ervaren tijdens en na de oorlog en welke uitdagingen en nieuwe mogelijkheden vrouwen ondervonden. Vervolgens worden vergelijkbare vragen gesteld over de ervaringen van vrouwen tijdens en na de aardbeving, die het land trof terwijl het nog volop bezig was te herstellen van de gevolgen van de oorlog.

Hoofdstuk 1 bevat de introductie en geeft een overzicht van de belangrijkste thema's en theoretische perspectieven in deze thesis (de verdeling van arbeid en macht tussen de sexen, gender ideologie, structurele factoren in genderverhoudingen, en de rol van beleid). Hoofdstuk 2 gaat in op de methodologie van het onderzoek (diepte-interviews, focus groep discussies, participerende observatie, en interviews met sleutel informanten).

Hoofdstuk 3 beschrijft welke gevolgen de Maoistische opstand in Nepal heeft gehad voor vrouwen, zowel zij die toetraden tot de gewapende opstand, als zij die buiten de strijd bleven. Het hoofdstuk gaat in op de veranderingen in gender rollen zoals die zich tijdens en na het conflict voltrokken, met specifieke aandacht voor de moeilijkheden die vrouwen ondervonden om in hun levensonderhoud te kunnen voorzien. De studie vindt dat gender rollen veranderen als de alledaagse verdeling van arbeid en macht tussen mannen en vrouwen verschuift, zowel tijdens als na de oorlog. De studie laat ook zien dat het conflict verschillende en deels tegengestelde effecten heeft gehad op de verschillende categorieën van vrouwen. $\mathrm{Na}$ de oorlog hebben met name voormalige strijdsters grote moeilijkheden ondervonden om in hun levensonderhoud te voorzien en keerden zij noodgedwongen terug naar een meer traditionele rolverdeling.

Hoofdstuk 4 onderzoekt hoe de Maostische gewapende opstand ook een strijd was voor de emancipatie van vrouwen. Het hoofdstuk toont wat gelijkheid tussen mannen en vrouwen betekende voor strijdsters en hoe zij zochten naar empowerment. Het hoofdstuk gaat vervolgens na wat er gebeurt met de ideologische motivatie van vrouwen wanneer na de oorlog de rolverdeling weer traditioneler wordt. Het onderzoek laat zien dat de voormalig strijdsters 
zich sterk verbonden voelden met de gender ideologie van de Maoisten en tijdens de jaren van oorlog empowerment hebben ervaren doordat zij traditionele rolpatronen langs gender en langs kaste-lijnen konden doorbreken. $\mathrm{Na}$ de oorlog was deze empowerment echter minder eenduidig. In de maatschappij waar de ex-strijdsters naar terug keerden, waren patriarchale structuren in tact gebleven en in sommige gevallen zelfs versterkt. In de na-oorlogse context werd minder waarde toegekend aan de rollen die vrouwen tijdens de oorlog hadden gespeeld en de Maoistische partijleiding liet na zich sterk te maken voor vrouwenrechten op national niveau.

Hoofdstuk 5 beschrijft hoe ex-strijdsters het reïntegratieproces hebben ervaren en hoe zij hun leven in de naoorlogse periode hebben proberen vorm te geven. Het laat zien dat deze vrouwen meerdere vormen van marginalisering ondergingen. Deze studie stelt vast dat het reïntegratieproces vooral toegesneden was op de mannelijke strijders. Een gender-beleid was afwezig. Vrouwen ervoeren meerdere problemen na de oorlog. Op het niveau van de samenleving kostte het hen veel moeite enige mate van erkenning te krijgen. Op het niveau van hun families moesten zij de banden opnieuw vorm en inhoud geven.

Hoofdstuk 6 richt de aandacht op de ervaringen van vrouwen na de aardbeving en onderzoekt hoe deze te maken hadden met hun positie als vrouw. De vraag in dit hoofdstuk is hoe gender rollen veranderden door deze ramp. De bevindingen illustreren dat verschillende categorieën van vrouwen de gevolgen van de aardbeving anders beleefden, vooral afhankelijk van de familiesamenstelling en eventuele migratie. De aardbeving bood vrouwen een opening om gender rollen te veranderen. Tegelijkertijd echter, hadden vrouwen grote moeite om in hun alledaagse behoeften te voorzien en liepen ze herhaaldelijk op tegen uitsluiting op basis van hun vrouw-zijn.

Hoofstuk 7 tenslotte vat de bevindingen van de vier empirische hoofdstukken samen en plaatst deze in een bredere discussie over gender en verandering. Ook doet het enkele beleidsaanbevelingen op basis van het onderzoek. 


\section{Acknowledgements of Financial Support}

The research described in this thesis was financially supported by Nuffic The Dutch Organization for International Studies/ Netherlands Fellowship Program (NFP). 